\title{
Nonindustrial private landowner's characteristics and their forest management decisions
}

\author{
Sudiksha Joshi \\ West Virginia University
}

Follow this and additional works at: https://researchrepository.wvu.edu/etd

\section{Recommended Citation}

Joshi, Sudiksha, "Nonindustrial private landowner's characteristics and their forest management decisions" (2007). Graduate Theses, Dissertations, and Problem Reports. 4309.

https://researchrepository.wvu.edu/etd/4309

This Thesis is protected by copyright and/or related rights. It has been brought to you by the The Research Repository @ WVU with permission from the rights-holder(s). You are free to use this Thesis in any way that is permitted by the copyright and related rights legislation that applies to your use. For other uses you must obtain permission from the rights-holder(s) directly, unless additional rights are indicated by a Creative Commons license in the record and/ or on the work itself. This Thesis has been accepted for inclusion in WVU Graduate Theses, Dissertations, and Problem Reports collection by an authorized administrator of The Research Repository @ WVU. For more information, please contact researchrepository@mail.wvu.edu. 


\title{
NONINDUSTRIAL PRIVATE LANDOWNER'S CHARACTERISTICS AND THEIR FOREST MANAGEMENT DECISIONS
}

\author{
Sudiksha Joshi \\ Thesis Submitted to the College of Agriculture, Forestry and Consumer Sciences \\ at West Virginia University \\ in partial fulfillment of the requirements \\ for the degree of \\ Master of Science in \\ Forest Resources Management \\ Kathryn G. Arano, Ph.D., Chair \\ Alan R. Collins, Ph.D. \\ David W. McGill, Ph.D. \\ Stuart Moss, M.S., M.B.A \\ Davis College of Agriculture Forestry and Consumer Sciences \\ Division of Forestry and Natural Resources \\ Morgantown, West Virginia \\ 2007
}

Keywords: NIPF landowners, forest management activities, logistic regression 


\title{
ABSTRACT \\ Nonindustrial Private Landowner's Characteristics and Their Forest Management Decisions
}

\author{
Sudiksha Joshi
}

Private forest landowners own the largest share of the forest land in the United States. Future timber supply requires forest management and investment by these private forest landowners. Since private forest landowners are diverse, understanding the factors affecting the forest management decisions of these individuals is important. Two analyses are presented in this study to characterize the forest management decisions of West Virginia NIPF landowners and to understand their forest management decisions. The data for the study was collected from a mail survey conducted in August 2005 to 2100 landowners in West Virginia. The survey resulted in 244 useful responses, a $20 \%$ response rate.

The first analysis characterized West Virginia's NIPF landowners. NIPF landowners were mostly small forestland holders with a median forest size of 43 acres. Aesthetic enjoyment and place of residence were the two most important reasons for owning their forestland. Approximately $97 \%$ of the forestland was owned by $7 \%$ of landowners for whom timber sale was the primary reason for owning the forestland. The majority of the landowners managed their land on their own and only $12 \%$ of the landowners had a written forest management plan. Though less than $13 \%$ of the landowners were engaged in any type of forest management activities (e.g., timber harvest, tree planting, fertilization, road construction, survey, thinning, timber stand improvement, wildlife habitat improvement, etc.) in 2004, 59\% of the landowners had been engaged in some type of forest management activity in the past. Only $21 \%$ of the landowners had harvested any timber from 2000 to 2004. Landowners’ participation in educational and forestry assistance/incentive programs has been minimal.

The second analysis employed logistic regression, a limited dependent variable model, to examine the factors affecting the decision of landowners to engage in 1) timber harvest, 2) silvicultural activities (tree planting, fertilization, herbicide application, grapevine control, thinning, and timber stand improvement), 3) property management activities (road construction, road maintenance, access control, and survey/boundary maintenance), and 4) wildlife habitat improvement and recreation improvement. The independent variables examined were landowner characteristics (i.e., age, education, occupation, income), ownership characteristics (size of the landholding, distance of the nearest forest parcel from the place of residence, year of first parcel acquisition, mode of acquisition), and management characteristics (objectives, who manages the forestland, presence of a written forest management plan). Results showed that landowner, ownership and management characteristics of the NIPF landowners are influential factors in determining their involvement in forest management activities. 


\section{DEDICATION}

I would like to dedicate this thesis to the five most important people in my life. I dedicate my work to my mother, Ms. Shakuntala Joshi (Rai) for her unconditional love and support and for her undying enthusiasm towards life. There will always be a void in my life

without you. I would then like to dedicate it to my father, Mr. Khagendra Bahadur Joshi and for his unconditional love, support, and for instilling that never say no attitude. You two are the reason behind the person I am. I would also like to dedicate this thesis to my younger sister Shraddha Joshi who sometimes seems like an older sister to me with all her wisdom and love and to my younger brother Susan Bahadur Joshi, a shining ball of joy. Finally, I would also dedicate this thesis to Mr. Ishwar Dhami who has been my toughest critic but also a constant inspiration. 


\section{ACKNOWLEDGEMENT}

I could not have completed this thesis in its present state by myself. So I would like to take this space to express my gratitude to all those who have made writing this thesis possible.

First and foremost I would like to express my sincere gratitude to my Advisor Dr. Kathryn G. Arano. I would not be here in the first place if you hadn’t had the faith in me. I am indebted by your patience in understanding me and for all your time with constructive criticism and encouragement.

I would also my like to thank Dr. Alan R. Collins, my committee member for the time and patience to deal with my questions and confusions. I have learnt a lot from your classes that I attended and your constant feedback in improving my research.

I also owe my thanks to Dr. David W. McGill, my committee member for his constant queries about my research, encouragement and for my only trip to meet with the NIPF landowners of West Virginia.

I would also like to thank Professor Stuart Moss, my committee member for his important insights whenever I presented my issues.

I would also like to thank all the faculty members in the Forest Resource Management program for their insights, staff of the Division of Forestry and Natural Resources for all their support, to my friends in the room of 339 for their concern and for the fun environment and to all my friends here and back in Nepal for their friendship. 


\section{TABLE OF CONTENTS}

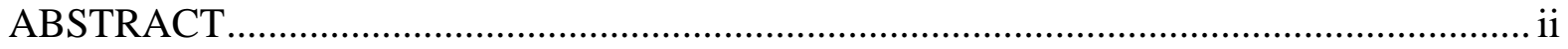

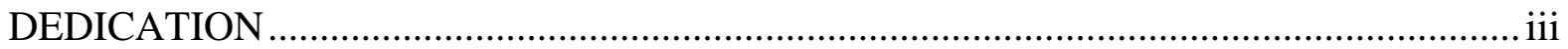

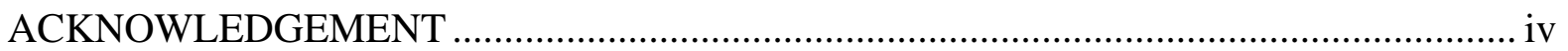

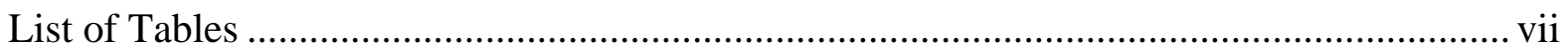

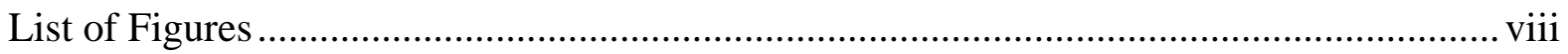

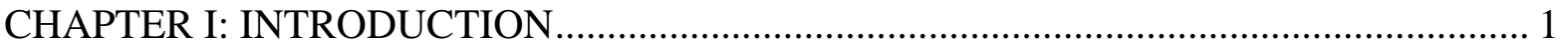

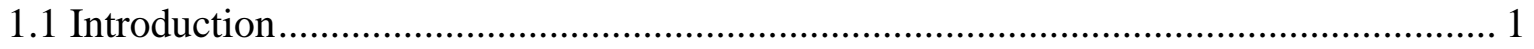

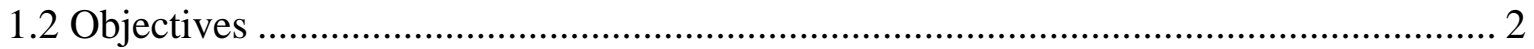

1.3 Organization of the Study ………………………….............................................. 3

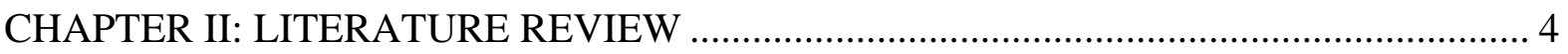

2.1 Non Industrial Private Forest Landowners in West Virginia.............................................. 4

2.2 NIPF Landowner Characteristics and Forest Management Behavior............................... 5

2.3 NIPF Landowner Objectives, Attitudes and Forest Management Behavior..................... 6

2.4 NIPF Landowners and Risk ............................................................................... 10

2.5 Harvesting Behavior ………………………………….......................................... 11

2.6 Forest Management Expenditures............................................................................ 13

2.7 NIPF Landowner Awareness of Forestry Educational and Assistance/Incentive

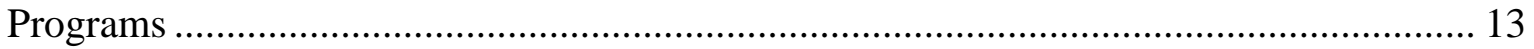

CHAPTER III: WEST VIRGINIA FOREST LANDOWNERS: A LOOK AT THEIR CHARACTERISTICS AND FOREST MANAGEMENT DECISION .................................. 15

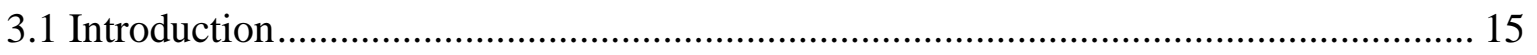

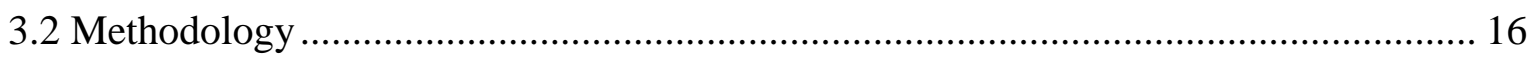

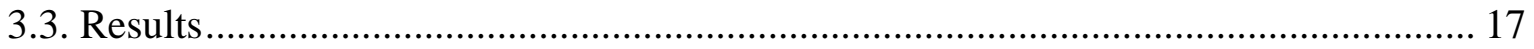

3.3.1 Survey Response ............................................................................................ 17

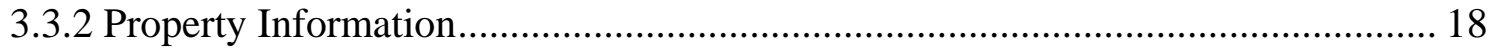

3.3.3 Landowner Objectives ...................................................................................... 23

3.3.4 Forest Management and Investment ………………............................................ 25

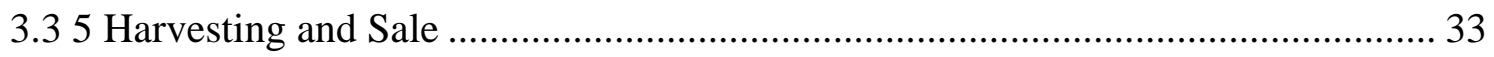

3.3 6 Use of Forestry Assistance/Incentive and Educational Programs .......................... 39

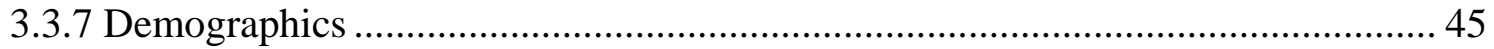

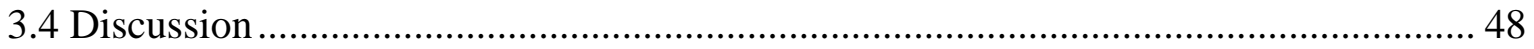




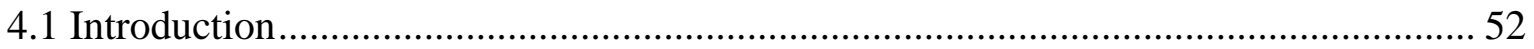

4.2 Theoretical Model ............................................................................................... 53

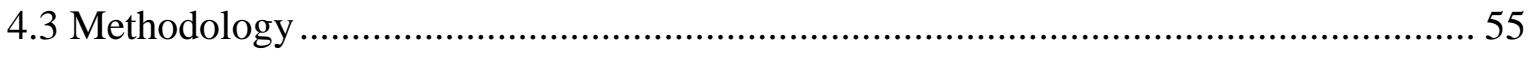

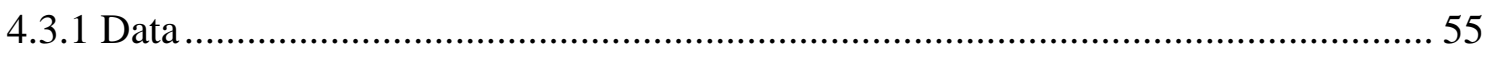

4.3.2 Empirical Model and Definition of the Variables............................................. 56

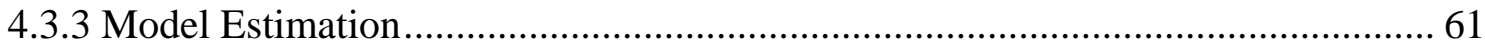

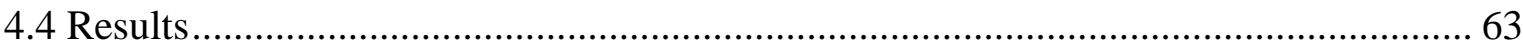

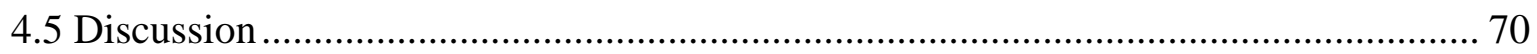

CHAPTER V: SUMMARY AND CONCLUSIONS ..................................................... 77

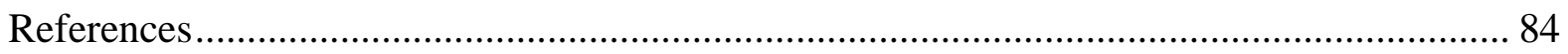

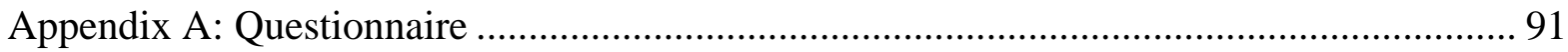

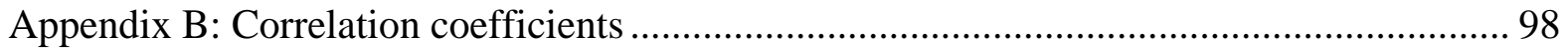

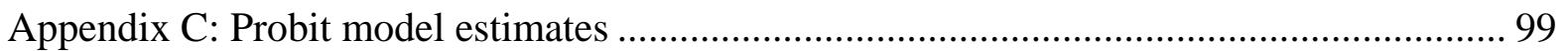

Curriculum Vitae ....................................................................................................... 100 


\section{List of Tables}

Table 3. 1: Summary of the forest land ownership size (in acres) by forest type of the NIPF survey respondents, West Virginia, 2005.

Table 3. 2: The relative importance of reasons for owning a forest land for NIPF survey respondents, West Virginia, 2005.

Table 3. 3: Acreage owned by the different managers of the NIPF forestlands, West Virginia, 2005. 26

Table 3. 4: Summary of the expenditures per acre in property taxes for the NIPF survey respondents' forestlands in 2004, West Virginia. 30

Table 3. 5. Appraised and estimated values of the forest land per acre owned by the NIPF survey respondents, West Virginia, 2005.

Table 3. 6. Appraised and estimated values of the timber per acre owned by the NIPF survey respondents, West Virginia, 2005.

Table 3. 7. Acreage harvested in the most recent timber harvest by the NIPF survey respondents, West Virginia, 2005.

Table 3. 8 Association between the forest management activities that the NIPF respondents conducted in 2004 and their awareness about the forestry incentive/assistance programs, West Virginia.

Table 4. 1: Description of the independent variables in the empirical models that examine the factors affecting landowners' decision to engage in forest management activities, West Virginia.

Table 4. 2: Descriptive statistics of the dependent and independent variables used in the models that examine the factors affecting landowners' decision to engage in forest management activities, West Virginia, 2000-2004.

Table 4. 3: Comparison of the four logit models examining the factors affecting NIPF landowners' decision to engage in four different categories of forest management activities, West Virginia ( $\mathrm{n}=244)$.

Table 4. 4: Parameter estimates of the logit model that examines the factors affecting NIPF landowners' decision to engage in timber harvesting activities, West Virginia $(n=240)$....... 65

Table 4. 5: Parameter estimates of the logit model that examines the factors affecting landowners' decision to engage in silvicultural activities, West Virginia $(\mathrm{n}=182)$. 66

Table 4. 6: Parameter estimates of the logit model that examines the factors affecting landowners' decision to engage in property management activities, West Virginia (n=182). 68 Table 4. 7: Parameter estimates of the Logit model that examines the factors affecting landowners' decision to engage in wildlife habitat management and recreational improvement activities, West Virginia $(\mathrm{n}=182)$. 


\section{List of Figures}

Figure 3. 1. Comparison by ownership size of the distribution of the survey respondents and the distribution of the West Virginia private forest landowners as reported by Birch and Kingsley (1978). 18

Figure 3. 2: Distribution of NIPF survey respondents by number of parcels of forestland owned, West Virginia, $2005(\mathrm{n}=239)$. 19

Figure 3. 3: Distribution of NIPF respondents by year of first parcel acquisition, West Virginia, $2005(n=226)$.

Figure 3. 4: Distribution of NIPF respondents by mode of forestland acquisitions, West Virginia, $2005(n=238)$.

Figure 3. 5: Source of forestland acquired by NIPF survey respondents, West Virginia, 2005 $(\mathrm{n}=238)$.

Figure 3. 6: Distribution of the NIPF survey respondents by the change in the total area of forest landholding, West Virginia, 2005 ( $n=240)$. 22

Figure 3. 7: Primary reason for the decrease in forest land acreage among NIPF survey respondents, West Virginia, $2005(\mathrm{n}=29)$.

Figure 3. 8: Individual or group to whom NIPF survey respondents have sold or given away their forestland, West Virginia, $2005(n=17)$.

Figure 3. 9. Distribution of NIPF survey respondents by distance of place of residence to the nearest forest property, West Virginia, $2005(n=238)$.

Figure 3. 10: Distribution of NIPF respondents by place of residence, West Virginia, 2005 $(n=240)$

Figure 3. 11: Primary reason for owning the forestland by percentage of owners and ownership size, West Virginia, $2005(\mathrm{n}=240)$.

Figure 3. 12: Manager of the forestland owned by NIPF survey respondents, West Virginia, $2005(n=238)$.

Figure 3. 13: Distribution of NIPF survey respondents by whether a written forest management had been prepared for their forest property, West Virginia, 2005 ( $n=240)$...... 27

Figure 3. 14: Distribution of NIPF survey respondents who have a written forest management plan by whether they have followed the prescribed treatments in the management plan, West Virginia, $2005(\mathrm{n}=28)$. 27

Figure 3. 15: Distribution of NIPF survey respondents by their interest in obtaining a written forest management plan for their forest property, West Virginia, $2005(\mathrm{n}=244) \ldots \ldots \ldots \ldots \ldots . . . . .28$

Figure 3. 16: Perceived effect of taxes on the management and use of the forest land by the NIPF survey respondents, West Virginia, 2005 ( $n=233)$.

Figure 3. 17: Distribution of NIPF survey respondents by tax programs affecting forest management decisions, West Virginia, 2005 (n=61)..... 
Figure 3. 18: Distribution of NIPF survey respondents by whether they have had their forest land appraised, West Virginia, 2005 ( $n=244)$. 30

Figure 3. 19: Distribution of NIPF survey respondents by whether they have had their timber appraised, West Virginia, $2005(\mathrm{n}=244)$... 31

Figure 3. 20: Problems typically encountered by NIPF survey respondents in their forest property, West Virginia, $2005(\mathrm{n}=221)$.

Figure 3. 21: Percentage of NIPF survey respondents carrying out different types of forest management activities prior to 2004 and in 2004, West Virginia $(n=181)$.

Figure 3. 22: Distribution of NIPF survey respondents by whether they have harvested or sold timber in between 2000 and 2005, West Virginia $(n=244) .$.

Figure 3. 23: Reasons for harvest or sale of timber by the NIPF survey respondents between 2000 and 2005, West Virginia $(n=239)$.

Figure 3. 24: Distribution of NIPF survey respondents by year of most recent harvest, West Virginia, $2005(n=25)$.

Figure 3. 25: Distribution of NIPF survey respondents by types of harvest method used in the

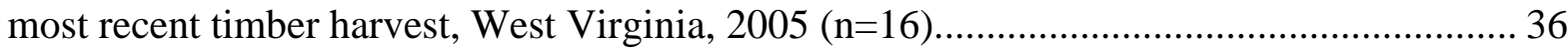

Figure 3. 26. Distribution of NIPF survey respondents by whether they have used the assistance/advice of a professional forester during the most recent timber sale, West Virginia $(n=53), 2005$. 37

Figure 3. 27: Distribution of NIPF survey respondents by the types of professional forester used during the most recent timber sale, West Virginia, $2005(\mathrm{n}=9)$.

Figure 3. 28: Reasons for not harvesting or selling timber by NIPF survey respondents, West Virginia, $2005(n=224)$. 38

Figure 3. 29: Future timber harvest and sale intentions of NIPF survey respondents, West Virginia, $2005(n=244)$. 38

Figure 3. 30: Distribution of the of NIPF survey respondents by how aware they are about existing forestry assistance/incentive programs, West Virginia, 2005 (n=104). 39

Figure 3. 31: Distribution of the of NIPF survey respondents who were aware of the existing forestry assistance/incentive programs by whether they had used it or not, West Virginia, $2005(n=44)$

Figure 3. 32: Use of existing forestry assistance/incentive programs by the NIPF survey respondents, West Virginia, $2005(\mathrm{n}=30)$......

Figure 3. 33: Satisfaction level of the NIPF survey respondents after using the Forestry Assistance/Incentive and Educational Programs designed for forest landowners, West Virginia, $2005(\mathrm{n}=30)$.

Figure 3. 34: Attendance of NIPF survey respondents to educational programs designed for forest landowners, West Virginia, $2005(n=214)$.

Figure 3. 35: Distribution of the different sponsors or co-sponsors of educational programs attended by the NIPF survey respondents, West Virginia, $2005(\mathrm{n}=8)$. 
Figure 3. 36: Preferred topics for educational programs by NIPF survey respondents, West Virginia, 2005 ( $\mathrm{n}=168)$.

Figure 3. 37: Preferred learning tools by NIPF survey respondents for effective delivery of

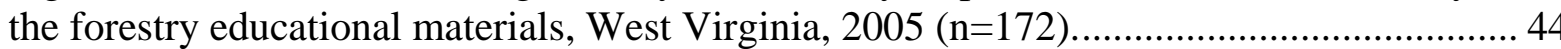

Figure 3. 38: Distribution of NIPF survey respondents by whether they have membership to forest-related organizations, West Virginia, $2005(\mathrm{n}=233)$. 45

Figure 3. 39: Distribution of NIPF survey respondents by age, West Virginia, 2005 ( $n=224)$.

Figure 3. 40: Distribution of NIPF survey respondents by gender, West Virginia, 2005 $(\mathrm{n}=229)$. 46

Figure 3. 41: Distribution of NIPF survey respondents by race, West Virginia, 2005 ( $n=220)$. 46

Figure 3. 42: Distribution of NIPF survey respondents by education level, West Virginia, $2005(\mathrm{n}=231)$

Figure 3. 43: Distribution of NIPF survey respondents by occupation, West Virginia, 2005 $(\mathrm{n}=242)$.

Figure 3. 44: Distribution of NIPF survey respondents by annual household income, West Virginia, 2005 ( $\mathrm{n}=187)$. 


\section{CHAPTER I: INTRODUCTION}

\subsection{Introduction}

The United States is a major world exporter of forest products, along with Canada and European Union. The value of the forest products exported in 2006 totaled $\$ 6.3$ billion (USDA FAS 2007). Forest resources are thus an integral part of the nation - vital to its social and economic well-being. The U.S. has a large timber resource base with nearly one-third (i.e., 747 million acres) of its land forested (Smith et al. 2000) and nearly two-third of the total forestland classified as timberland (USDA Forest Service 1990). The nation's timber inventory consists of almost $30 \%$ of the softwood growing stock and about $70 \%$ of the hardwood growing stock on the private lands (USDA Forest Service 1990). Furthermore, most of the growing stock inventory on private lands lied in the East with the hardwood growing stock almost equally divided in the north and south. These private lands are owned by nearly 10 million private individuals who own about 422 million acres of forest and other wooded land of the nation (National Atlas 2006). With harvests from the public forestlands decreasing due to current federal and state level regulations, the timber flow from private forestlands is increasingly of greater importance (Haynes 2002).

Eastern forests cover about 384 million acres and are largely in private ownership (83\%) and most of them are owned by nonindustrial private forest (NIPF) landowners (National Atlas 2006), so their forest management decisions might have an important impact on the nation's future timber supply. While the importance of private forestlands cannot be overemphasized, the supply behavior of the private forest owners has posed as one of the major uncertainties in projecting the future harvest levels and inventories (Adams et al. 2001). Unlike industrial landowners, NIPF landowners have been identified as landowners 
with a wide range of motivations not directed solely towards financial returns (Newman and Wear 1993, Conway et al. 2003).

Since NIPF landowners are so diverse, there is a need to better understand the determinants of their decisions so that policies could be in place to motivate the landowners in forest management and investment. NIPF landowners' forest management and investment decisions have been a topic of numerous studies (e.g., Greene \& Blatner 1986, Romm et al. 1987, Bliss \& Martin 1990, Nagubandi et al. 1996, Erickson et al. 2002, Elwood et al. 2003). Also there have been a number of voluntary forestland management programs instituted to motivate the NIPF landowners towards forest management (Clawson 1979). However, these programs have had limited success because of their emphasis on timber production. There is therefore the need for a deeper understanding of the other factors that motivate NIPF landowners. Further, even though NIPF landowners have been a topic of extensive studies in other regions, there exists little information about the NIPF owners in the Eastern U.S. and more so in West Virginia. This study is thus aimed at better understanding the State's NIPF landowners' characteristics and their forest management decisions.

\subsection{Objectives}

The main objective of this research is to conduct a comprehensive survey of NIPF landowners in West Virginia to provide information on the different aspects of their behavior related to the management, production and utilization of forest resources and implications on the hardwood resources of the State. The specific objectives of this study are:

1. To characterize NIPF landowners in West Virginia, and

2. To examine the factors affecting NIPF landowners' decision to engage in forest management activities. 


\subsection{Organization of the Study}

This study is divided into five chapters and presents two analyses on understanding the State's NIPF landowners' characteristics and their forest management decisions. Chapter II provides an overall literature review pertinent to the study. Chapter III covers the first analysis on West Virginia Forest Landowners: A Look at Their Characteristics and Forest Management Decision. Chapter IV covers the second analysis on Forest Management Decisions of Non-Industrial Private Forest Landowners of West Virginia. Chapter V provides the overall summary and conclusions for the two analyses. 


\section{CHAPTER II: LITERATURE REVIEW}

\subsection{Non Industrial Private Forest Landowners in West Virginia}

Forestland ownership of United States can be broadly classified into two categories: public and private. Private ownership of forestland is further classified into industrial and non-industrial. Industrial forest landowners own and operate commercial wood-using plant while NIPF landowners do not (Smith 1999).

West Virginia is the third most forested state and the second leading hardwood state in the nation with 22.3 billion cubic feet of hardwood growing stock. Forests cover 12.0 million acres of the state's 15.4 million acres of land. Almost all of the forested land i.e., 11.8 million acres (98.3\%) is classified as commercial forestland*, which is available for timber production (Griffith and Widmann 2003). Furthermore, in terms of forestland ownership, $83 \%$ of the forestland and $80 \%$ of the wood volume in the State is under private ownership (White 1993). Approximately, 260,000 NIPF landowners own 9.7 million acres of forestland in the State (USDA Forest Service 2007).

Birch and Kingsley (1978) had characterized the private forest landowners of West Virginia. They had found that majority of the landowners owned a single parcel of forestland and the average ownership size was 49.8 acres. $30 \%$ of the landowners owned the forestland for fewer than 0 years and 13\% had owned the forestland for more than 25 years. Majority of the landowners lived near or on their forest property (61\%). Primary reasons for owning the land had been for residence, expectation of increase in the land value, recreation and land investment. Results also showed that $65 \%$ of the landowners were older than 45 years and

\footnotetext{
* Commercial forestland is any forested area capable of producing 20 cubic feet of timber per acre per year, which has not been withdrawn from timber harvest by law or statute (Hubbard et al. 1998)
} 
$23 \%$ older than 65 years. Education level was low with $43 \%$ of the landowners who did not have more than 8 years of formal education and only 18\% were educated beyond high school. Also, half of the landowners were either retired or employed as unskilled labor. Only $13 \%$ of the landowners were professionals, executives, or white collars. The income level was also low with $56 \%$ of the landowners with a gross income of less than $\$ 10,000$.

Since NIPF landowners own a significant proportion of forest land and associated forest resources, they play a vital role in the determining the future trend of timber supply in the nation and therefore are the focus of many studies.

\subsection{NIPF Landowner Characteristics and Forest Management Behavior}

NIPF landowner characteristics have been the interest of study for many researchers due to their diversity and their possible links in interpreting the forest management behavior of the NIPF landowners. NIPF forest management decisions have been found to be associated with their landowner characteristics.

Straka et al. (1984) showed positive relationships among size of forest holding, landowners' financial position and management intensity in Mississippi. Greene and Blatner (1986) used discriminant analysis to come up with a model to differentiate between timber managers and non managers based on the characteristics of the woodland owners in Arkansas. Discriminant analysis is a multivariate procedure that identifies and weighs characteristics associated with known behavioral groups, and can provide an integrated model to classify individuals and predict behavior. Contact with a forester, landowner being a farmer, and landowner being well-educated were the characteristics that were found to be positively associated with timber management. Large woodland size was also shown to favor timber management. 
Romm et al. (1987) explored the relationship between the investment behavior of the NIPF landowners and owner and ownership characteristics in northern California. A logit regression was used to analyze the survey data to assess the influence of owner and ownership characteristics on the incidence of forestry investment. Their results showed that full-time residents and landowners with high income $(>\$ 50,000)$ were more likely to invest in forestry. In contrast, absentee landowners, middle income group landowners (annual income of $\$ 20,000-\$ 50,000$, and older landowners (older than 64 years) were less likely to invest in forestry. Unlike results from previous studies, ownership size was not found to be a significant predictor of the probability of investment in forestry. The ownership size was however the strongest predictor of the probabilities of investment associated with timber harvest. Dennis (1989) looked at the determinants of timber supply from the private forests using Tobit model. The results of his study suggested that high per acre volumes and presence of commercially valuable species were important determinants of harvest behavior. The results also showed that the quantity of timber harvested was inversely related with exogenous income and years of formal education, and positively associated with interest rates.

\subsection{NIPF Landowner Objectives, Attitudes and Forest Management Behavior}

Similar to NIPF owner and ownership characteristics, the objectives of the NIPF owners for forest land ownership has been found to be linked with forest management and investment decisions. Greene and Blatner (1986) found the primary objectives for ownership were associated with timber management. Their study showed that landowners with recreation, wildlife, and grazing as primary objectives had higher probabilities of undertaking timber management. Bliss and Martin (1989) used qualitative methods to identify factors that 
motivated landowners to engage in forest management activities. The results showed that external incentives such as income, production opportunities, technical assistance, and forest tax and other incentive programs influenced the timing and extent of the management activities. Kuuluvainen et al. (1996) investigated the link between landowner objectives and their timber supply in southern Finland using Tobit model (cross-sectional censored regression model). Multi-objective owners’ were found to be more active in harvesting activities than the single objective landowners. The study suggested that attitudes and ownership objectives played a quantifiable role in the variation of timber harvest rates, and that these attitudes and ownership objectives could be used to forecast major trends in future timber supply.

Lonnstedt (1997) carried out a qualitative study on NIPF landowners' decision process. The goals of the landowners were grouped into five classes: formal and informal economic goals, production and environmental goals, and intangible goals. The results indicated that the NIPF landowners' goals were not directed toward maximizing the return on capital however they were concerned about cash flow which had to be at least positive or even above a specified level. The study also indicated that the weights allocated to different goals were dependent upon the phase of the term of ownership. During the setup phase when there are large financial needs, production goals took a priority resulting in large final cuttings. In the stewardship phase, landowners were found to be interested in long-tern management with cuttings falling below the long-term sustainable yield. In the change of generation phase, financial considerations are no longer a priority and preparations are made for the next generation to take over. Thus, the study suggested that NIPF landowners have a long-term perspective on forestry extending beyond a single generation and that their 
decisions will not always coincide with the forest policy or market changes but rather will be dependent on the time perspective and change in the income needs of the individuals.

Karppinen (1998) also examined NIPF landowners in Finland by analyzing their cutting and silvicultural behavior based on forest values and objectives using logit models. The author classified landowners as multi-objective, recreationists, self-employed and investors. Non-farmers, part-time residents, and landowners with small holdings were more likely to be recreationists. The probability of belonging to the group of investors increased with the age and larger forest holding. The self-employed owners were young, full-time residents and with no higher education. The study also showed that multi-objective owners harvested more for sale and household use than other forest owners. Multi-objective owners and self-employed owners sold timber more frequently than the other two groups. Multiobjective owners were also found to be most active in carrying out the silvicultural operations. The author suggested that emphasis on economic benefits alone did not lead to the most active silvicultural and harvesting behavior. NIPF owner's decisions were found to be affected by a wide range of external events and changing internal needs and objectives however general forest values. Long-term objectives however were not found to be strongly correlated.

Erickson et al (2002) looked at NIPF landowners' motivation for retaining and protecting woodlots in two townships of Michigan using dimensional analysis. Aesthetic appreciation was the strongest reason for owning the woodlots followed by environmental protection. Retaining the woodlots for economic reasons received lower priority. The management of woodlots was mostly hands-off as active management was not frequent. Parttime farmers and non-farmers were inclined to manage their woodlots for recreational 
purposes while farmers were more likely to be involved in selective logging. Elwood et al. (2003) found that good stewardship, place for residence, and bequest motives were among the most important objectives for owning the forestland for the NIPF landowners in Oregon. However owners with larger forestlands were more likely to have management plans and focus on timber production, grazing, and generating income.

Finley and Kittredge (2006) looked at the private forest landowners in Massachusetts to explore the association between their values and active forest management. The study divided the landowners into three unique segments on the basis of their values towards their forestlands. The first segment of landowners highly valued privacy and contemplative values of forest (e.g., scenery, recreation). The second segment of landowners valued nature, environmental quality and protection, and they believed in leaving the forestland unmanaged. The third and final segment of landowners was indifferent of either the environmental protection or privacy and other contemplative values. Their results suggested that majority (67\%) of landowners valued privacy and other contemplative values (scenery, personal recreation, and a pleasing residential setting) but were not opposed to utilizing forests for wood products. This segment had the highest percentage (39\%) of landowners enrolled in forest stewardship. There was a second segment of landowners (23\%) who valued nature, environmental quality, and protection and believed on letting nature taking its course, a smaller proportion (28\%) of these landowners were interested in forest stewardship. The final segment of landowners (10\%) owned larger tracts of forestlands and were usually absentee owners. They were with indifferent to environmental protection, privacy, and other contemplative values and were more likely to have plans sell or develop their forestlands. This segment was thus least likely (27\%) to be interested in forest stewardship. 
While researchers have found that most NIPF landowners value nontimber amenities more than financial returns from the forestland, Newman and Wear (1993) hypothesized that NIPF owners managed their land in a manner consistent with the profit motives but that their production decisions involved additional considerations beyond timber. The production function of the NIPF landowners' was however different than that of the industry's profit function explained in part by the high shadow values of growing stock. The study suggested that the complex relationship between standing forests and nontimber amenities would account for the other part of the variation in the production function of the NIPF landowners.

\subsection{NIPF Landowners and Risk}

Since forest management decisions include uncertainty, decisions of the NIPF landowners also depend on their risk perception towards forests investments. In this line, Lonnstedt and Svensson (2000a) looked at the risk preferences of NIPF landowners and how risk affected their investment decisions. The results of the study suggested that landowners perceived direct economic risk factors (decreasing timber price, increasing costs in forestry, financial problems due to interest rates) as a greater problem than the indirect economic risks (rotting, wind throw, insect damage). The landowners perceived investments in forestry as less risky than bank savings and stock investments. The study also reported an association between forest owner's economic situation and his or her attitude towards risk. That is, forest owners who were more dependent on the income through forestry were more concerned of the economic factors. However forest owners concerned directly with farming and forestry were more likely to make riskier investments perhaps because these forest owners were prepared to take risks in the areas that they know best. Lonnstedt and Svensson (2000b) also made comparisons between NIPF landowners' returns and risks on timberland and other 
investment alternatives (grain and milk production, shares, and bank deposits). The results showed that the return from forest investment was relatively good but with high risk. Forest investment also showed negative correlations with grain production, shares, and bank deposits suggesting that landowners would be better off by reducing investments in timberland. However, the portfolio mixture was thought to depend on the individual landowners/ risk preferences.

Further Uusivuori (2002) presents a theoretical model dealing with the risk attitudes and the harvesting behavior of forest landowners. The results showed that risk attitudes were not constant and so the risk aversion of the landowners declined with increase in wealth. Also, when landowners are faced with a choice between a risky and a nonrisky investment, most landowners would want to split their investment between these two investments depicting that landowners apply nonconstant risk premium to their investments. This very same pattern was depicted in their harvesting behavior as landowners chose to harvest only a part of the forest for an expected financial return while leaving the other part uncut.

\subsection{Harvesting Behavior}

Since NIPF landowners own a large share of the US forests, their harvesting behavior affects the flow of timber into the market. The dependence on the timber flow from NIPF forest lands will increase even more due to the continuing reduction of timber harvesting in public lands and increasing demand for wood products (Haynes 2002).

Bliss and Grassl (1987) found that tract size and farm status were significantly related to the occurrence of timber harvest. Romm et al. (1987) also found that ownership size was the strongest predictor of the probabilities of investment associated with timber harvest. Henry and Bliss (1994) explored NIPF landowner's knowledge and its association with on 
timber harvesting, regeneration, and best management practices in west-central Alabama. NIPF owners who were satisfied with the post-harvest conditions in their forests were inclined to regenerate harvested stands and plan future harvests. Landowners with the knowledge of forestry and forest management practices were also more likely to plan for future harvests.

Cleaves and Benett (1995) looked at the timber harvesting of NIPF landowners in western Oregon. Harvest participation rates were positively associated with tract size, tenure, corporate organization, farm ownership, and income.

Conway et al. (2003) looked at how bequest motives, debt and non-market activities, and harvest decisions were interrelated and dependent on landowner preferences, market, and land characteristics in the Southeastern U.S. They suggested that with increasing parcelization, harvest activity would decline and forest parcels would be left for bequests. Also, with increasing urbanization, the number of absentee landowners increased and harvesting and non-timber uses of the land decreased. Moreover, their findings showed that landowners with high debt were more likely to harvest timber and less likely to leave it as bequest. Further, hunting behavior of the landowners was shown to be related with harvesting as well as with bequest motives. Landowners with non-timber preferences other than hunting were less likely to harvest and more likely to leave their forest property as bequests. In another study, Jin and Sader (2006) found that NIPF landowners held more stable ownership and carried out equal or more intermediate harvests compared to timber investment management organizations (TIMOs) and other short-term investors in northern Maine. 


\subsection{Forest Management Expenditures}

Forest management expenditures give a clear indication of how the forest landowners are managing their forest lands. However little information exists regarding the investment of the NIPF landowners in forest management activities. DeSteiguer (1984) indicated that changes in the level of investment were positively influenced by personal income and negatively influenced by interest rates. Zhang and Pearse (1996) reported a mean value of \$750.58 per hectare (in 1992 Canadian dollars) for the investment in cut blocks in British Columbia. Zhang and Flick (2001) had reported the mean value of reforestation investment for the cut sites to be \$111.92 per acre (in 1997 dollar values). Arano et al. (2002) studied the forest management expenses of Mississippi’s non-industrial private forest landowners. Property tax was the largest annual expenditure for all the surveyed landowners while site preparation, timber cruising, timber marking, and survey fees were greater than the expenses on property tax when only landowners who engaged in timber management activities were considered.

\subsection{NIPF Landowner Awareness of Forestry Educational and Assistance/Incentive}

\section{Programs}

There are a number forestry assistantship/incentive and educational programs that are being carried out by the Federal and State governments focusing on NIPF landowners. There are many government and private programs directed towards influencing the decisions of the NIPF landowners. The educational and assistance/incentive programs include a wide array of programs from workshops, seminars, to technical assistance to cost-share programs. These programs have been primarily focused towards timber production. However recently understanding the diverse goals of the NIPF landowners assistance/incentive programs are 
being implemented in a way that also captures the management aspects of the nontimber amenities that the NIPF landowners value.

In spite of this, many landowners do not take advantage of such governments programs. Birch and Kingsley (1978) reported that 23,000 owners or $11 \%$ of the landowners had received some kind of assistance while $49 \%$ of the respondents had reported that they were unaware of which agency to contact for assistance . Egan et al. (2001) studied the effectiveness of the Forest Stewardship Program in West Virginia and found that people who had the forest stewardship plan implemented the prescribed activities more so than those who were not given prescriptions for the particular type of activity. The study also showed that the participants of the forest stewardship program were less inclined to harvest timber for income. Henly et al. (1990) found that private forest management assistance program in Minnesota did little to improve the net economic efficiency of harvesting. They suggested the need for a shift in the role of the program from on-site technical assistance to a more advisory role. Bell et al. (1994) showed that attitudes and knowledge of forestry program would be more influential than the monetary incentives suggesting that indirect incentives would be more effective for landowner participation. Jennings and McGill (2005) looked at the effectiveness of the forest stewardship program in West Virginia and compared them with the results of Egan et al. (2001). The study indicated an increase in the rate of practice implementation of the programs. The study also found an increase in the satisfaction level of the landowners with the program components. Further, McGill et al., (2006) studied the landowners enrolled in West Virginia Forest Stewardship and investigated their satisfaction level following timber harvests. The results indicated monetary returns to be the most influential factor related to the satisfaction level. 


\section{CHAPTER III: WEST VIRGINIA FOREST LANDOWNERS: A LOOK AT THEIR CHARACTERISTICS AND FOREST MANAGEMENT DECISION}

\subsection{Introduction}

West Virginia is the second leading hardwood state in the nation making it an important hardwood resource base. The contribution of wood-related industry to the state's economy cannot be overemphasized. For example, while employment in most of the other industries like mining, primary metals, stone-clay-and glass, and chemicals fell during the 1980 and 2004 period, employment rose from 6.5 thousand to 11.8 thousand for wood products and furniture industries in that same period (Childs 2005). Eastern hardwoods will play an even more important role as southern forests continue to have less intensive forms of management and low rates of growth of hardwood timber (Haynes 2002).

In terms of forestland ownership, $76 \%$ of the state's forestland is owned by nonindustrial private forest (NIPF) landowners (Birch 1996). Due to this significant proportion of ownership, actions of this landowner group will have a significant impact on the availability of hardwood to the state and to the nation as a whole. Even though NIPF landowners have been a topic of extensive studies in other regions, there is very little information about the NIPF owners in the Eastern U.S., and more so in West Virginia. There have been studies on characterizing landowners' participation in Forest Stewardship Program and evaluating the effectiveness of this program in the state (e.g., Egan et al. 2001, Magill 2003, Magill et al. 2004, Jennings and McGill 2005). A detailed study on the characteristics and the management decisions of NIPF landowners in West Virginia has not been conducted since 1978 (Birch and Kingsley 1978). A comprehensive survey of NIPF landowners was thus needed to have a better understanding of the State's NIPF landowners' characteristics 
and their forest management decisions. This study presents the findings of a statewide survey carried out in the fall of 2005 . The study was conducted to characterize the state's NIPF landowners and their forestlands and to provide an insight into their forest management decisions.

\subsection{Methodology}

The study population was made up of landowners of West Virginia who indicated that they currently own a forest property. Since the intent of the study was to characterize all NIPF landowners of the state regardless of ownership size, the study population included all landowners irrespective of the size of their landholdings. Names and addresses of landowners were obtained from the State Tax Assessor’s Office. The State Tax Assessor’s Office provided the list of landowners who had paid the property taxes for their land. Dillman's (2000) Tailored Design Method was used to design the survey. The data for the study was collected from a mail survey conducted in the fall of 2005 to 2,100 randomly selected landowners. A total of three mailings: initial mailing with the questionnaire and two follow up mailings (first one with a follow up letter and the last one with a follow up letter and a questionnaire) were sent in order to increase the number of responses.

The survey instrument was developed with the aim of collecting comprehensive statewide information on NIPF landowners' characteristics and behavior towards forest management. The survey was divided into six sections: 1 ) property information (i.e., ownership size, forest composition, time of parcel acquisition, mode of parcel acquisition, and residence information); 2) landowner objectives; 3) forest management and investment (i.e., who manages the forestland, preparation of forest management plan, effect of tax on their management decisions, estimates of their forestland and timber value, perceived risks in 
timber management, problems typically encountered by owners in their forestland property, and forest management activities); 4) harvesting and sale (i.e., timber harvest information, reasons for harvesting, use of assistance from professional foresters during the harvest, reasons for not harvesting, and plans for future harvest); 5) use of forestry assistance/incentive and educational programs; and 6) demographics (i.e., membership to forestry-related organization, age, gender, ethnic background, education, profession, and annual household income).

Data from completed questionnaires were entered and compiled in Microsoft Excel. Summary statistics were computed for the variables collected in the survey using Statistical Analysis System (SAS).

\subsection{Results}

\subsubsection{Survey Response}

Out of the 2,100 questionnaires that were mailed out, 216 were returned due to undeliverable addresses and deceased landowners reducing the sample size to 1,884. A total of 855 mail surveys were received. However, 611 questionnaires were returned blank stating that they did not own any timberland property in West Virginia or had already sold their timberland property prior to the survey. The number of usable responses for the study was thus 244, with a $20 \%$ response rate. The distribution by ownership size of the NIPF respondents was then compared with that of the private landowners of West Virginia as reported by Birch and Kingsley (1978) (Figure 3.1). The Kolmogorov-Smirnov test (K-S test) indicated that the distribution of the NIPF respondents differed from that of the state population of private forest landowners (K-S test statistic=.37, p-value $<0.001$ ). Since the study by Birch and Kingsley (1978), the number of NIPF landowners has increased from 
207,500 to 260,000 , so the distribution pattern of the landowners might have changed. Also, the study by Birch and Kingsley had extrapolated the results of 710 questionnaires to the state level population and so the sampling population might have brought about this disparity in the distribution.

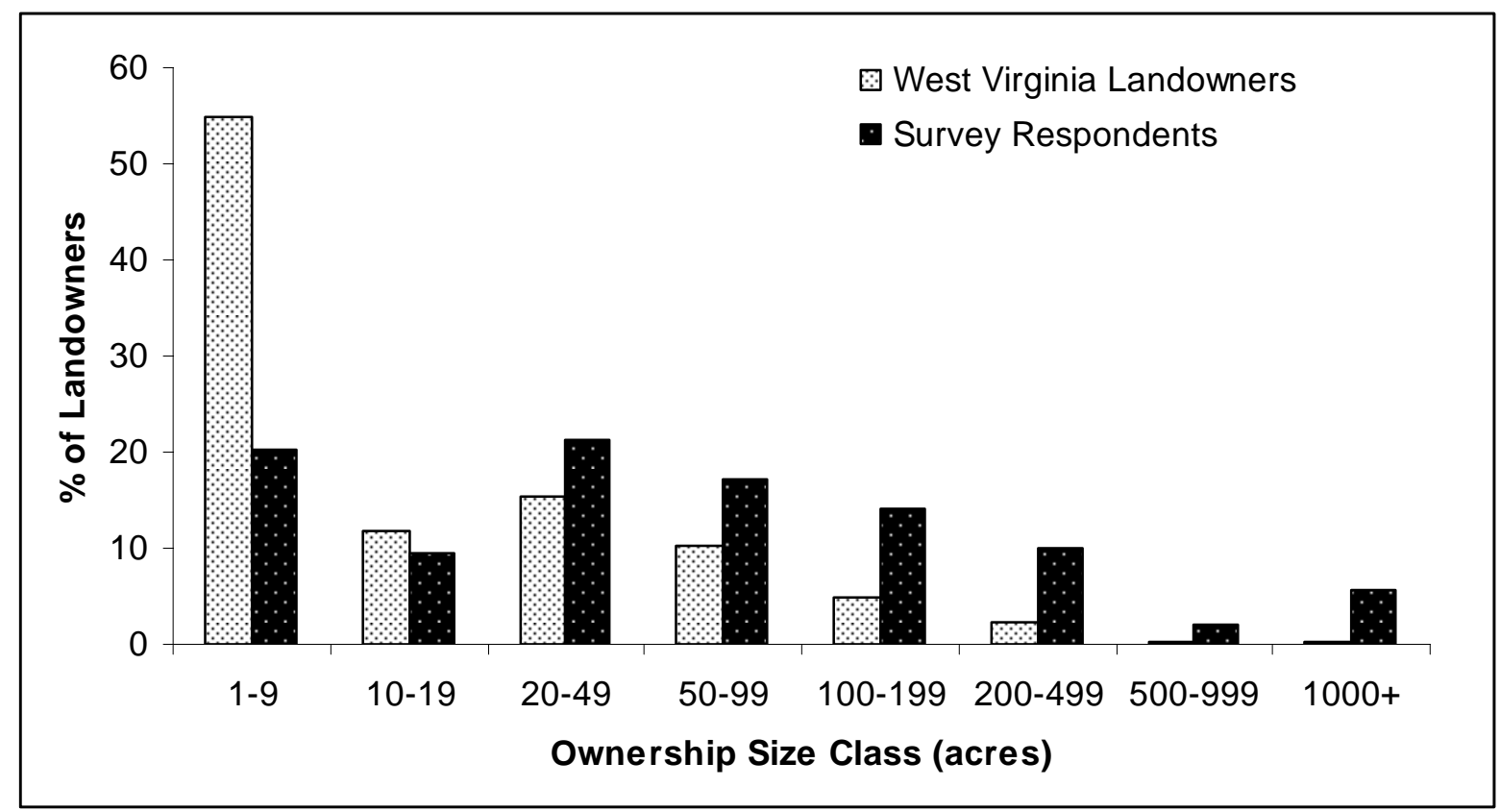

Figure 3. 1. Comparison by ownership size of the distribution of the survey respondents and the distribution of the West Virginia private forest landowners as reported by Birch and Kingsley (1978).

\subsubsection{Property Information}

The majority of respondents (55\%) owned a single parcel of forestland (Figure 3.2) however a few (5\%) owned over 10 parcels. The median forest ownership size was 43 acres (Table 3.1). The hardwood forest was the dominant forest type (82\%) with an average of 3,455 acres with pine as the second largest forest type (6\%) (Table 3.1). 


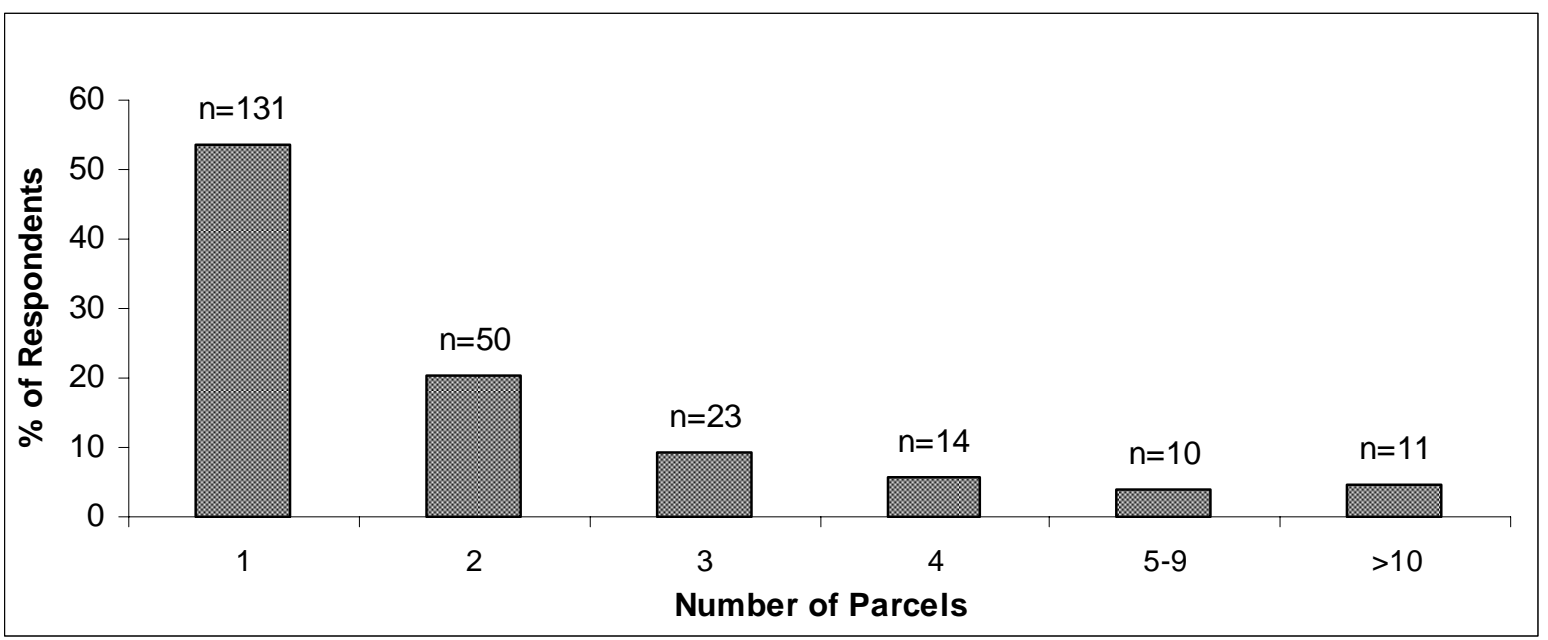

Figure 3. 2: Distribution of NIPF survey respondents by number of parcels of forestland owned, West Virginia, 2005 ( $\mathrm{n}=239)$.

Table 3. 1: Summary of the forest land ownership size (in acres) by forest type of the NIPF survey respondents, West Virginia, 2005.

\begin{tabular}{lrrrrrrr}
\hline \multicolumn{1}{c}{ Forest Type } & \multicolumn{1}{c}{ \% } & \multicolumn{1}{c}{ Mean } & Std Dev & \multicolumn{1}{c}{ Min } & \multicolumn{1}{c}{ Max } & Median & \multicolumn{1}{c}{ Range } \\
\hline Hardwood Forest & 81.46 & 4736 & 33658 & 1 & 341250 & 40 & 314249.00 \\
Pine Forest & 6.37 & 997 & 5339.1 & 0.25 & 30000 & 7 & 29999.75 \\
Mixed Forest & 5.74 & 498 & 4720.6 & 20 & 50000 & 20 & 49980.00 \\
Others & 5.77 & 1437.1 & 50500 & 0.46 & 50500 & 10 & 50499.54 \\
Total Forest* & 100.00 & 4114 & 35175 & 0.5 & 375000 & 43 & 375000.00 \\
\hline
\end{tabular}

* The individual forest type results do not sum up to the total forest results since the reported total forest acres were not always broken down to different forest types accurately.

Majority (58\%) of the respondents acquired their first property between 1976 and 2000 (Figure 3.3) and more than 12\% of the respondents had acquired their first forest property after 2000. Most of the forest properties were acquired through purchase (71\%) (Figure 3.4). Inheritance (24\%) was the second most common mode of acquisition. 


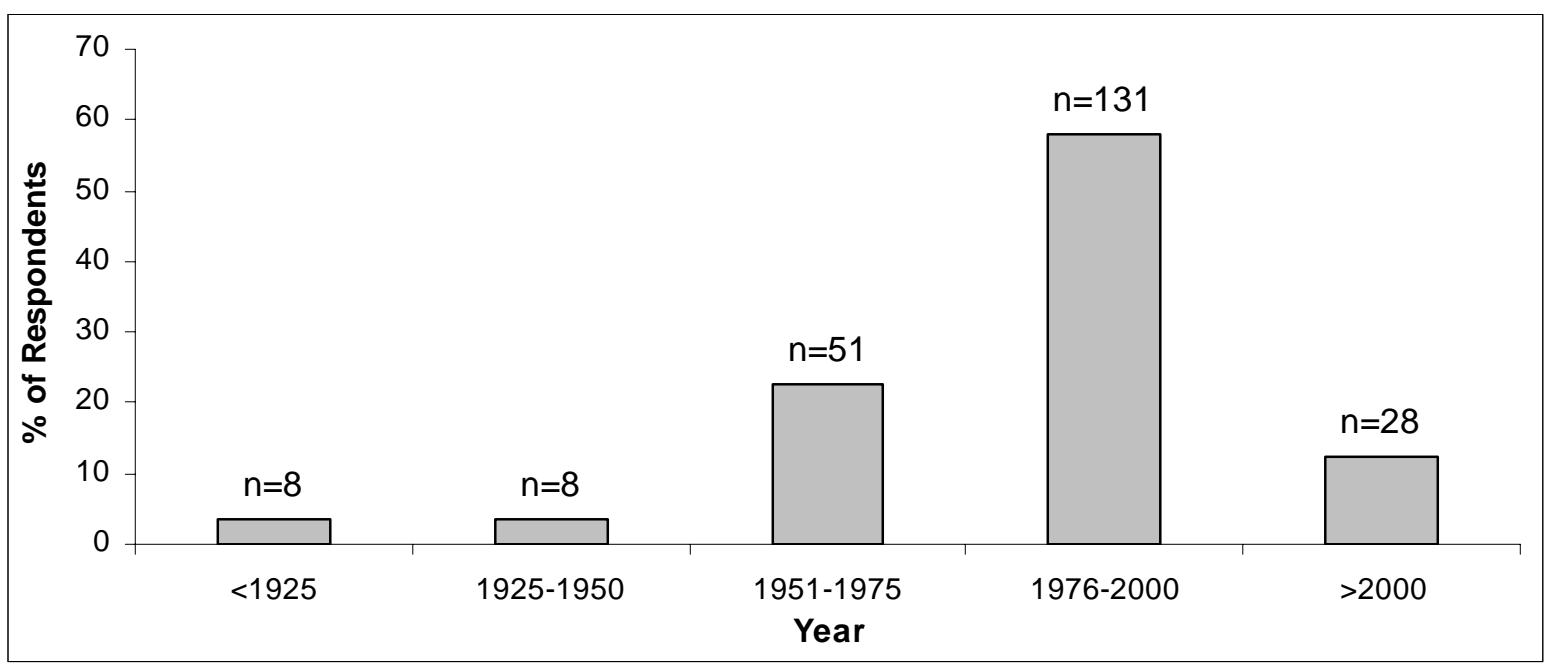

Figure 3. 3: Distribution of NIPF respondents by year of first parcel acquisition, West Virginia, $2005(n=226)$.

The majority (52\%) of the respondents had acquired their property from family members while $38 \%$ of the respondents had acquired their property through other individuals (Figure 3.5). While the majority (76\%) of the landowners had retained the size of the forest property that they initially acquired, $24 \%$ have reported changes in the size of their initial ownership (Figure 3.6). Of the landowners reporting change, $12.66 \%$ of them reported decrease in the size of the forestland while $10.97 \%$ reported an increase in the size of forestland acquisition. Of the landowners who had reported a decrease in the size of their forestland, the majority (56\%) of landowners sold a part of their property, $24 \%$ had built house and $10 \%$ of the landowners had bequeathed their forest property while others (10\%) had converted the forestland to other forms of land uses (e.g., pasture) (Figure 3.7). The pattern of acquisition of the property resembles the pattern of property transfer since $45 \%$ of the transfer has been made to another family member (Figure 3.8).

Majority (61\%) of the NIPF landowners resided within 5 miles of their forest property while more than 15\% resided more than 100 miles from their nearest property (Figure 3.9). Also, majority (82\%) of the NIPF landowners reside in West Virginia while the 
out of state landowners were mostly from the nearby states (namely: Kentucky, Maryland, Pennsylvania, Virginia, Delaware, New Jersey and North Carolina ) except a few who were from as far as Florida, Minnesota and California (Figure 3.10).

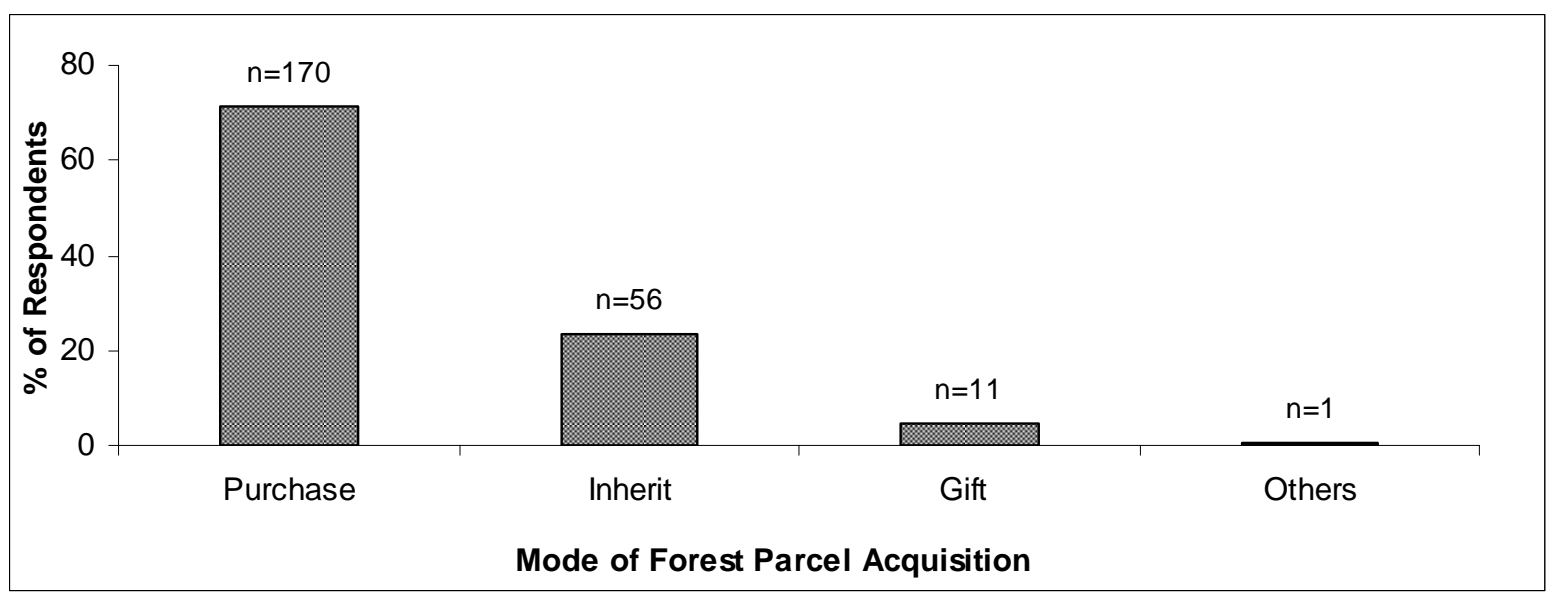

Figure 3. 4: Distribution of NIPF respondents by mode of forestland acquisitions, West Virginia, $2005(n=238)$.

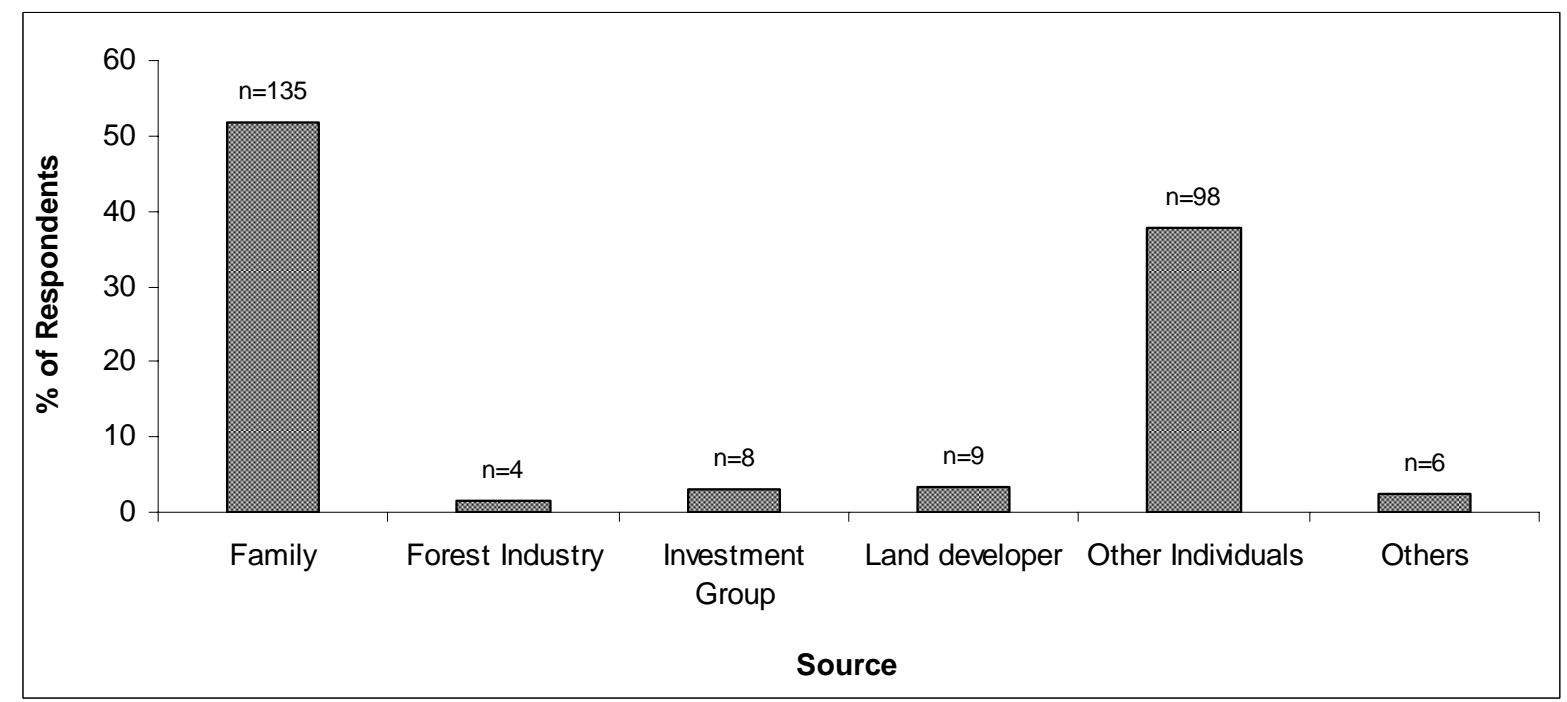

Note: Sum of the responses exceed the no. of responses since respondents chose more than one option.

Figure 3. 5: Source of forestland acquired by NIPF survey respondents, West Virginia, 2005 $(n=238)$. 


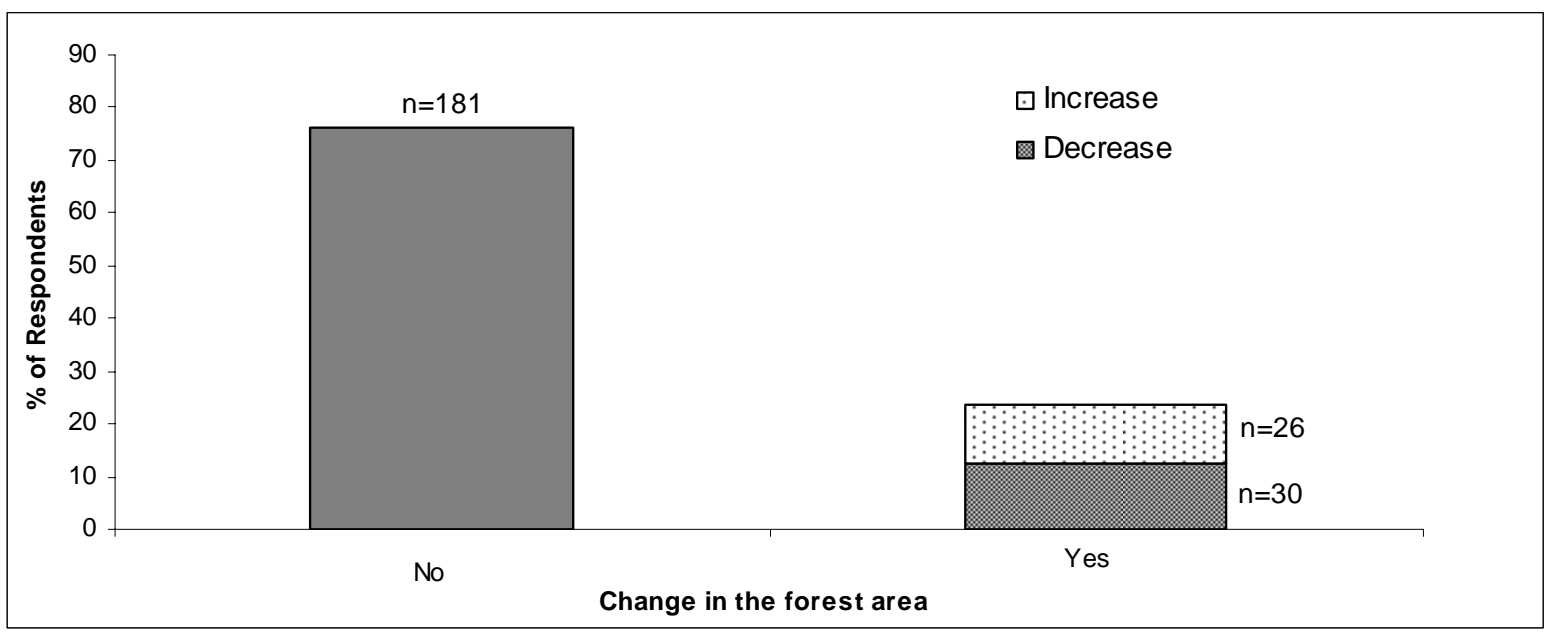

Figure 3. 6: Distribution of the NIPF survey respondents by the change in the total area of forest landholding, West Virginia, 2005 (n=240).

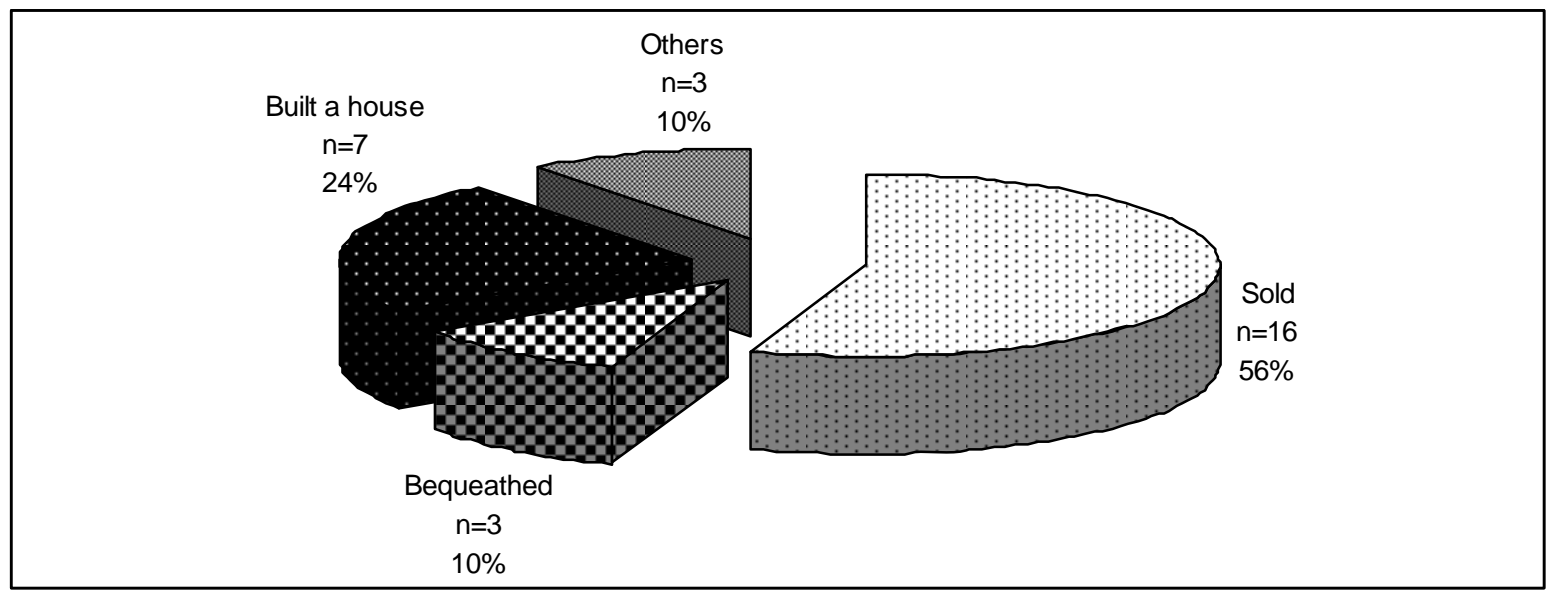

Figure 3. 7: Primary reason for the decrease in forest land acreage among NIPF survey respondents, West Virginia, $2005(n=29)$.

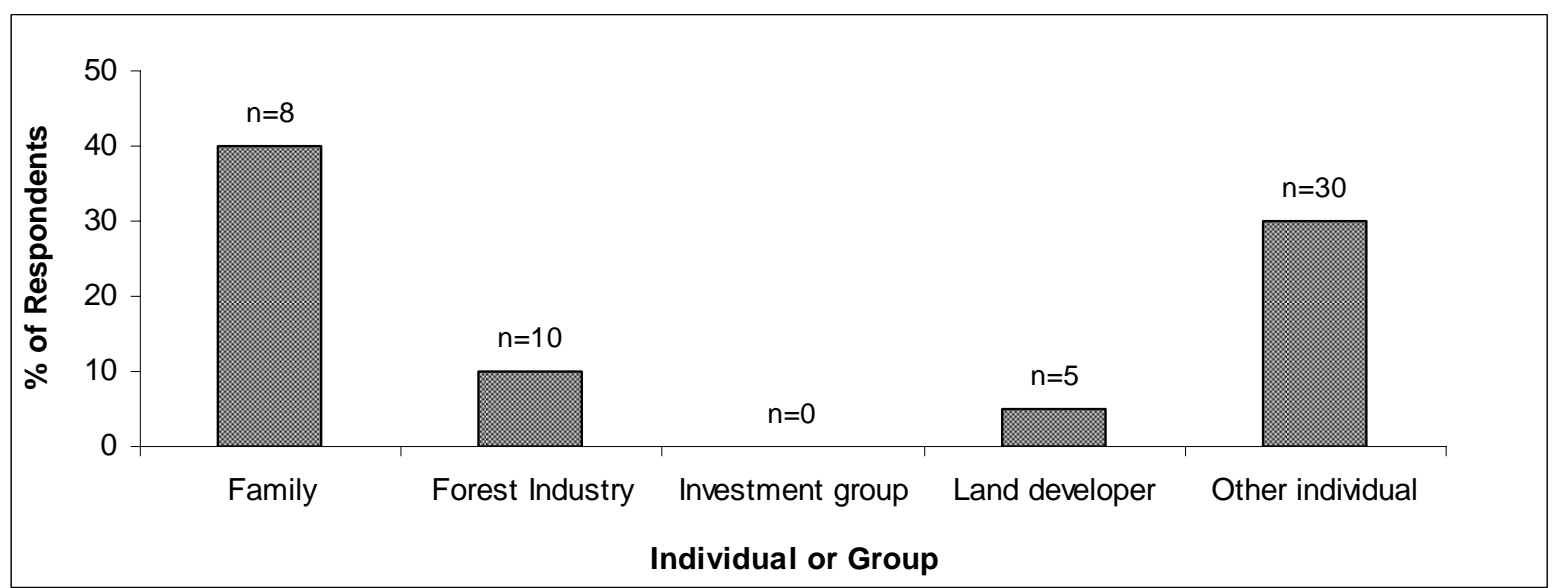

Figure 3. 8: Individual or group to whom NIPF survey respondents have sold or given away their forestland, West Virginia, 2005 ( $n=17)$. 


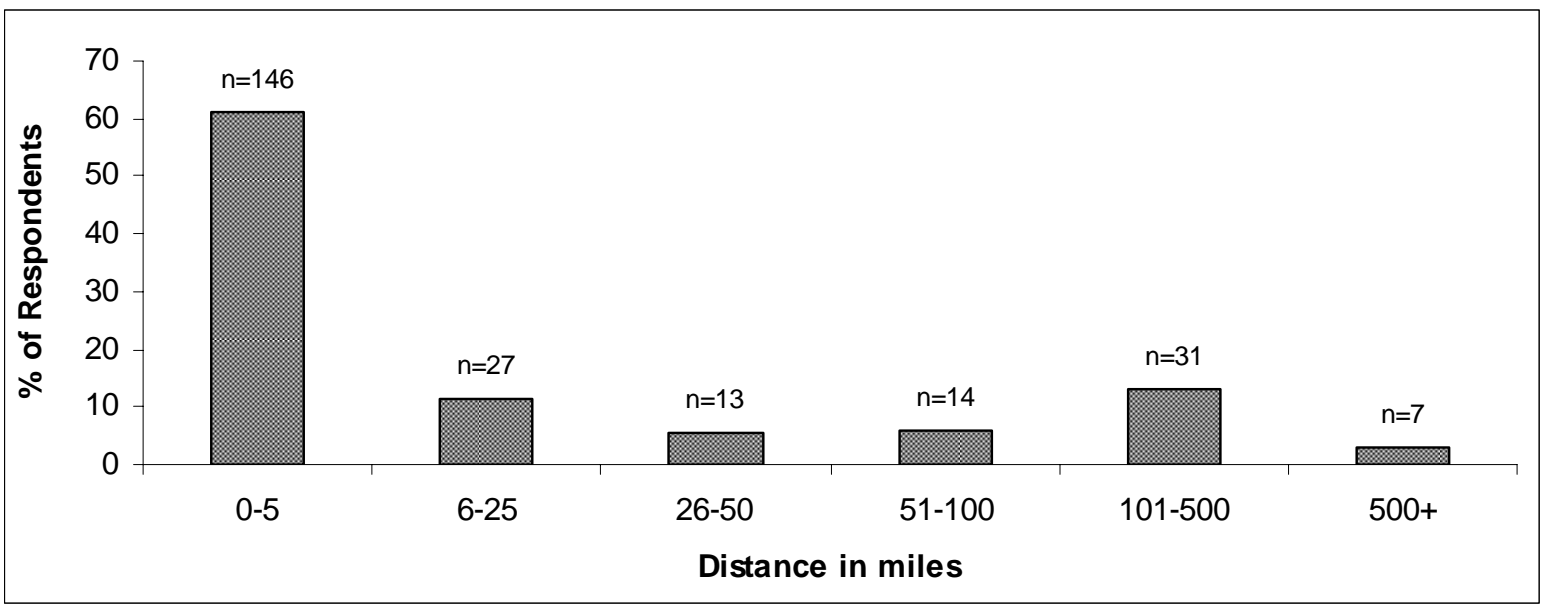

Figure 3. 9. Distribution of NIPF survey respondents by distance of place of residence to the nearest forest property, West Virginia, $2005(n=238)$.

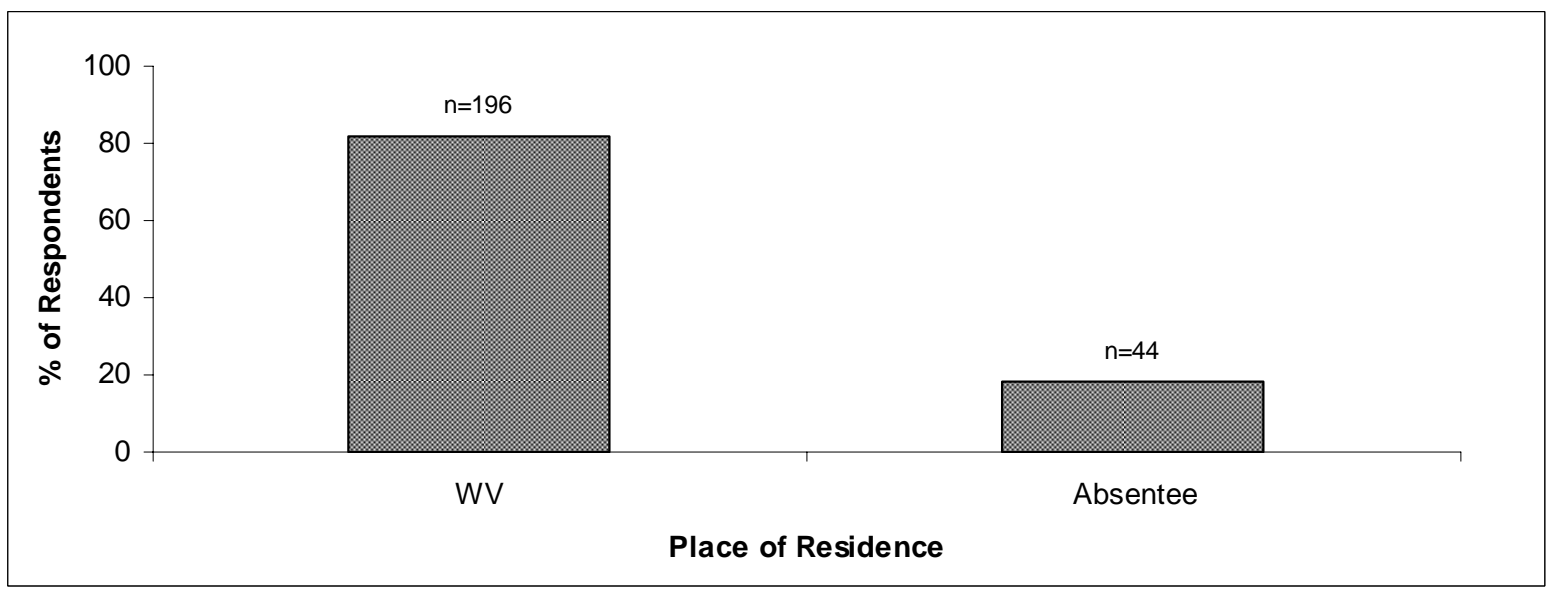

Figure 3. 10: Distribution of NIPF respondents by place of residence, West Virginia, 2005 $(n=240)$.

\subsubsection{Landowner Objectives}

Landowners were presented with 9 possible reasons for owning their forestland: timber for sale, wood for personal use, wildlife, recreation, aesthetics, residence, land investment, water quality, and non-timber forest products (NTFPs). They were then asked to rank these objectives by level of importance. Aesthetics ranked the highest as a reason for owning forestland among the respondents, followed closely by residence, recreation, and wildlife (Table 3.2). Land investment and water quality were also perceived to be more important 
reasons than timber for sale. Timber for sale and wood for personal use only ranked $7^{\text {th }}$ and $8^{\text {th }}$, respectively. Non-timber forest products were perceived to be the least important reason for forestland ownership.

Table 3. 2: The relative importance of reasons for owning a forest land for NIPF survey respondents, West Virginia, 2005.

\begin{tabular}{lrrrrr}
\hline \multicolumn{1}{c}{ Objectives } & $\begin{array}{c}\text { Very } \\
\text { Important } \\
\text { (\%) }\end{array}$ & $\begin{array}{c}\text { Important } \\
\text { (\%) }\end{array}$ & $\begin{array}{c}\text { Not very } \\
\text { important (\%) }\end{array}$ & $\begin{array}{c}\text { Not at all } \\
\text { Important (\%) }\end{array}$ & $\begin{array}{c}\text { Total } \\
\text { (\%) }\end{array}$ \\
\hline Aesthetics & 47.06 & 18.14 & 12.25 & 22.55 & 100 \\
Hunting & 40.00 & 20.91 & 12.27 & 26.82 & 100 \\
Land Investment & 30.70 & 21.86 & 20.00 & 27.44 & 100 \\
NTFPs & 4.37 & 10.19 & 11.65 & 73.79 & 100 \\
Recreation & 43.46 & 23.83 & 12.62 & 20.09 & 100 \\
Residence & 44.55 & 14.22 & 9.00 & 32.23 & 100 \\
Timber for sale & 17.43 & 12.84 & 14.22 & 55.50 & 100 \\
Water Quality & 14.69 & 16.11 & 21.80 & 47.39 & 100 \\
Wood for personal use & 26.96 & 24.02 & 13.24 & 35.78 & 100 \\
\hline
\end{tabular}

Though timber was not thought to be an important reason for owning the forestland by majority of the respondents, the $17 \%$ of the respondents who had reported timber to be one of the important reasons owned nearly 97\% (i.e., 951,309 acres) of the total forestland reported (Figure 3.11). Respondents who thought land investment as an important reason for owning the forestland owned $95 \%$ of the total forestland reported. While aesthetics was the top most reason for owning the forestland, these portion of the respondents owned only $16 \%$ of the total forestland reported. 


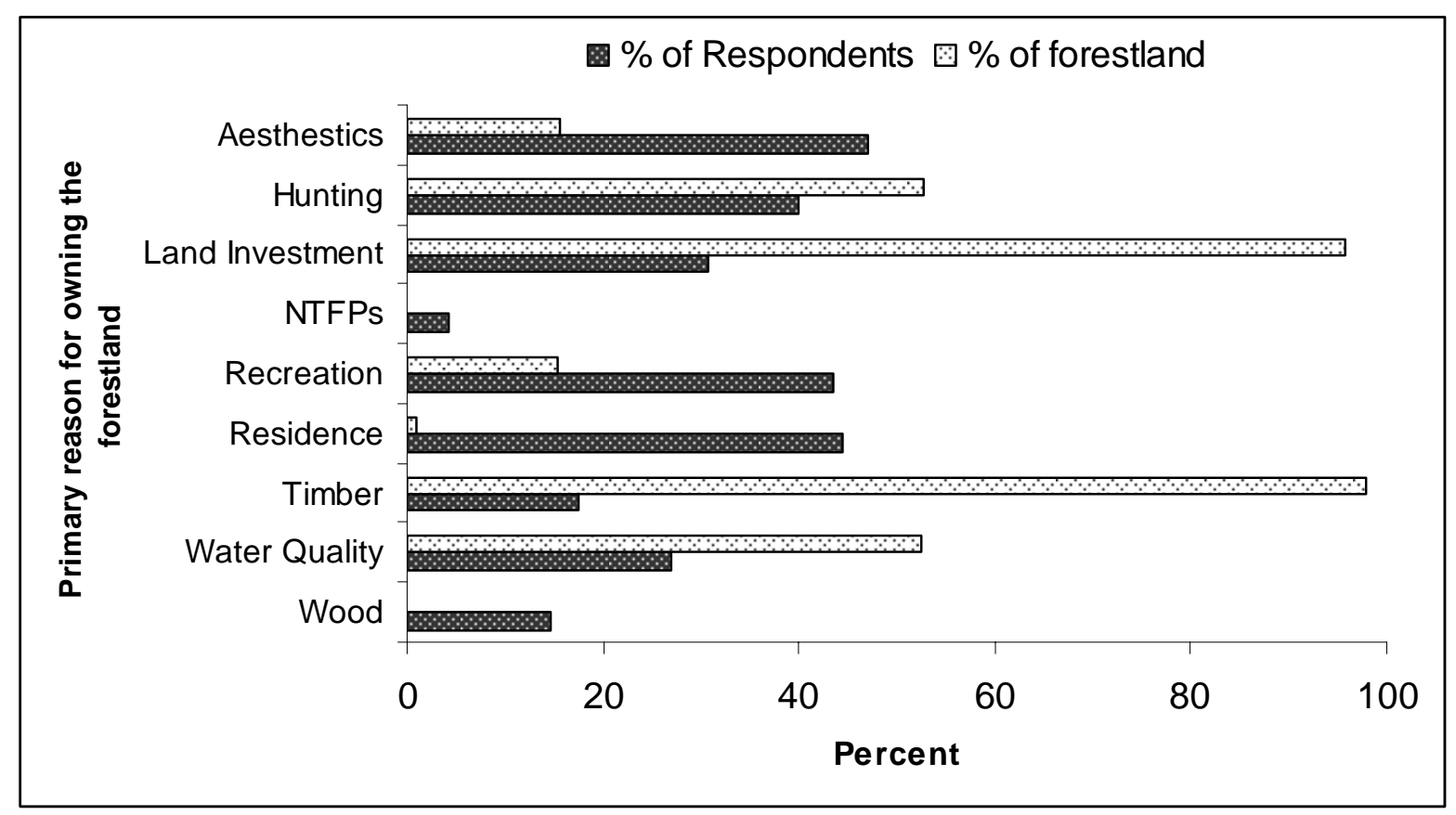

Note: Sum of the responses exceed the no. of responses since respondents chose more than one option. Figure 3. 11: Primary reason for owning the forestland by percentage of owners and ownership size, West Virginia, 2005 ( $n=240)$.

\subsubsection{Forest Management and Investment}

Majority (74\%) of the respondents managed their forestland on their own while $17 \%$ had no one to manage their forestland (Figure 3.12). Only about 8\% of the respondents had sought the help of professional foresters. Of these landowners, majority sought the help of consulting foresters. Even though very few of the landowners sought the help of professional foresters in managing their forestlands, professional foresters managed $97 \%$ of the total forestland owned by the respondents and consulting foresters managed the highest proportion of the forestland (81\%) (Table 3.3).

With respect to the landowners having a written forest management plan, only $12 \%$ of the landowners had a written forest management plan while the majority (66\%) of the landowners did not have one (Figure 3.13). Majority (71\%) of the landowners who had a written management plan confirmed that they followed the treatments prescribed in the 
management plan (Figure 3.14). Of the landowners who did not have a written management plan, 39\% were interested in having a written forest management plan for their property (Figure 3.15).

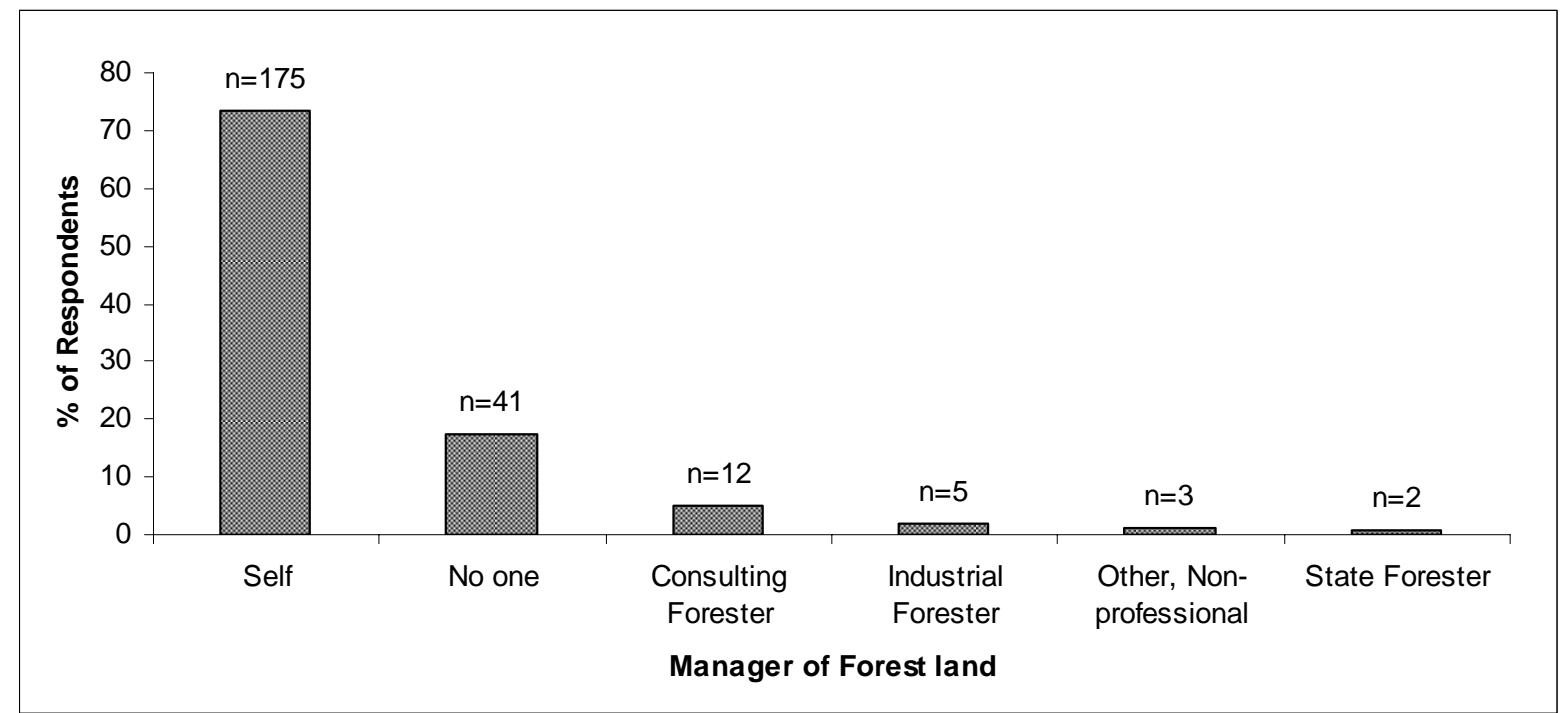

Figure 3. 12: Manager of the forestland owned by NIPF survey respondents, West Virginia, $2005(n=238)$.

Table 3. 3: Acreage owned by the different managers of the NIPF forestlands, West Virginia, 2005.

\begin{tabular}{lrrrrrr}
\hline Managed by & No. & Mean & Min & Max & Sum & \% of sum \\
\hline Self & 175 & 1 & 153 & 5000 & 26478.18 & 2.73 \\
Industrial Forester & 5 & 96 & 38811 & 135000 & 155246.00 & 15.99 \\
State Forester & 2 & 32 & 680 & 1329 & 1361.00 & 0.14 \\
Consulting Forester & 12 & 27.26 & 65451 & 375000 & 785412.26 & 80.88 \\
Other Non-Professional & 3 & 7 & 31 & 57 & 94.00 & 0.01 \\
No one & 44 & 0.5 & 59 & 700 & 2438.89 & 0.25 \\
No Answer & 3 & 0.05 & 1 & 4 & 5.05 & 0.00 \\
\hline Total & 244 & 23.40 & 1 & 375000 & 971035.38 & 100.00 \\
\hline
\end{tabular}




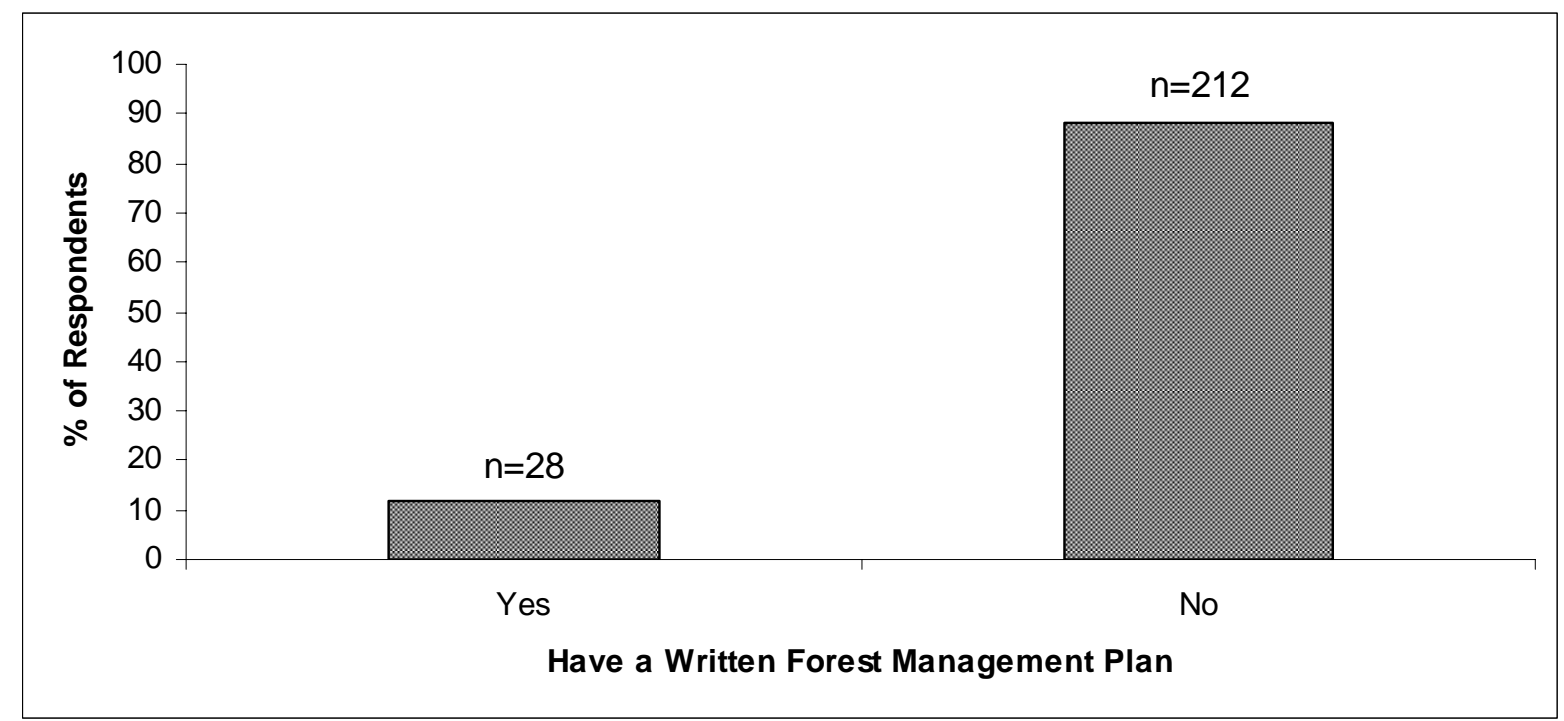

Figure 3. 13: Distribution of NIPF survey respondents by whether a written forest management had been prepared for their forest property, West Virginia, $2005(n=240)$.

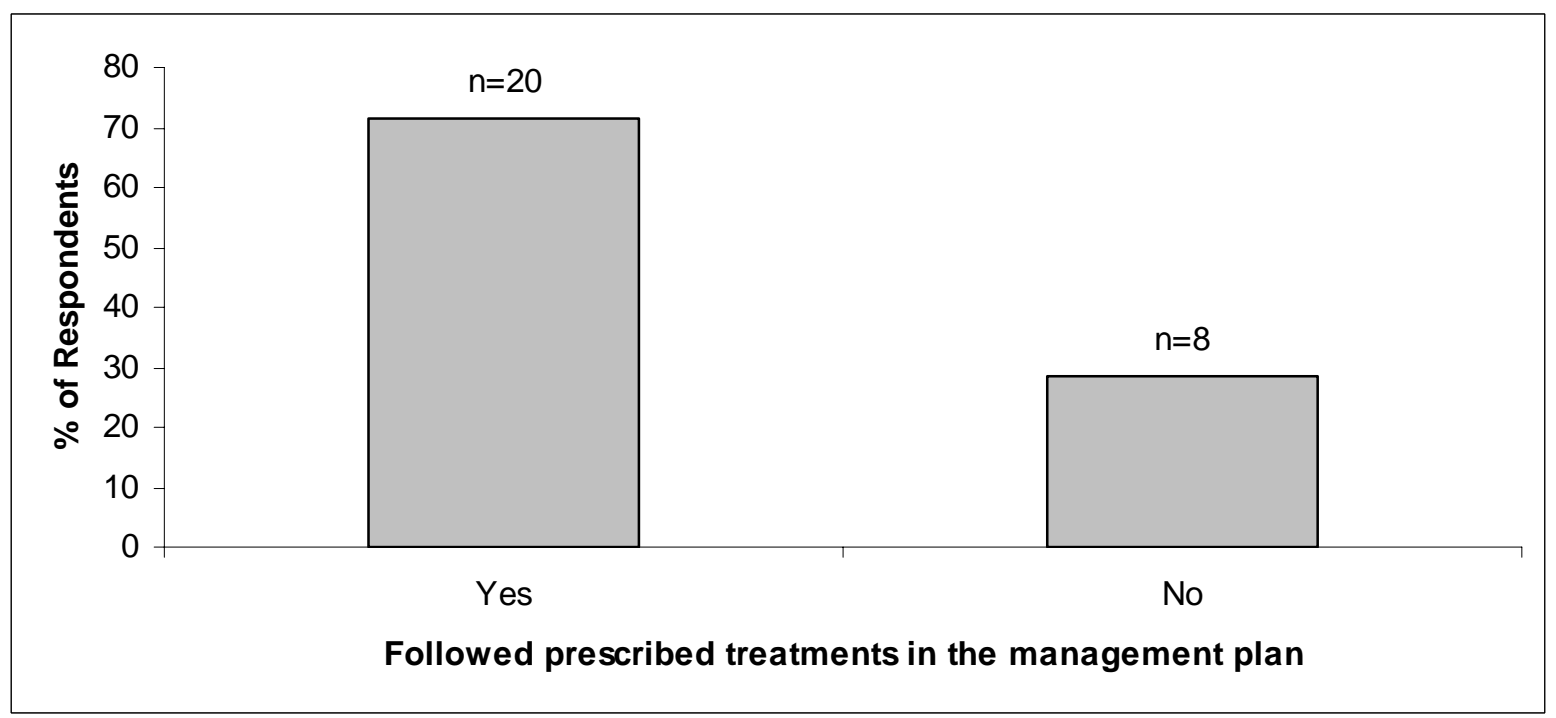

Figure 3. 14: Distribution of NIPF survey respondents who have a written forest management plan by whether they have followed the prescribed treatments in the management plan, West Virginia, 2005 ( $\mathrm{n}=28)$. 


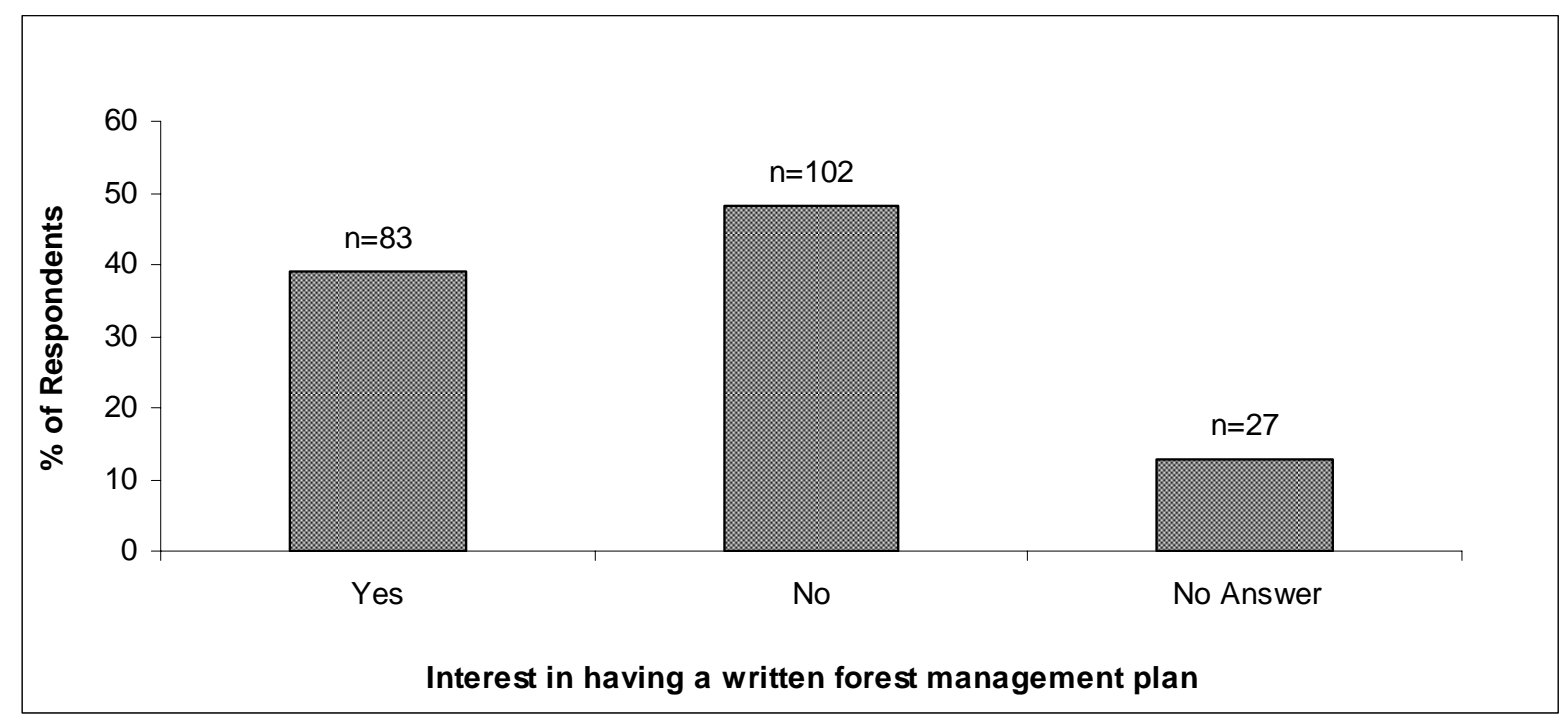

Figure 3. 15: Distribution of NIPF survey respondents by their interest in obtaining a written forest management plan for their forest property, West Virginia, $2005(n=244)$.

The NIPF landowners were also asked how taxes affected their forest management decisions and the use of their timber land. Majority (66\%) of the respondents responded that taxes did not have any influence on their forest management decisions (Figure 3.16).

However there were respondents who felt that taxes did affect the management and use of their forest land. Some respondents (17\%) responded that taxes promoted harvesting mature timber and some (14\%) also thought taxes promoted forest management activities. Others (14\%) thought taxes made them think about selling the property (Figure 3.16).

Of the various tax programs available, the respondents considered property tax to have the most effect on the management and use of their timberland property (Figure 3.17). The property taxes paid by the respondents in 2004 showed that majority (67\%) of the landowners paid less than $\$ 10$ per acre while approximately $7 \%$ of the respondents paid more than $\$ 100$ per acre (Table 3.4). Of the 8 landowners who reported paying more than $\$ 100$ per acre as property tax, 7 of them have reported to own less than 10 acres of forestland. Also, 6 of the landowners have reported residing on the forest property itself. So, the property taxes 
paid might have also included the value of the house located within the forest parcel along with the forestland value. The average property tax paid by the respondents was found to be \$2.11 per acre.

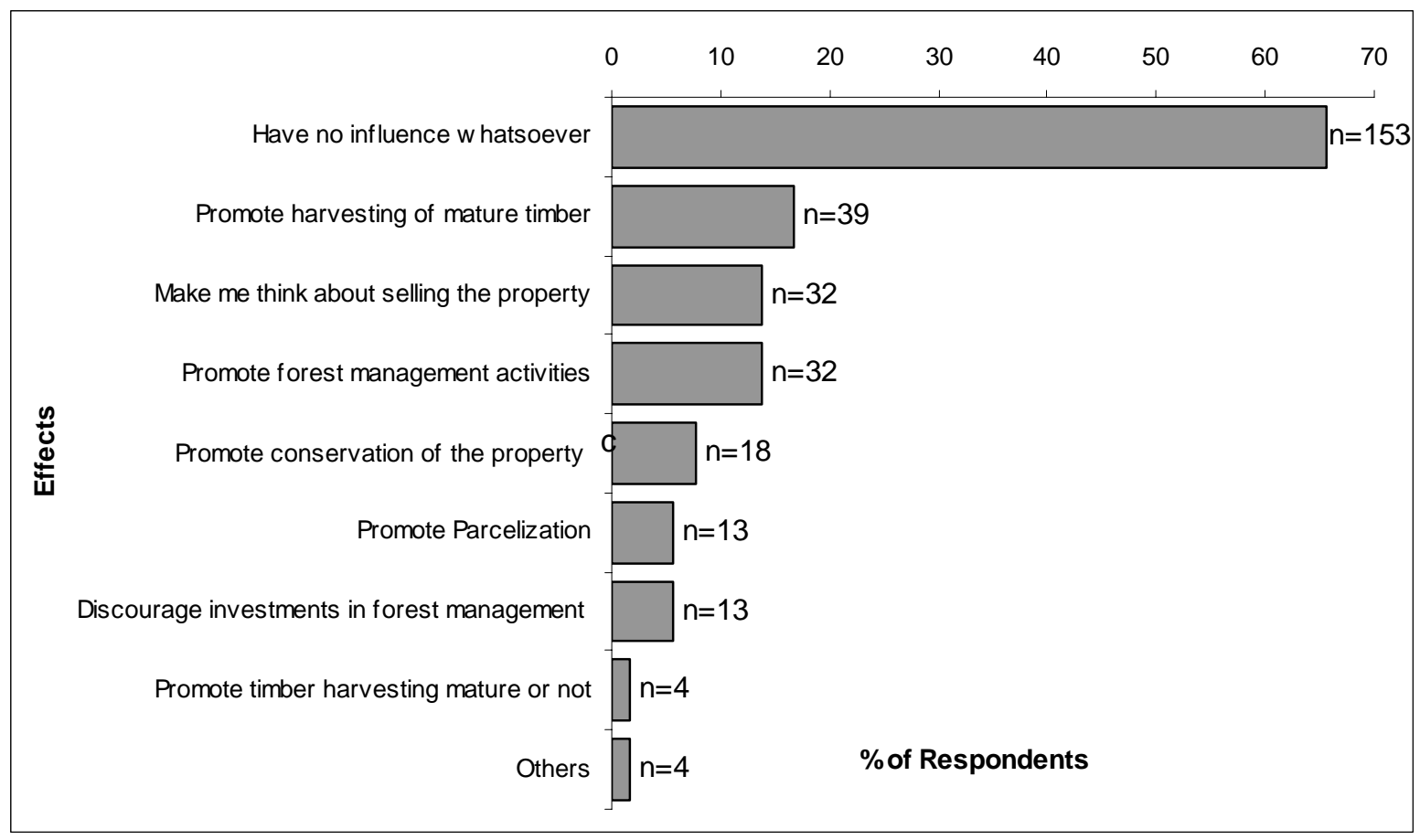

Note: Sum of the responses exceed the no. of responses since respondents chose more than one option. Figure 3. 16: Perceived effect of taxes on the management and use of the forest land by the NIPF survey respondents, West Virginia, 2005 ( $n=233)$.

The NIPF landowners were also asked whether they have had their forestland and timber appraised to see if the landowners knew how much their forestland and timber were worth. Only 8\% of the respondents have had their forestland appraised (Figure 3.18) and only $9 \%$ of the respondents have had their timber appraised (Figure 3.19). Majority of the respondents (53\%) who have had their forestland appraised have their forestland valued at more than $\$ 1000$ per acre (Table 3.5). Similarly, majority of the respondents (65\%) who had not had their forestland appraised indicated that their forestland was worth more than $\$ 1000$ per acre (Table 3.5). Majority of the respondents (37\%) who have had their timber appraised indicated that their timber was worth $\$ 501-\$ 1000$ per acre (Table 3.6). However majority of 
the respondents (46\%) who have not had appraised their timber indicated an estimated timber value greater than $\$ 3000$ per acre (Table 3.6).

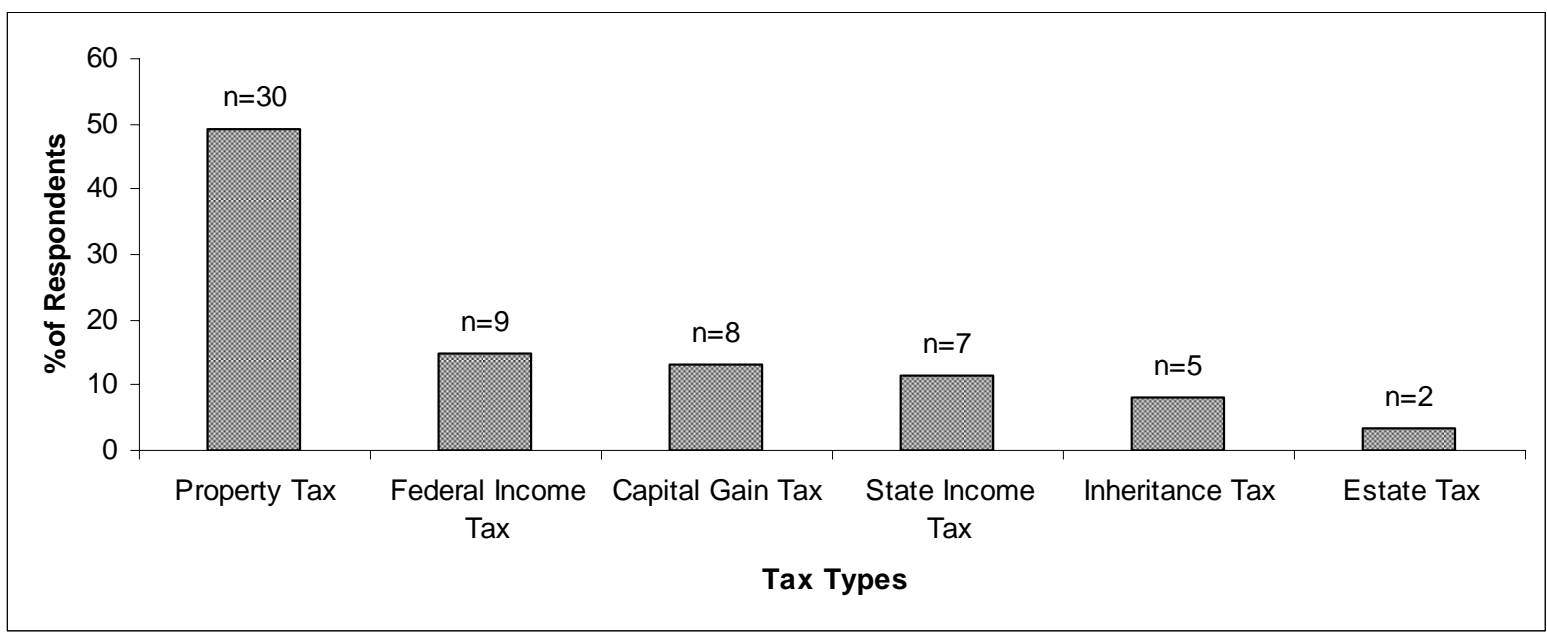

Figure 3. 17: Distribution of NIPF survey respondents by tax programs affecting forest management decisions, West Virginia, $2005(n=61)$.

Table 3. 4: Summary of the expenditures per acre in property taxes for the NIPF survey respondents' forestlands in 2004, West Virginia.

\begin{tabular}{lrr}
\hline Tax (\$) & Frequency & Percentage \\
\hline$<\$ 10$ & 80 & 66.67 \\
$\$ 10-\$ 49$ & 29 & 24.17 \\
$\$ 50-\$ 99$ & 3 & 2.50 \\
$>\$ 100$ & 8 & 6.67 \\
Total & 120 & 100.00 \\
\hline
\end{tabular}

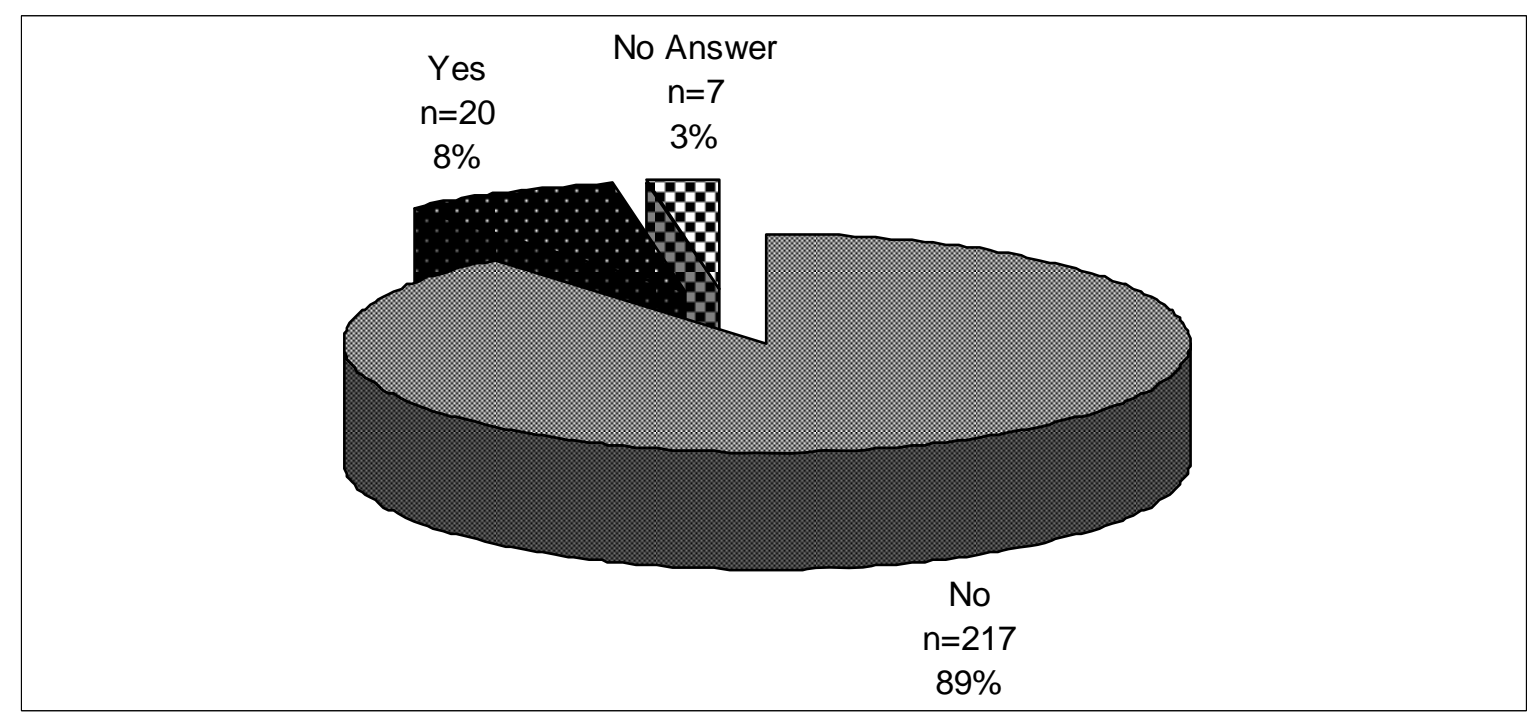

Figure 3. 18: Distribution of NIPF survey respondents by whether they have had their forest land appraised, West Virginia, $2005(\mathrm{n}=244)$. 


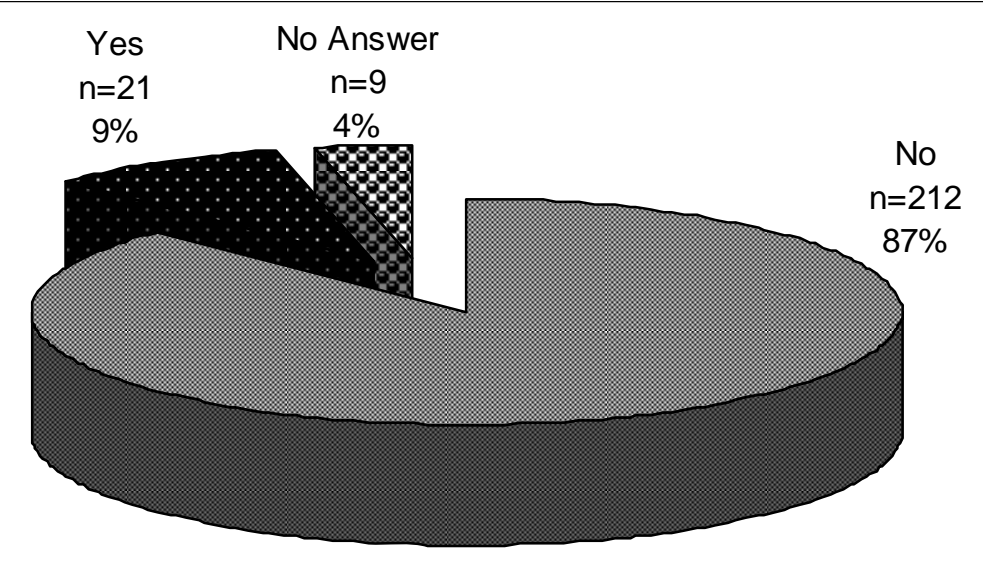

Figure 3. 19: Distribution of NIPF survey respondents by whether they have had their timber appraised, West Virginia, $2005(\mathrm{n}=244)$.

Table 3. 5. Appraised and estimated values of the forest land per acre owned by the NIPF survey respondents, West Virginia, 2005.

\begin{tabular}{lrrrr}
\hline & \multicolumn{3}{c}{ Appraised } & \multicolumn{2}{c}{ Estimated } \\
\cline { 2 - 5 } \multicolumn{1}{c}{ Land Value (\$) } & Frequency & $\mathbf{\%}$ & Frequency & \% \\
\hline $0-200$ & 4 & 21.05 & 4 & 5.13 \\
$201-400$ & 0 & 0.00 & 5 & 6.41 \\
$401-600$ & 3 & 15.79 & 7 & 8.97 \\
$601-800$ & 1 & 5.26 & 4 & 5.13 \\
$801-1000$ & 1 & 5.26 & 7 & 8.97 \\
$>1000$ & 10 & 52.63 & 51 & 65.38 \\
Total & 19 & 100.00 & 78 & 100.00 \\
\hline
\end{tabular}

Table 3. 6. Appraised and estimated values of the timber per acre owned by the NIPF survey respondents, West Virginia, 2005.

\begin{tabular}{lrrrr}
\hline & \multicolumn{2}{c}{ Appraised } & \multicolumn{2}{c}{ Estimated } \\
\cline { 2 - 5 } Timber Value (\$) & No. & \% & No. & \% \\
\hline $0-500$ & 4 & 21.05 & 18 & 21.95 \\
$501-1000$ & 7 & 36.84 & 12 & 14.63 \\
$1001-1500$ & 2 & 10.53 & 1 & 1.22 \\
$1501-2000$ & 2 & 10.53 & 9 & 10.98 \\
$2001-2500$ & 0 & 0.00 & 2 & 2.44 \\
$2501-3000$ & 1 & 5.26 & 2 & 2.44 \\
$>3000$ & 3 & 15.79 & 38 & 46.34 \\
Total & 19 & 100.00 & 82 & 100.00 \\
\hline
\end{tabular}


The study also looked at the problems encountered by the landowners on their forest property. The most common problem reported by the landowners was trespassing, followed by poaching, trash dumping and deer (Figure 3.20).

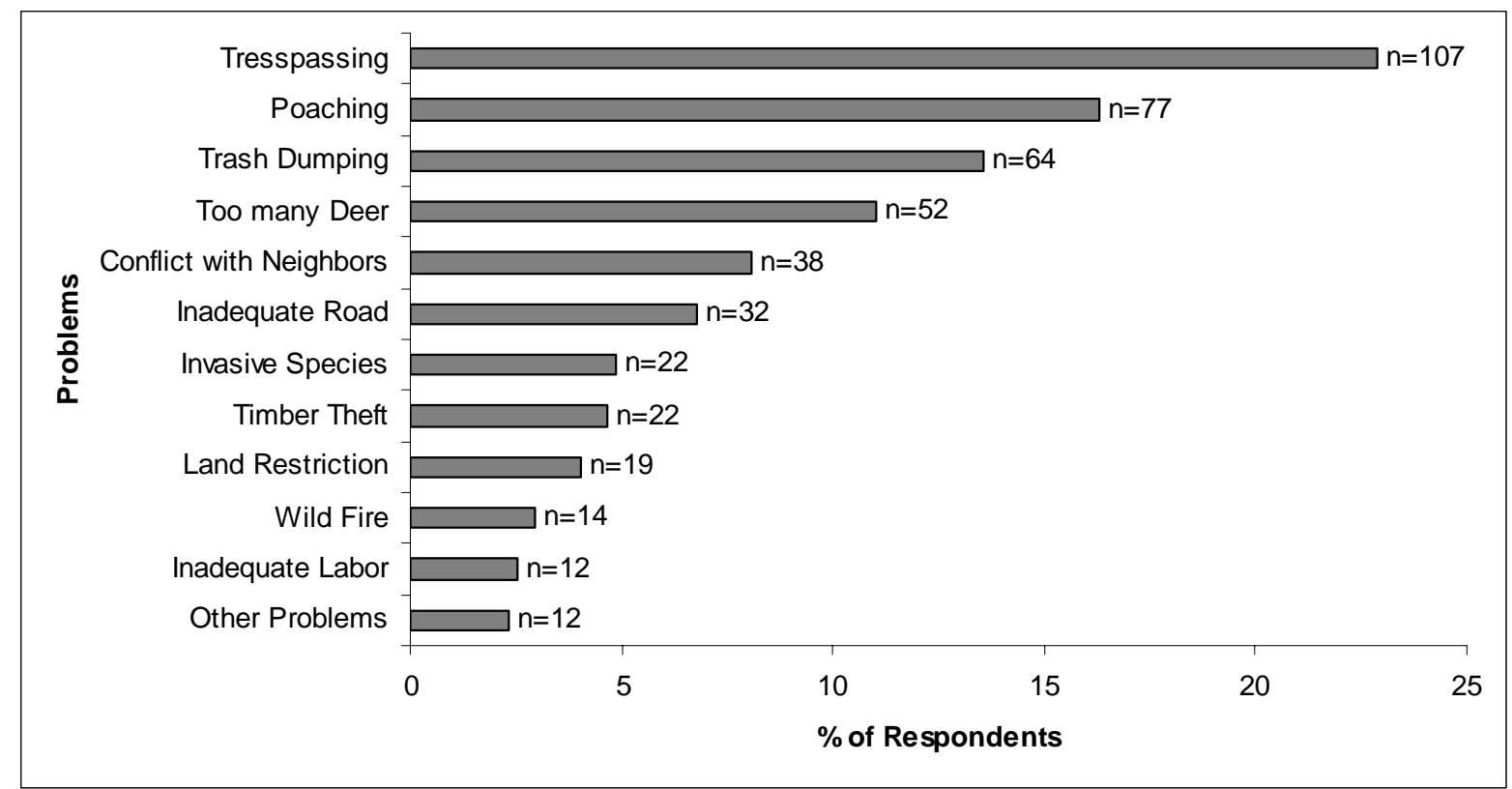

Note: Sum of the responses exceed the no. of responses since respondents chose more than one option. Figure 3. 20: Problems typically encountered by NIPF survey respondents in their forest property, West Virginia, $2005(n=221)$.

The landowners were also asked if they were engaged in any of the forest management activities: timber harvesting, tree planting, herbicide application, fertilization, thinning, road construction, road maintenance, survey, access control, grapevine control, timber stand improvement, wildlife habitat improvement, recreation improvement, and other related activities. Specifically, landowners were asked to report the activities that they carried out in 2004 and in previous years. Less than 13\% of the landowners had carried out any type of forest management activity in 2004. Road maintenance was the most commonly practiced forest management activity followed by timber harvesting, wildlife habitat improvement, and recreation improvement (Figure 3.21). Prior to 2004, 50\% of the landowners had practiced some type of forest management activity in their property. Timber harvest and tree planting 
were the most practiced forest management activity followed by road construction, recreation improvement, road construction and maintenance (Figure 3.21).

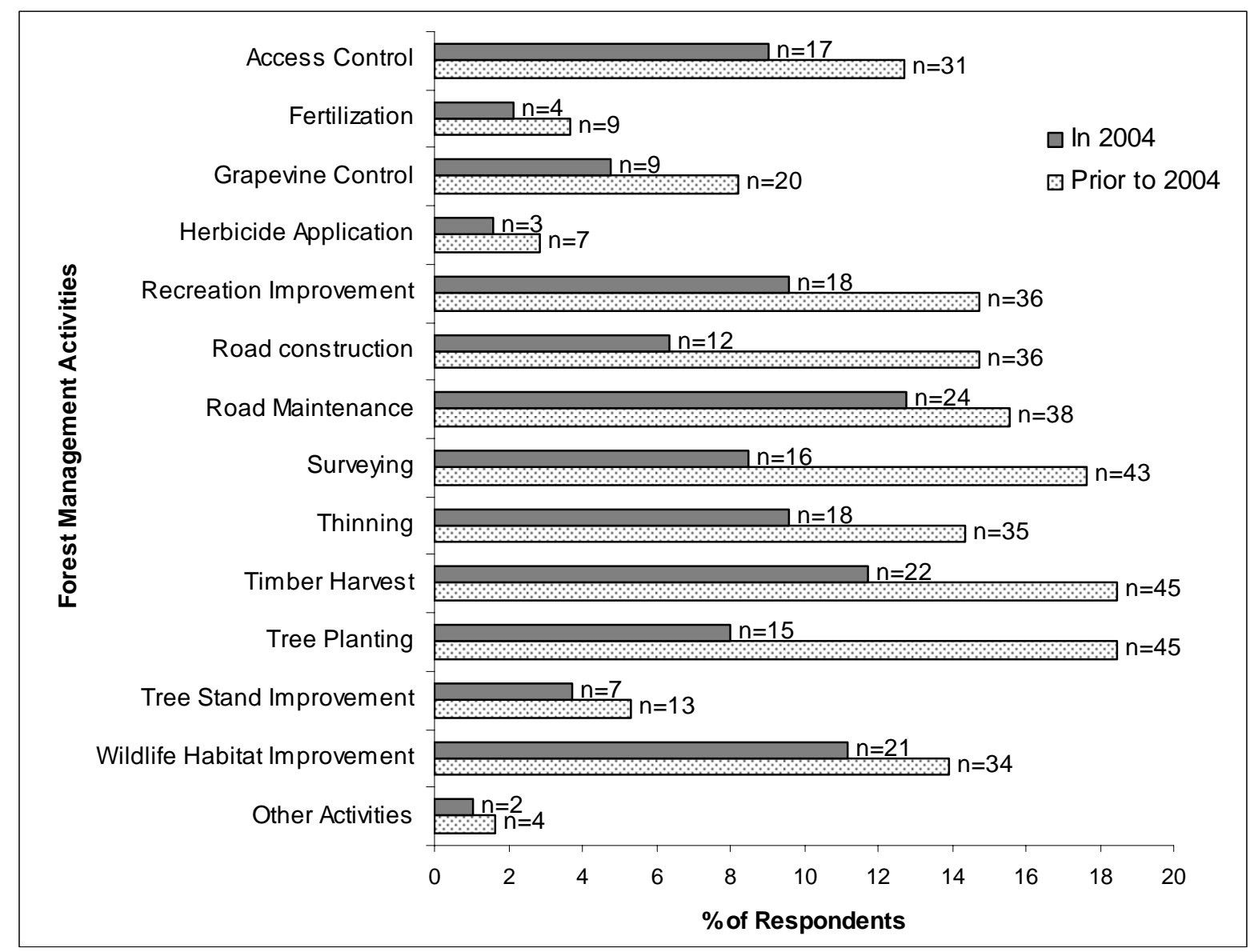

Note: Sum of the responses exceed the no. of responses since respondents chose more than one option. Figure 3. 21: Percentage of NIPF survey respondents carrying out different types of forest management activities prior to 2004 and in 2004, West Virginia $(\mathrm{n}=181)$.

\subsection{Harvesting and Sale}

Majority (77\%) of the landowners had not harvested timber in the past 5 years with only $21 \%$ harvesting the timber (Figure 3.22). The most common reasons for harvesting the timber reported by the respondents were: the timber was mature (24\%), to improve the quality of remaining trees (14.84\%), received good prices for the timber (14.06\%), and salvaged the value of timber of forest products that had been damaged (13\%) (Figure 3.23). Majority (44\%) of the respondents had harvested their timber most recently in 2004 (Figure 
3.24). Select cut (56\%) was the frequently used method for harvesting the timber by the respondents (Figure 3.25). The average acres harvested using select cut was 14.62 acres (Table 3.7).

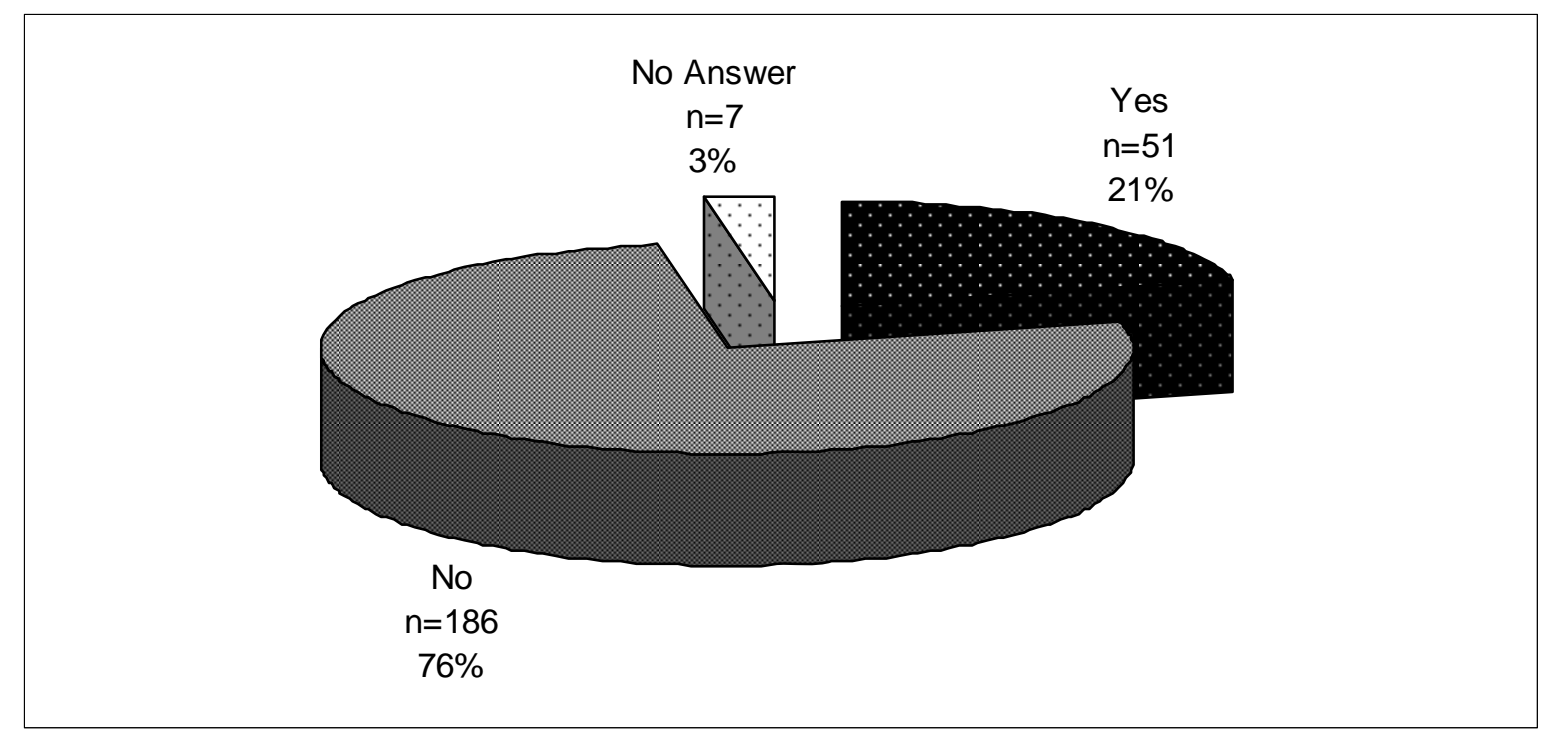

Figure 3. 22: Distribution of NIPF survey respondents by whether they have harvested or sold timber in between 2000 and 2005, West Virginia $(\mathrm{n}=244)$.

The NIPF survey landowners were also asked whether they had used the assistance or advice of a professional forester during their most recent timber sale. Only $8 \%$ of the respondents responded that they had used the advice or assistance of a professional forester (Figure 3.26). Of the landowners who had used the advice or assistance, majority had used the advice or assistance of a state forester (33\%) or a consulting forester (33\%) (Figure 3.27). For the respondents who had not harvested their timber in the past 5 years, almost $50 \%$ of the landowners said that they were not interested in harvesting their timber (Figure 3.28). Lack of knowledge on how to sell the timber and unfamiliarity with buyers or not being able to find the market was reported by about $22 \%$ of the respondents for not harvesting their timber. Half of the respondents also reported that they did not plan on harvesting and selling their 
timber in the future while $34 \%$ reported that their intentions of future timber harvest and sale and $14 \%$ were uncertain (Figure 3.29).

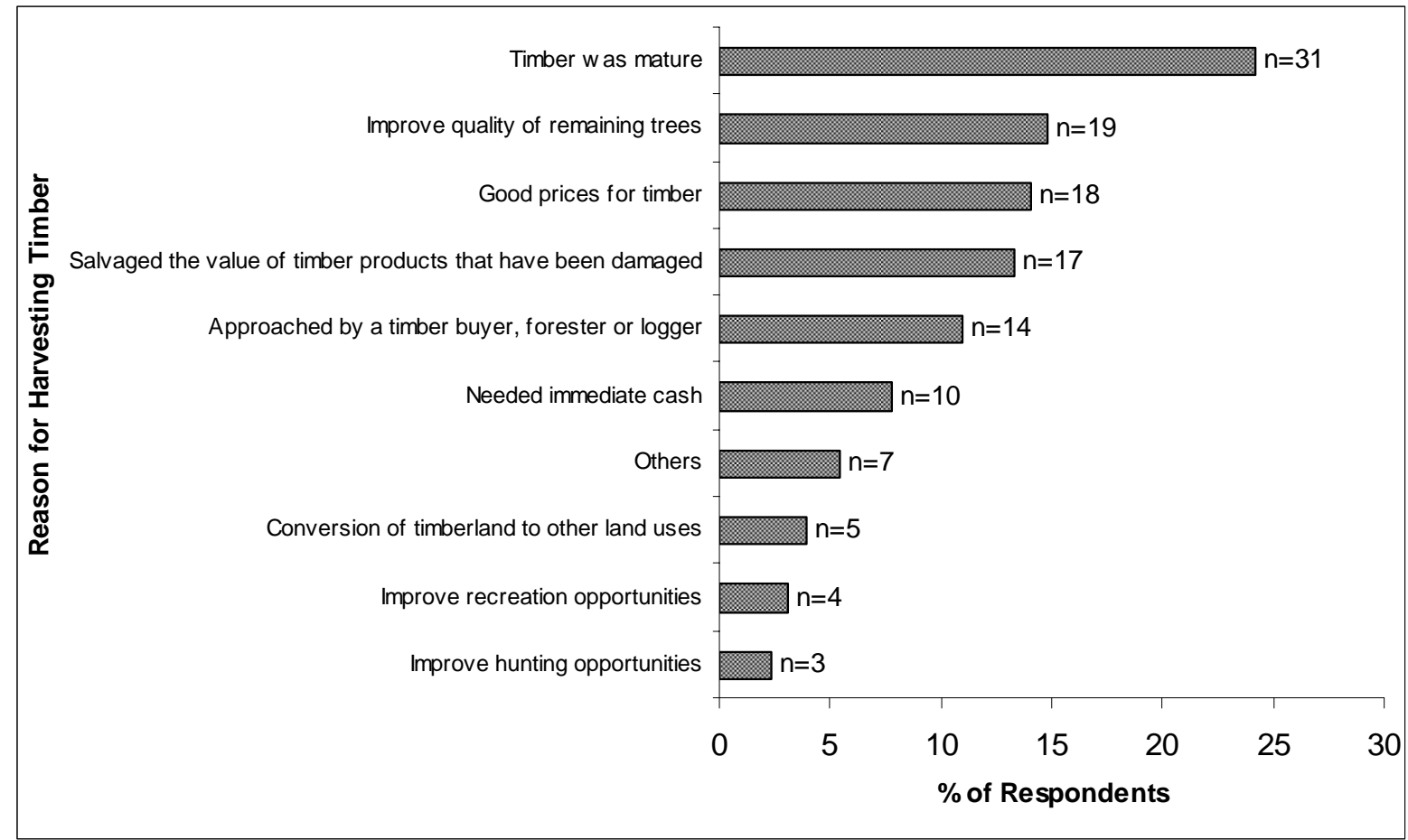

Note: Sum of the responses exceed the no. of responses since respondents chose more than one option.

Figure 3. 23: Reasons for harvest or sale of timber by the NIPF survey respondents between 2000 and 2005, West Virginia (n=239).

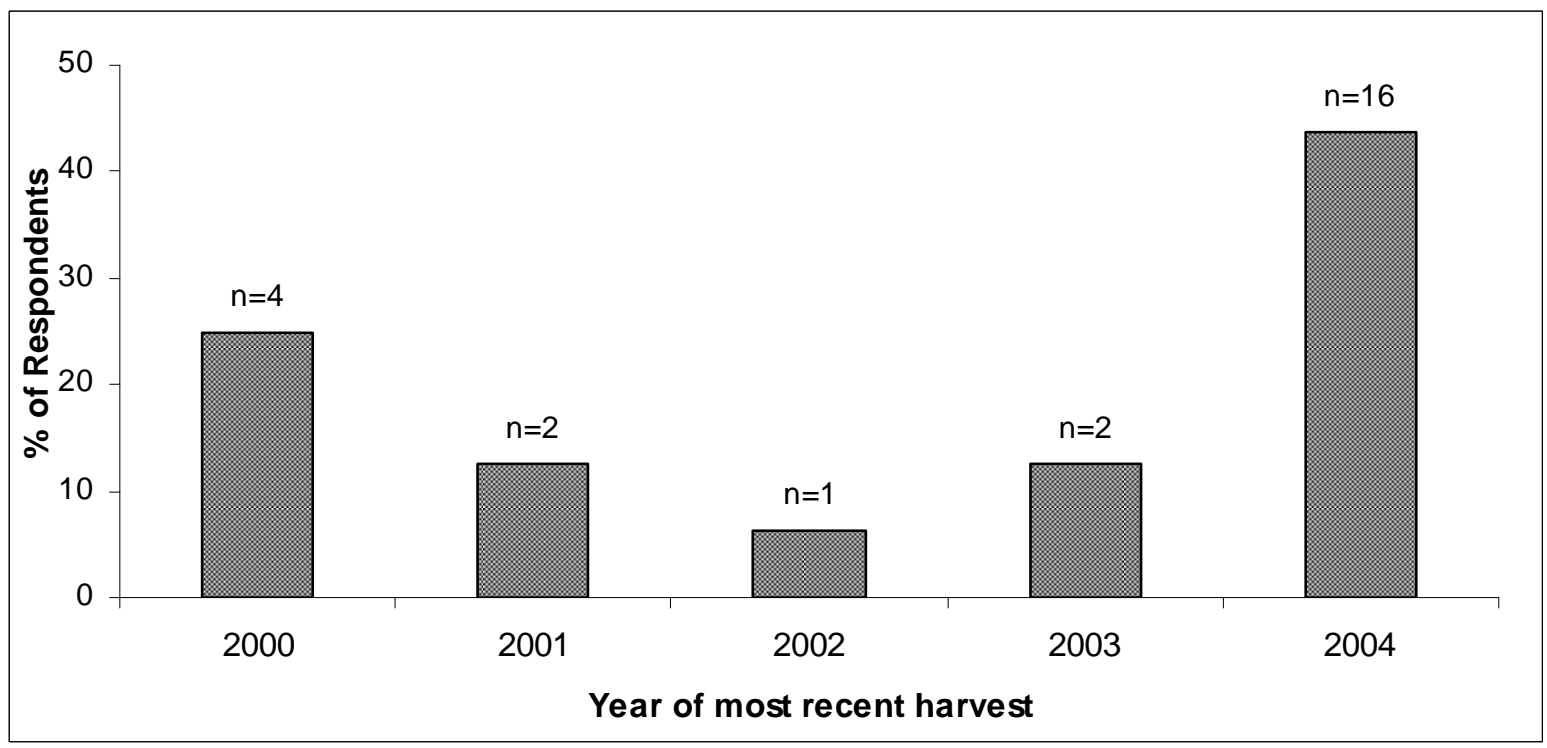

Figure 3. 24: Distribution of NIPF survey respondents by year of most recent harvest, West Virginia, $2005(n=25)$. 
The survey results also showed low level of attendance of the landowners in the educational programs designed for the forest landowners. Only $4 \%$ of the respondents reported to have attended any educational programs designed specially for the forest landowners (Figure 3.34). Most (40\%) of the respondents had attended the educational programs sponsored or co-sponsored by the West Virginia Division of Forestry (Figure 3.35). The survey also asked the topics that the respondents wanted the educational programs to focus on. The respondents were mostly interested in topics related to timber harvesting and sale, best management practices, wildlife management and insects and diseases (Figure 3.36). The respondents also thought that talking to a forester agent or extension agent as the most effect tool in delivering forestry educational materials (Figure 3.37). Conferences, workshops or meetings and pamphlets or newsletters were also thought to be effective tools in delivering the educational materials.

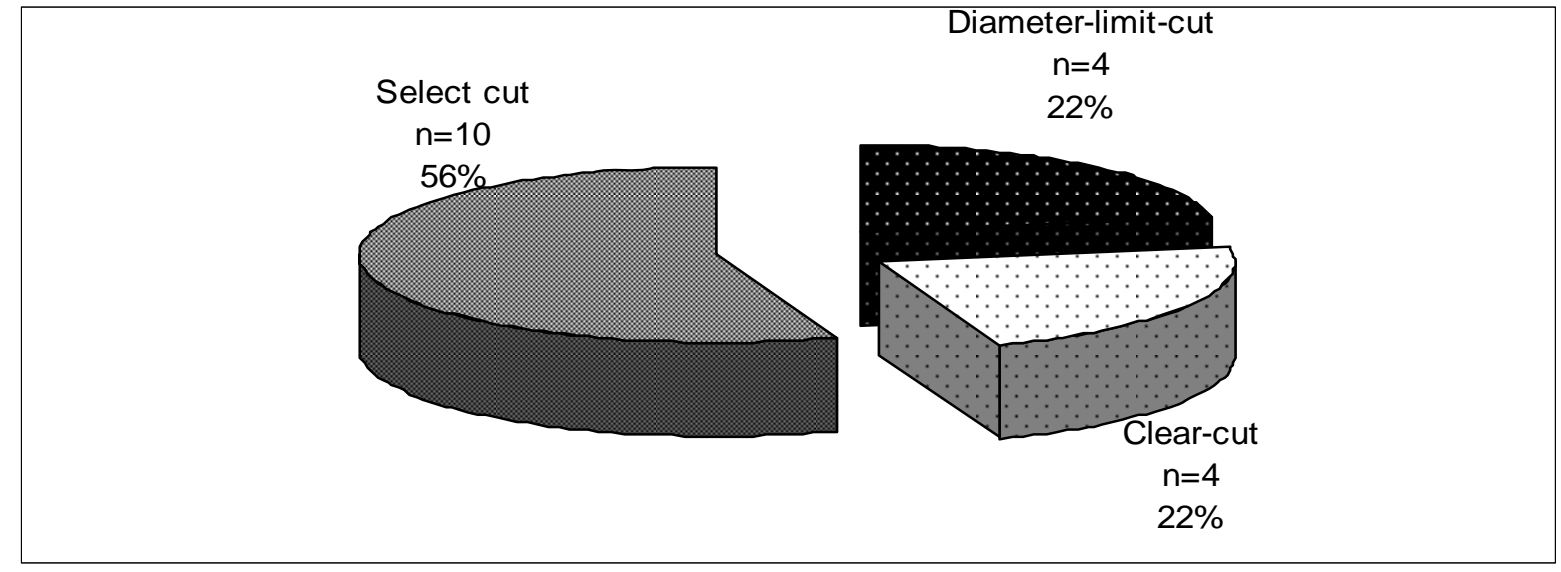

Note: Sum of the responses exceed the no. of responses since respondents chose more than one option. Figure 3. 25: Distribution of NIPF survey respondents by types of harvest method used in the most recent timber harvest, West Virginia, $2005(n=16)$.

Table 3. 7. Acreage harvested in the most recent timber harvest by the NIPF survey respondents, West Virginia, 2005.

\begin{tabular}{lrrrrrr}
\hline \multicolumn{1}{c}{ Harvest Method } & \multicolumn{1}{c}{ Mean } & Std Dev & Minimum & Maximum & Median & Range \\
\hline Clear-cut & 132.50 & 70.67 & 5 & 500 & 12.5 & 495 \\
Diameter-limit-cut & 17.37 & 5.93 & 0.125 & 40 & 12 & 39.875 \\
Select cut & 78.50 & 54.07 & 0.5 & 323 & 31 & 322.50 \\
\hline
\end{tabular}




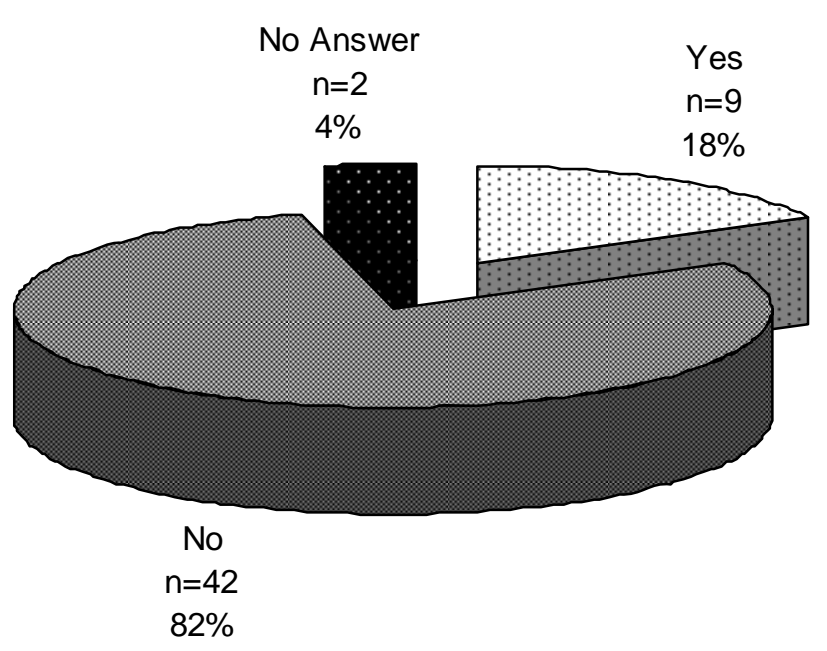

Figure 3. 26. Distribution of NIPF survey respondents by whether they have used the assistance/advice of a professional forester during the most recent timber sale, West Virginia ( $\mathrm{n}=53), 2005$.

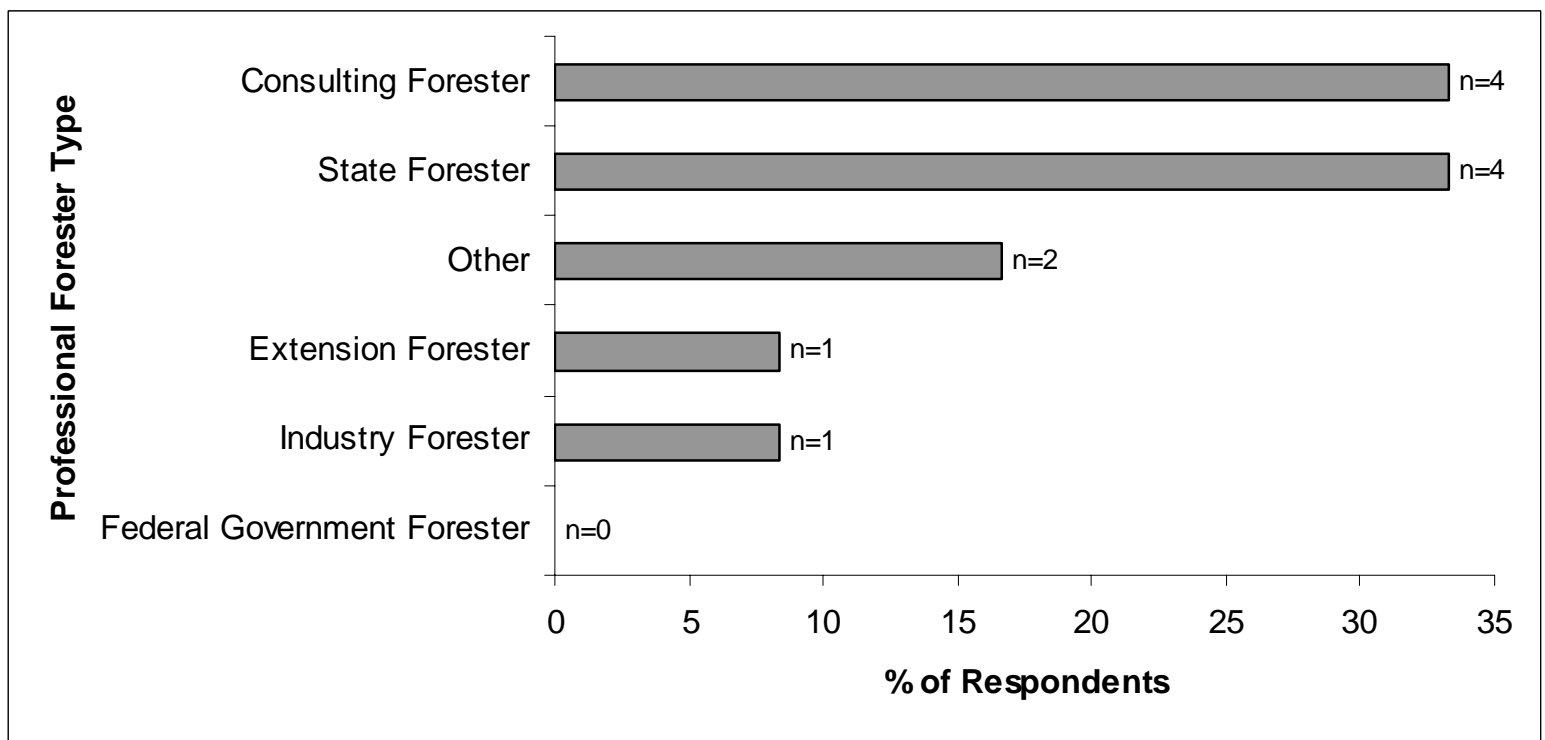

Note: Sum of the responses exceed the no. of responses since respondents chose more than one option. Figure 3. 27: Distribution of NIPF survey respondents by the types of professional forester used during the most recent timber sale, West Virginia, 2005 (n=9). 


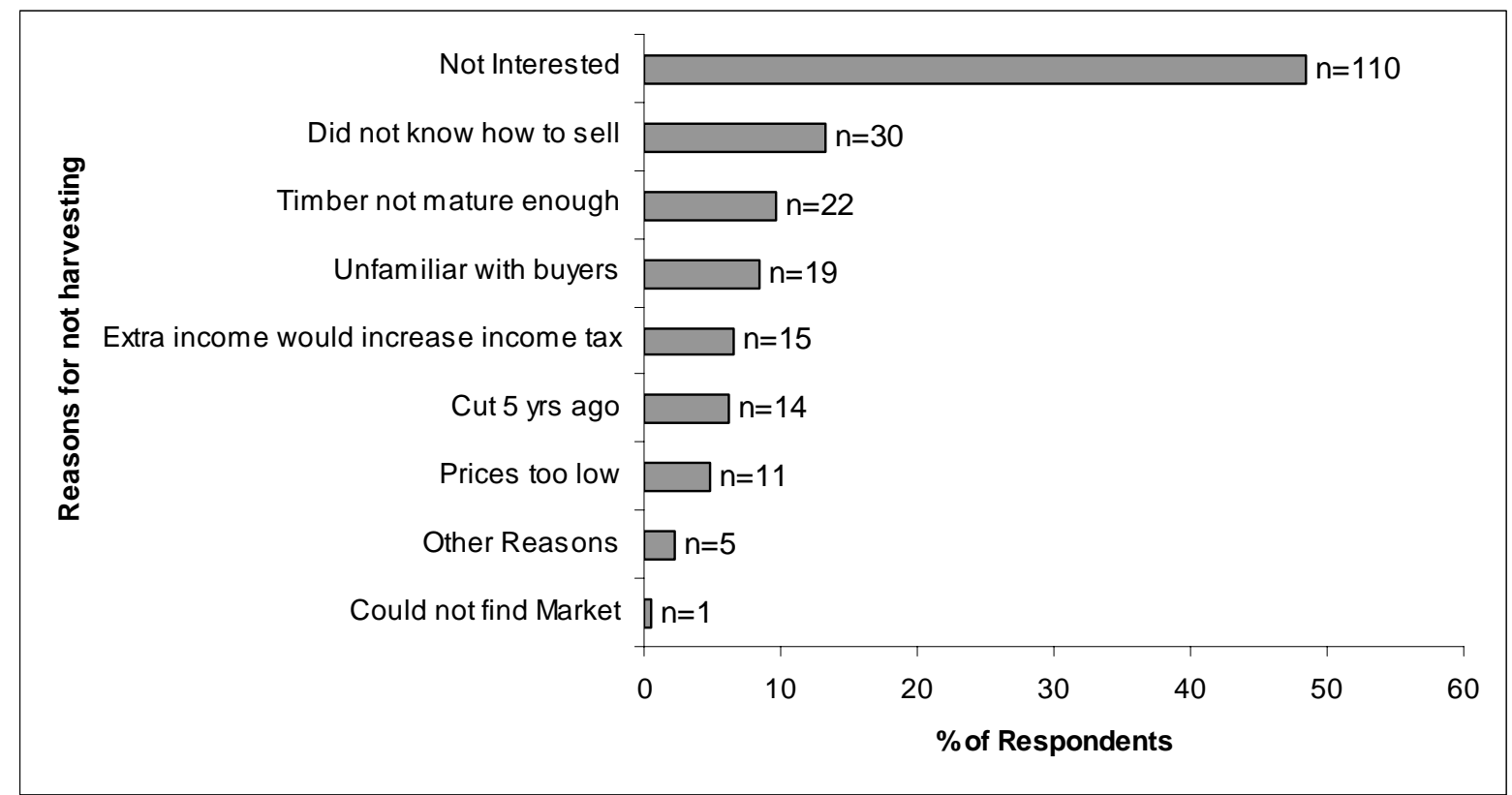

Note: Sum of the responses exceed the no. of responses since respondents chose more than one option.

Figure 3. 28: Reasons for not harvesting or selling timber by NIPF survey respondents, West Virginia, 2005 (n=224).

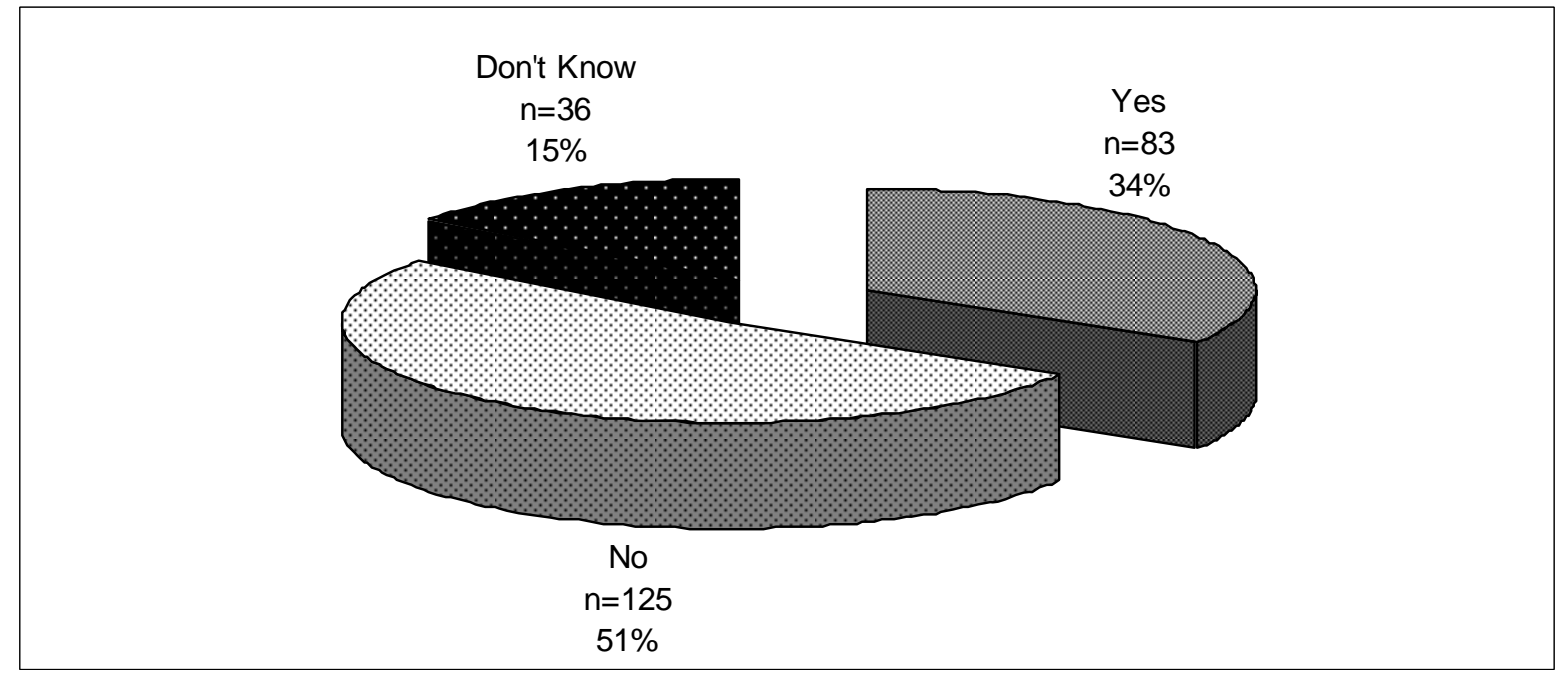

Figure 3. 29: Future timber harvest and sale intentions of NIPF survey respondents, West Virginia, $2005(n=244)$. 


\subsection{Use of Forestry Assistance/Incentive and Educational Programs}

The results of the survey indicate that NIPF respondents have low level of awareness about the forestry assistance or incentive and educational programs that are available to them. A large proportion of the respondents had not responded to the question (57\%) of whether they were aware of any forestry assistance or incentive programs. Of the landowners who had responded, 43\% were aware of one or more of such programs (Figure 3.30): Forest Stewardship Program, Forest Land Enhancement Program, Federal Income Tax Incentives, West Virginia Managed and Timberland's Tax Incentive Program. Of the respondents who were aware of the program, only $30 \%$ of the respondents reported to have used the program (Figure 3.31). The Forest Stewardship Program (37\%) was the most commonly used program (Figure 3.32). Most (70\%) of the respondents were satisfied with the forestry assistance/incentive programs that they had used (Figure 3.33).

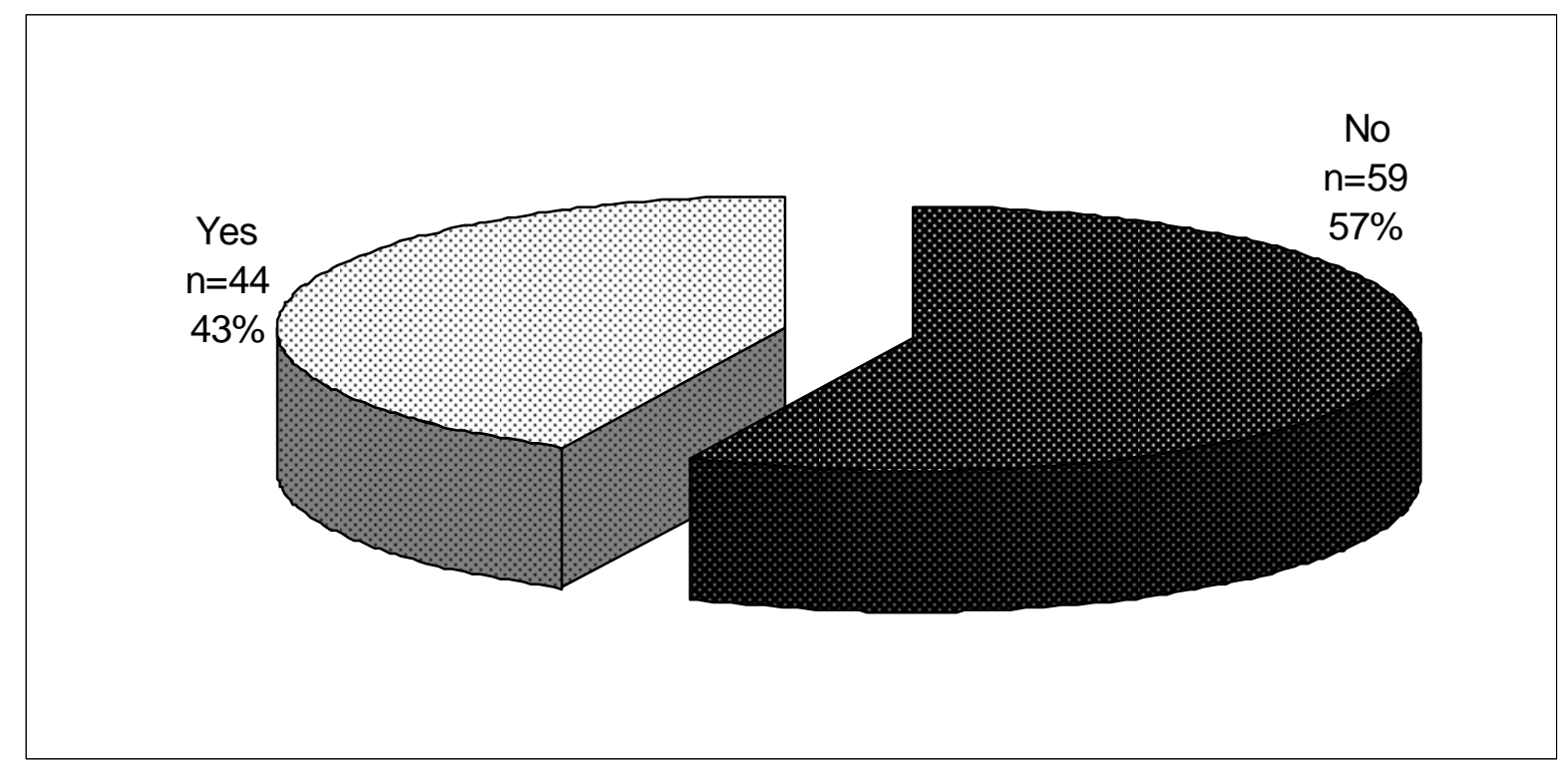

Figure 3. 30: Distribution of the of NIPF survey respondents by how aware they are about existing forestry assistance/incentive programs, West Virginia, 2005 (n=104). 


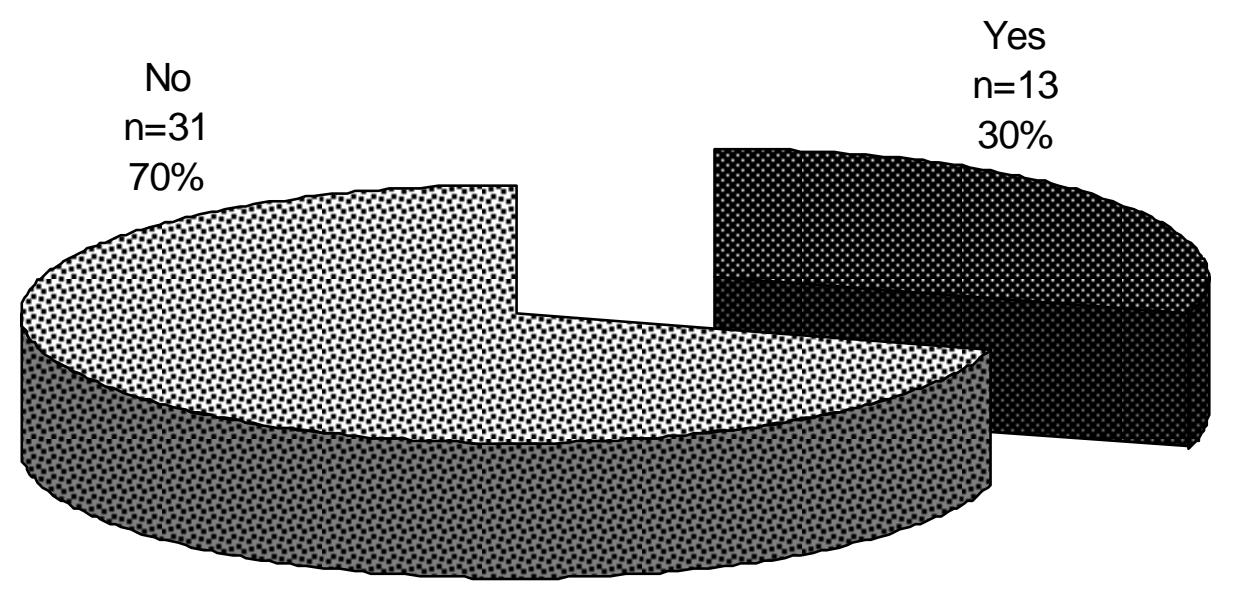

Figure 3. 31: Distribution of the of NIPF survey respondents who were aware of the existing forestry assistance/incentive programs by whether they had used it or not, West Virginia, $2005(n=44)$.

Chi-square tests were conducted to see if the types of forest management activities undertaken by NIPF respondents were related to their awareness about the various forestry assistance/incentive programs. All the forest management activities were shown to be associated with their awareness about the forestry assistance/incentive programs except for road construction, fertilization, wildlife habitat management and recreational improvement (Table 3.8). 
Table 3. 8 Association between the forest management activities that the NIPF respondents conducted in 2004 and their awareness about the forestry incentive/assistance programs, West Virginia.

\begin{tabular}{|c|c|c|c|c|c|}
\hline \multirow[t]{2}{*}{ Activities } & & \multicolumn{2}{|c|}{$\begin{array}{l}\text { Aware of the forestry incentive/assistance } \\
\text { programs }\end{array}$} & \multicolumn{2}{|c|}{$\begin{array}{l}\text { Chi-square } \\
\text { value }\end{array}$} \\
\hline & & Yes (\%) & No(\%) & & \\
\hline \multirow{2}{*}{ Harvest } & Yes & 47.62 & 52.38 & 8.1364 & $\star \star \star *$ \\
\hline & No & 19.59 & 80.41 & & \\
\hline \multirow{2}{*}{ Tree planting } & Yes & 53.33 & 46.67 & 8.489 & $\star \star \star$ \\
\hline & No & 20.13 & 79.87 & & \\
\hline \multirow{2}{*}{ Herbicide application } & Yes & 66.67 & 33.33 & 3.2691 & * \\
\hline & No & 22.29 & 77.71 & & \\
\hline \multirow{2}{*}{ Fertilization } & Yes & 25.00 & 75.00 & 0.0085 & \\
\hline & No & 23.03 & 76.97 & & \\
\hline \multirow{2}{*}{ Thinning } & Yes & 44.44 & 55.56 & 5.1815 & ** \\
\hline & No & 20.53 & 79.47 & & \\
\hline \multirow{2}{*}{ Road construction } & Yes & 25.00 & 75.00 & 0.0269 & \\
\hline & No & 22.93 & 77.07 & & \\
\hline \multirow{2}{*}{ Road maintenance } & Yes & 41.67 & 58.33 & 5.4456 & ** \\
\hline & No & 20.00 & 80.00 & & \\
\hline \multirow{2}{*}{$\begin{array}{l}\text { Survey/Boundary } \\
\text { maintenance }\end{array}$} & Yes & 56.25 & 43.75 & 10.956 & $\star \star \star *$ \\
\hline & No & 19.61 & 80.39 & & \\
\hline \multirow{2}{*}{ Access control } & Yes & 53.33 & 46.67 & 8.489 & $* \star \star$ \\
\hline & No & 20.13 & 79.87 & & \\
\hline \multirow{2}{*}{$\begin{array}{l}\text { Grapevine } \\
\text { control }\end{array}$} & Yes & 55.56 & 44.44 & 5.649 & ** \\
\hline & No & 21.25 & 78.75 & & \\
\hline \multirow{2}{*}{ Timber stand improvement } & Yes & 66.67 & 33.33 & 6.6586 & 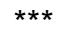 \\
\hline & No & 21.47 & 78.53 & & \\
\hline \multirow{2}{*}{ Wildlife habitat improvement } & Yes & 31.58 & 68.42 & 0.8717 & \\
\hline & No & 22.00 & 78.00 & & \\
\hline \multirow{2}{*}{ Recreational improvement } & Yes & 18.75 & 81.25 & 0.2095 & \\
\hline & No & 23.84 & 76.16 & & \\
\hline
\end{tabular}

* Significant at $10 \%$ level, ** Significant at $5 \%$ level, *** Significant at $1 \%$ level 


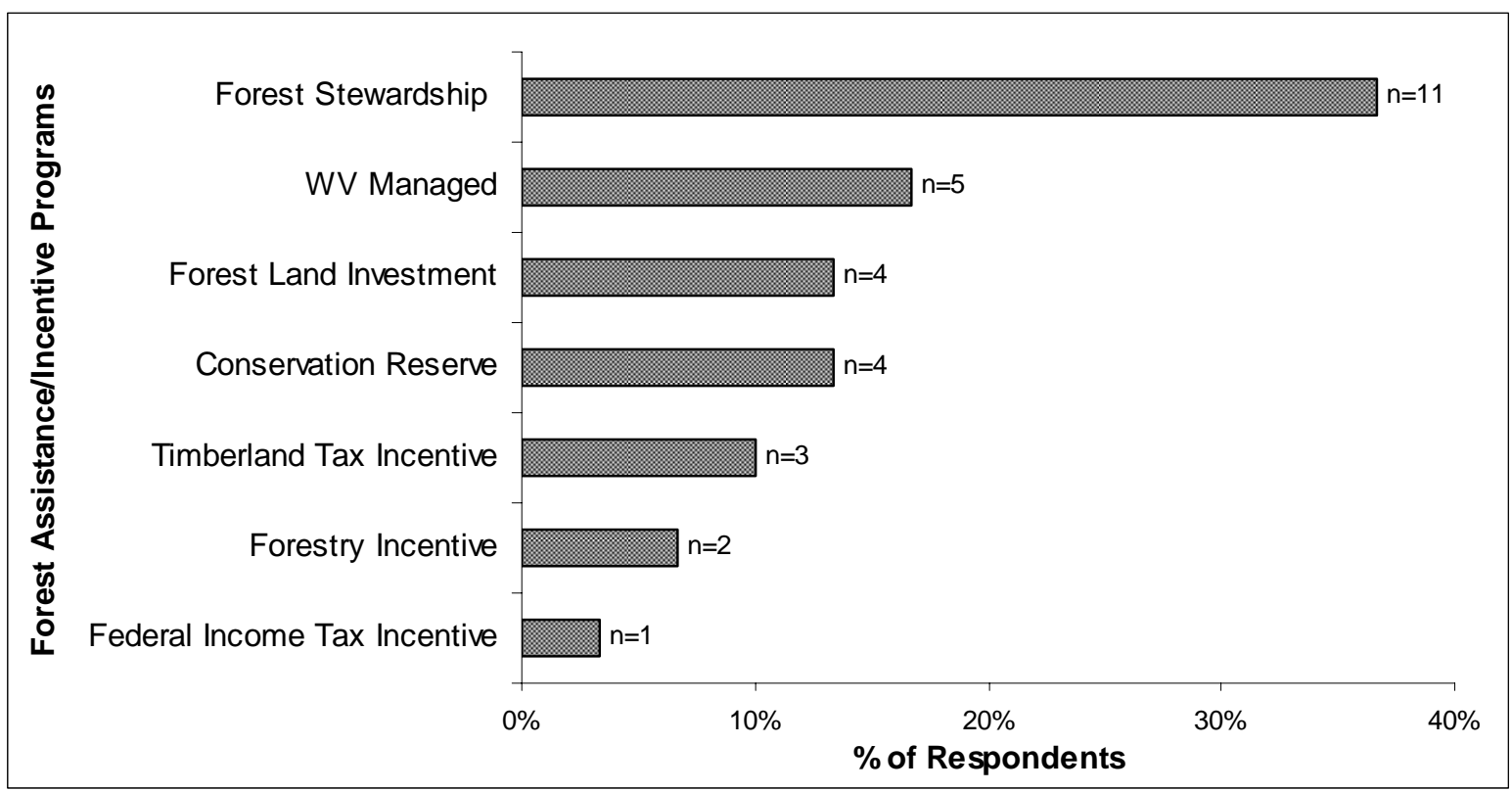

Figure 3. 32: Use of existing forestry assistance/incentive programs by the NIPF survey respondents, West Virginia, $2005(n=30)$.

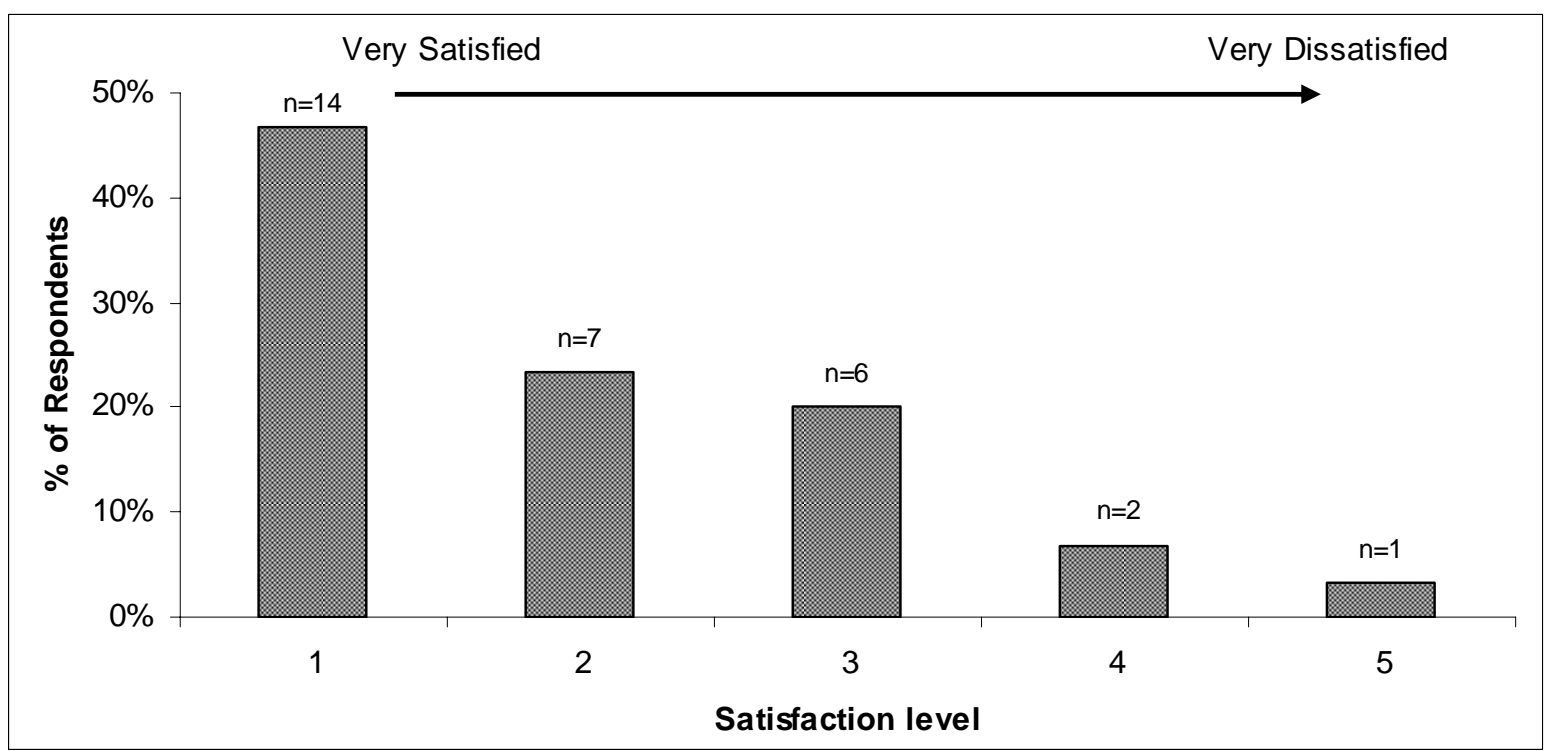

Figure 3. 33: Satisfaction level of the NIPF survey respondents after using the Forestry Assistance/Incentive and Educational Programs designed for forest landowners, West Virginia, $2005(n=30)$. 


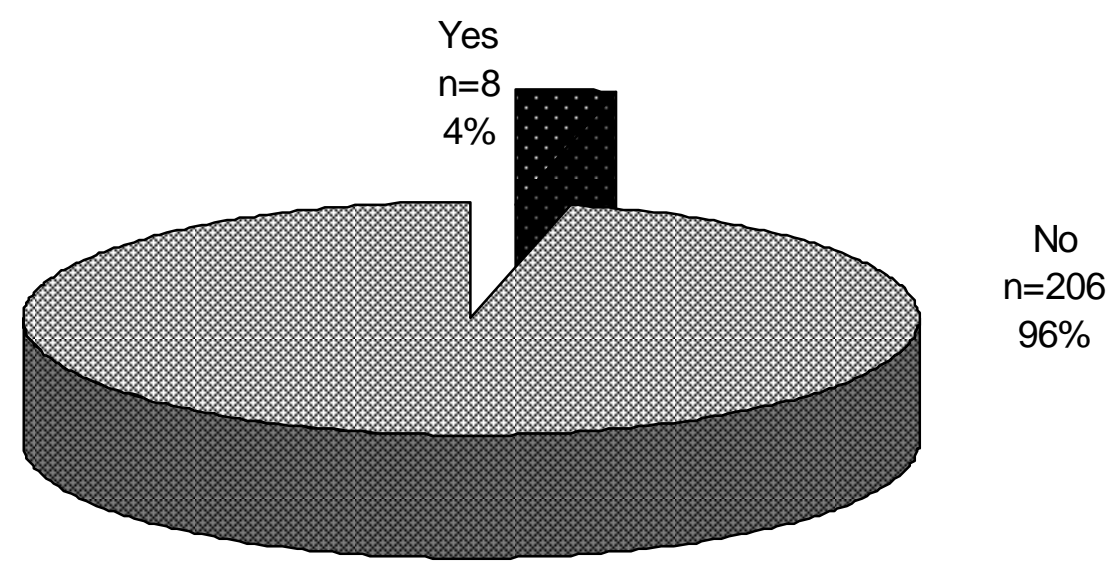

Figure 3. 34: Attendance of NIPF survey respondents to educational programs designed for forest landowners, West Virginia, $2005(n=214)$.

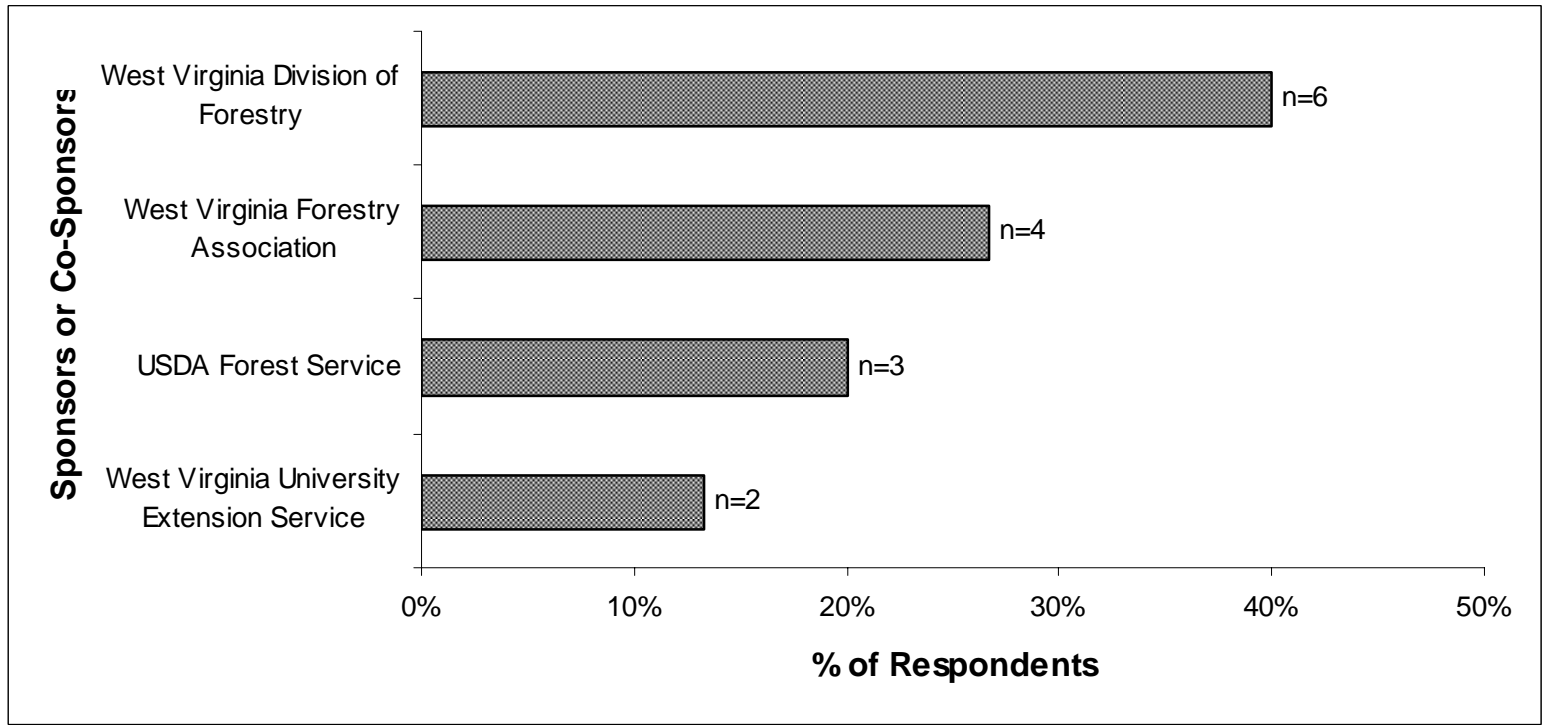

Note: Sum of the responses exceed the no. of responses since respondents chose more than one option. Figure 3. 35: Distribution of the different sponsors or co-sponsors of educational programs attended by the NIPF survey respondents, West Virginia, $2005(n=8)$. 


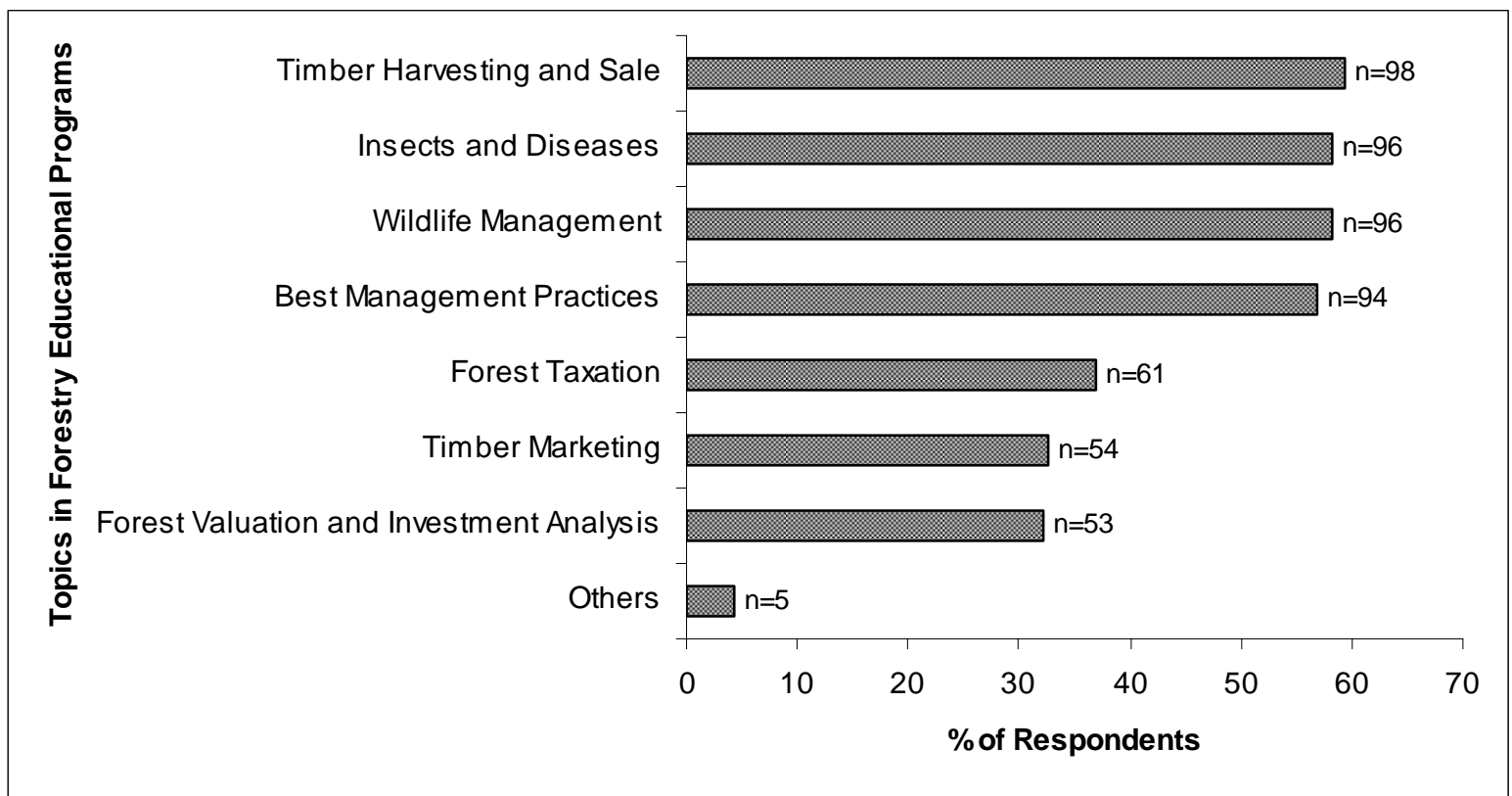

Note: Sum of the responses exceed the no. of responses since respondents chose more than one option. Figure 3. 36: Preferred topics for educational programs by NIPF survey respondents, West Virginia, 2005 ( $n=168)$.

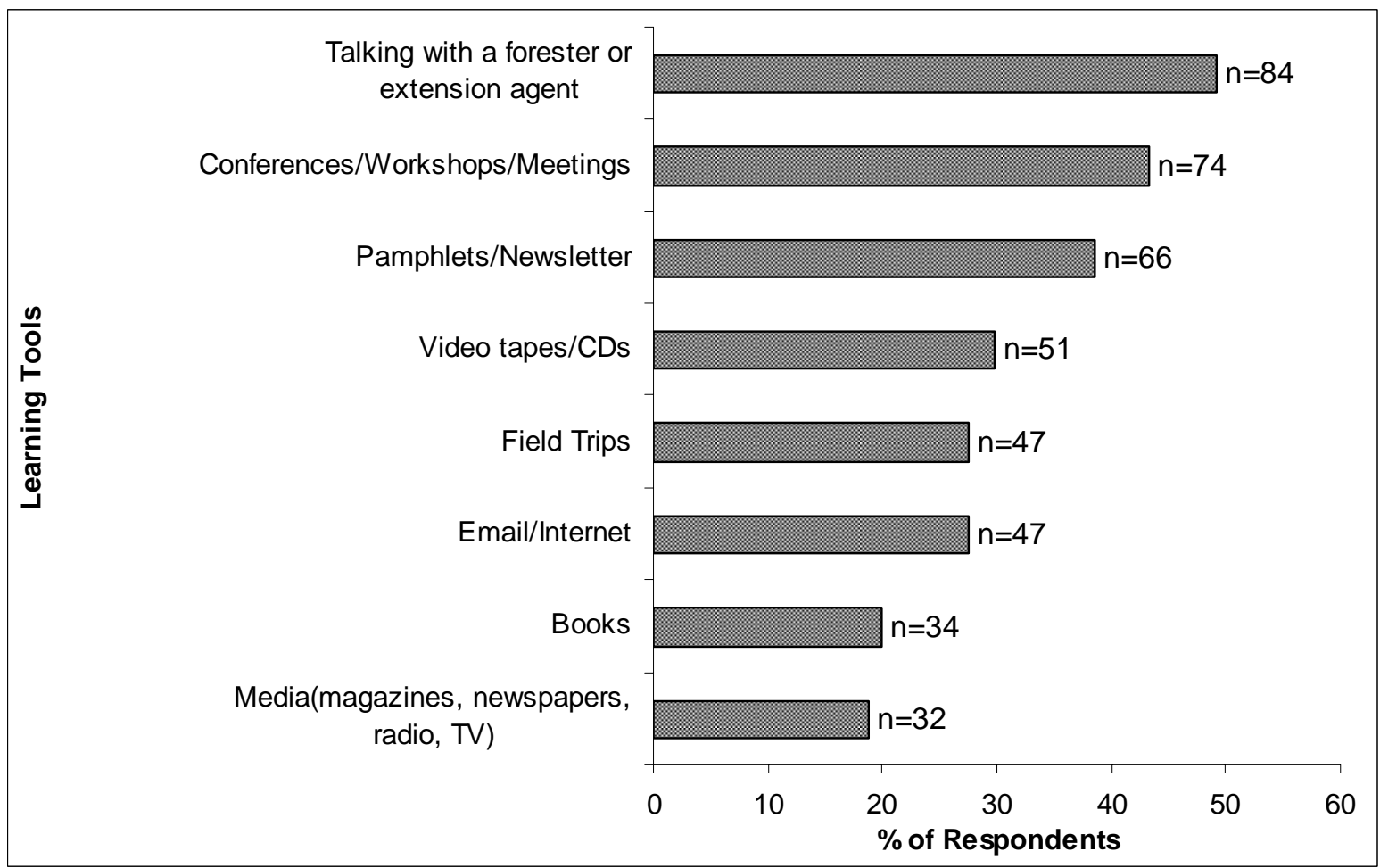

Note: Sum of the responses exceed the no. of responses since respondents chose more than one option. Figure 3. 37: Preferred learning tools by NIPF survey respondents for effective delivery of the forestry educational materials, West Virginia, $2005(n=172)$. 


\subsubsection{Demographics}

The last part of the survey asked demographic questions to the NIPF landowners.

Only 6\% of the respondents were members of forestry-related organizations (Figure 3.38).

The average age of the respondents was 59 (Figure 3.39) and majority (81\%) of the

respondents was male (Figure 3.40) and Caucasian (94\%) (Figure 3.41).

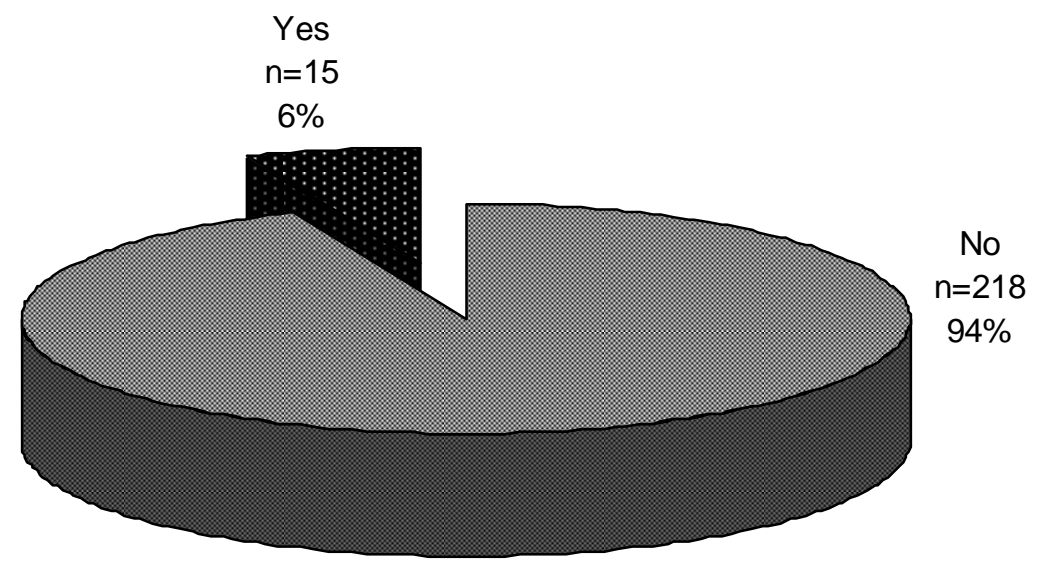

Figure 3. 38: Distribution of NIPF survey respondents by whether they have membership to forest-related organizations, West Virginia, $2005(\mathrm{n}=233)$.

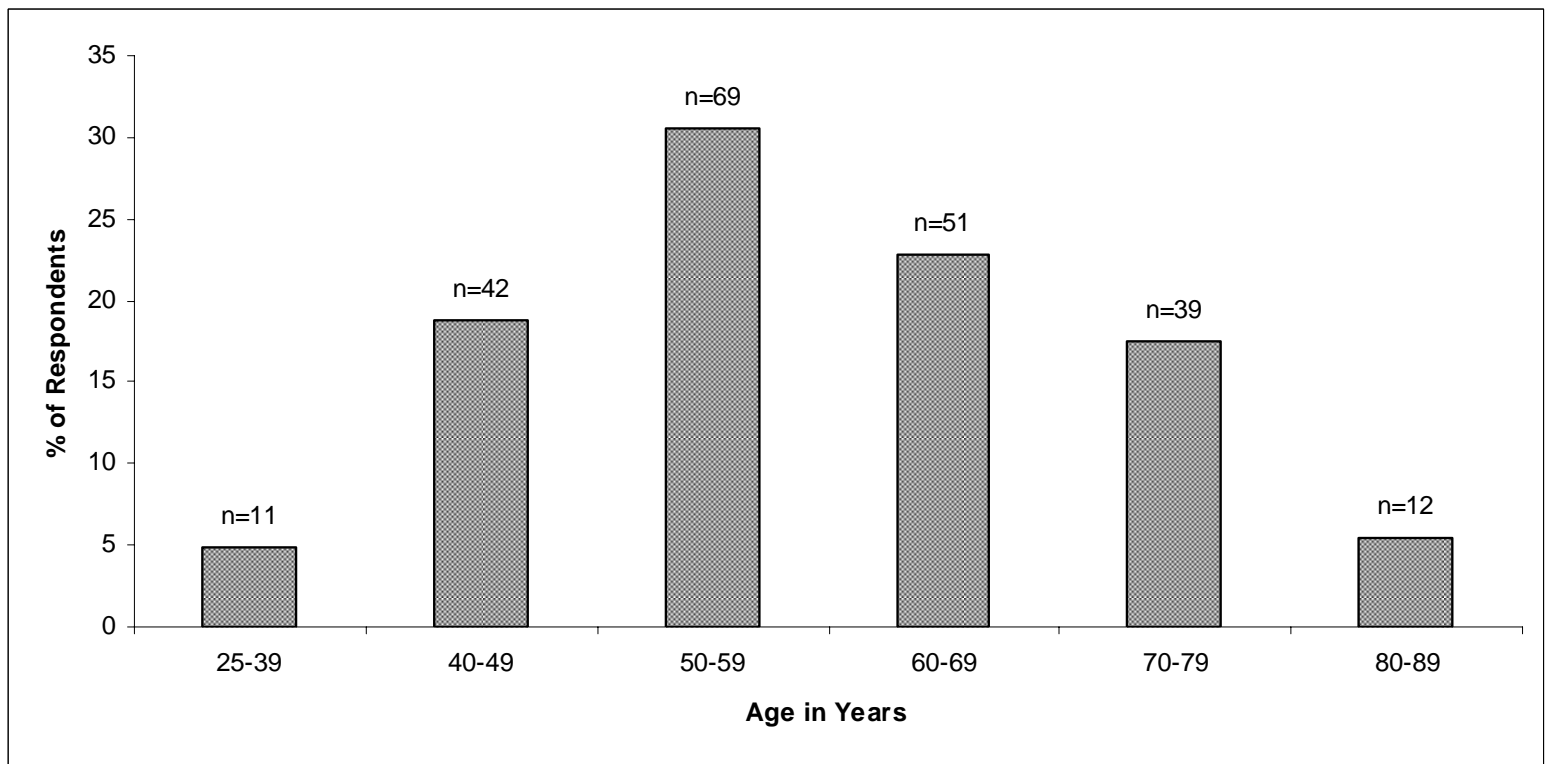

Figure 3. 39: Distribution of NIPF survey respondents by age, West Virginia, $2005(\mathrm{n}=224)$. 


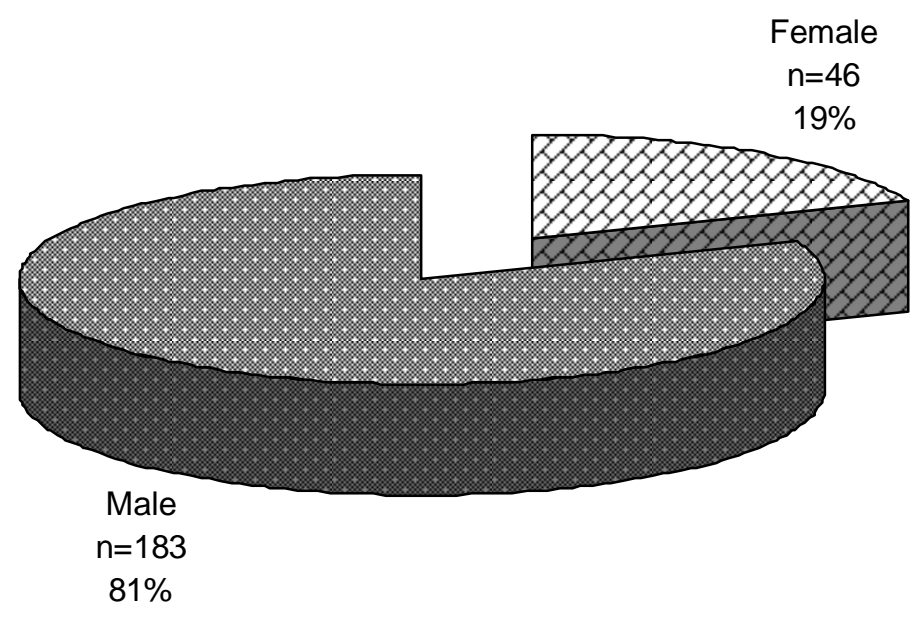

Figure 3. 40: Distribution of NIPF survey respondents by gender, West Virginia, 2005 $(n=229)$.

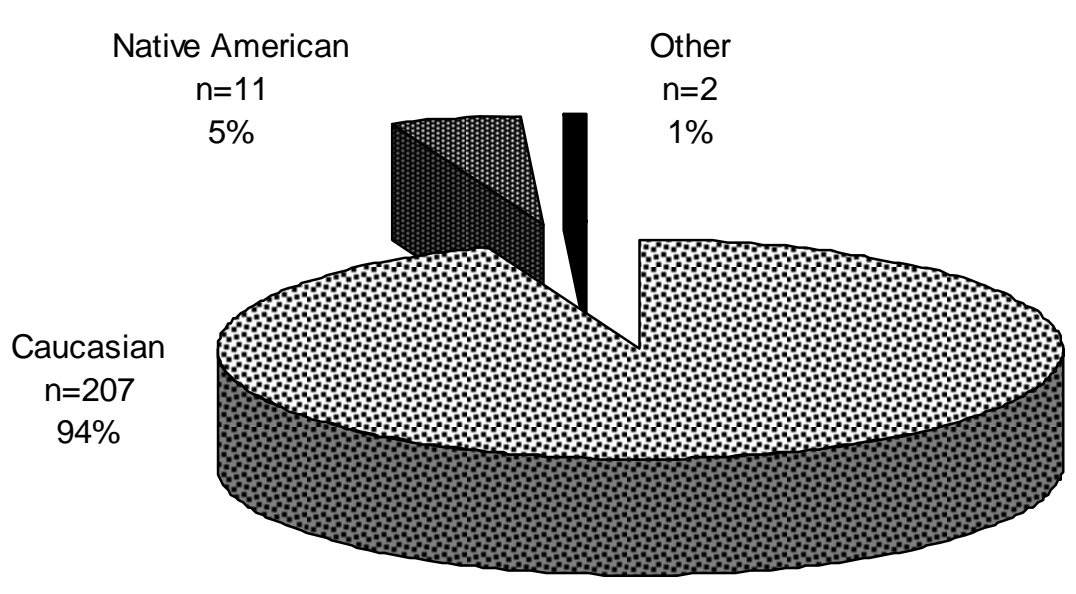

Figure 3. 41: Distribution of NIPF survey respondents by race, West Virginia, 2005 (n=220).

Most of the respondents were high school graduates and above (Figure 3.42). Most of the respondents were professionals or retired (Figure 3.43). Most (47\%) of the respondents earned between $\$ 20,000$ and $\$ 60,000$, while almost a quarter of the respondents were from the higher income group with an annual household income of more than $\$ 100,000$ (Figure 3.44). 


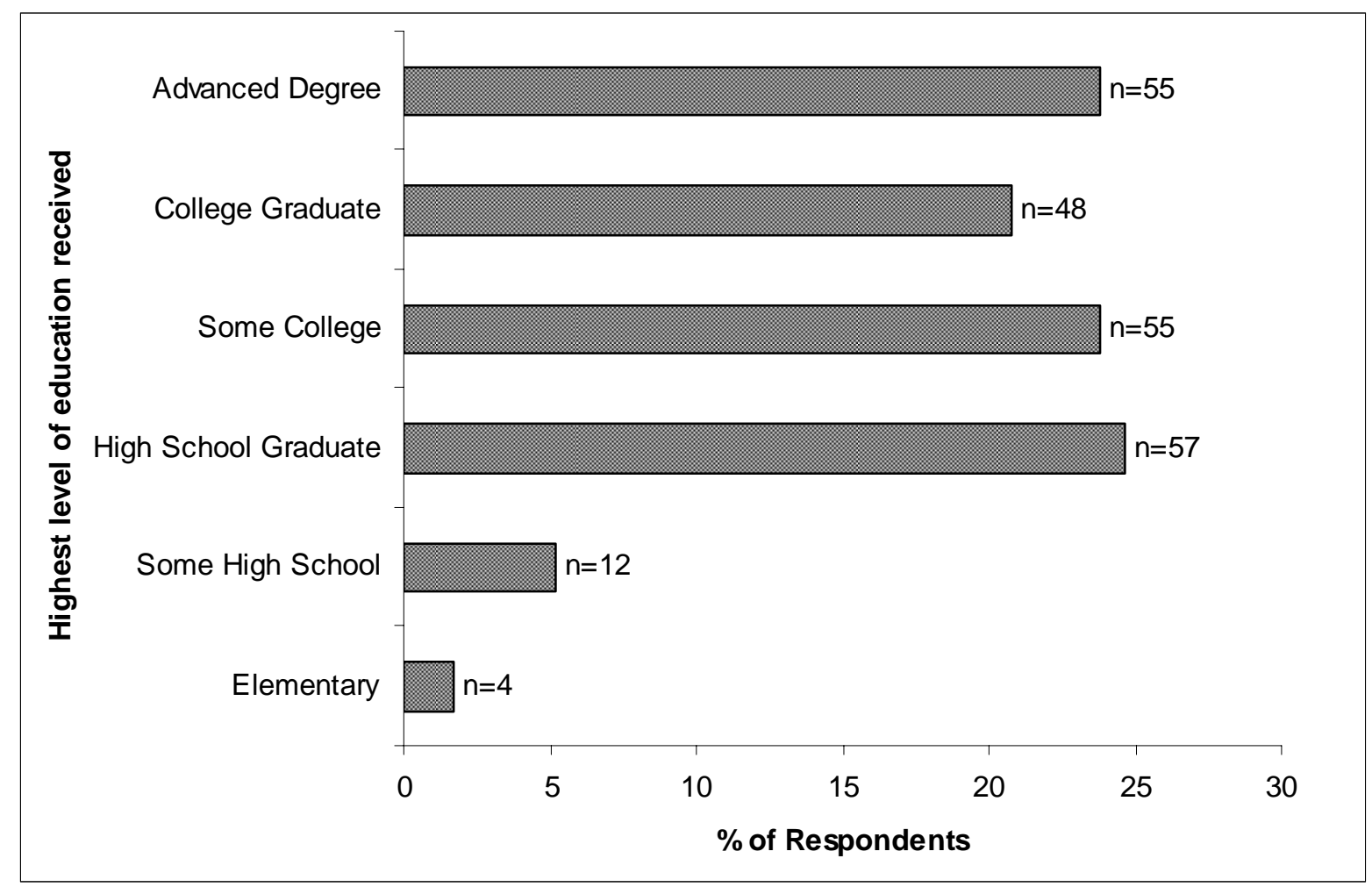

Figure 3. 42: Distribution of NIPF survey respondents by education level, West Virginia ( $n=231), 2005$.

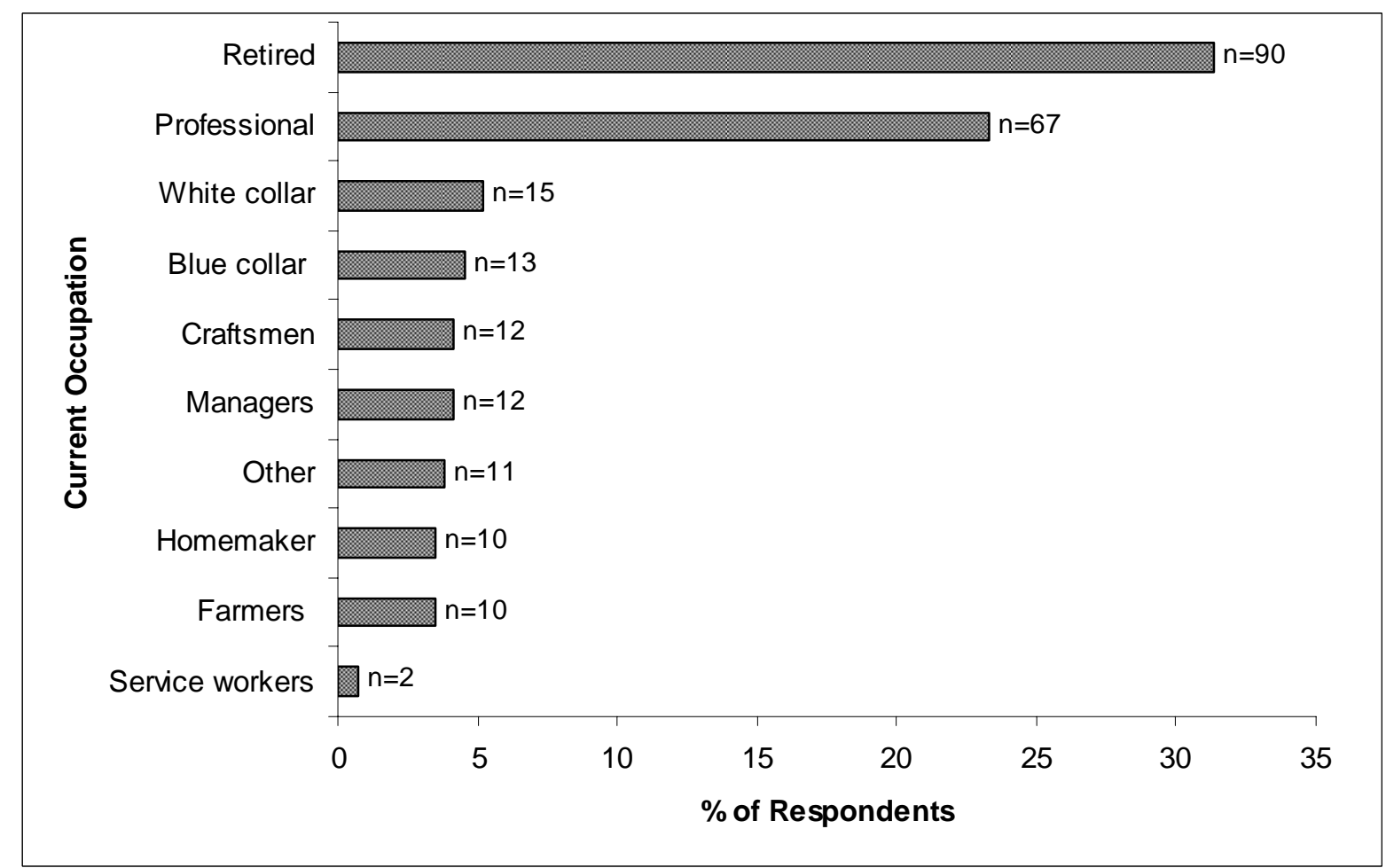

Figure 3. 43: Distribution of NIPF survey respondents by occupation, West Virginia, 2005 $(n=242)$. 


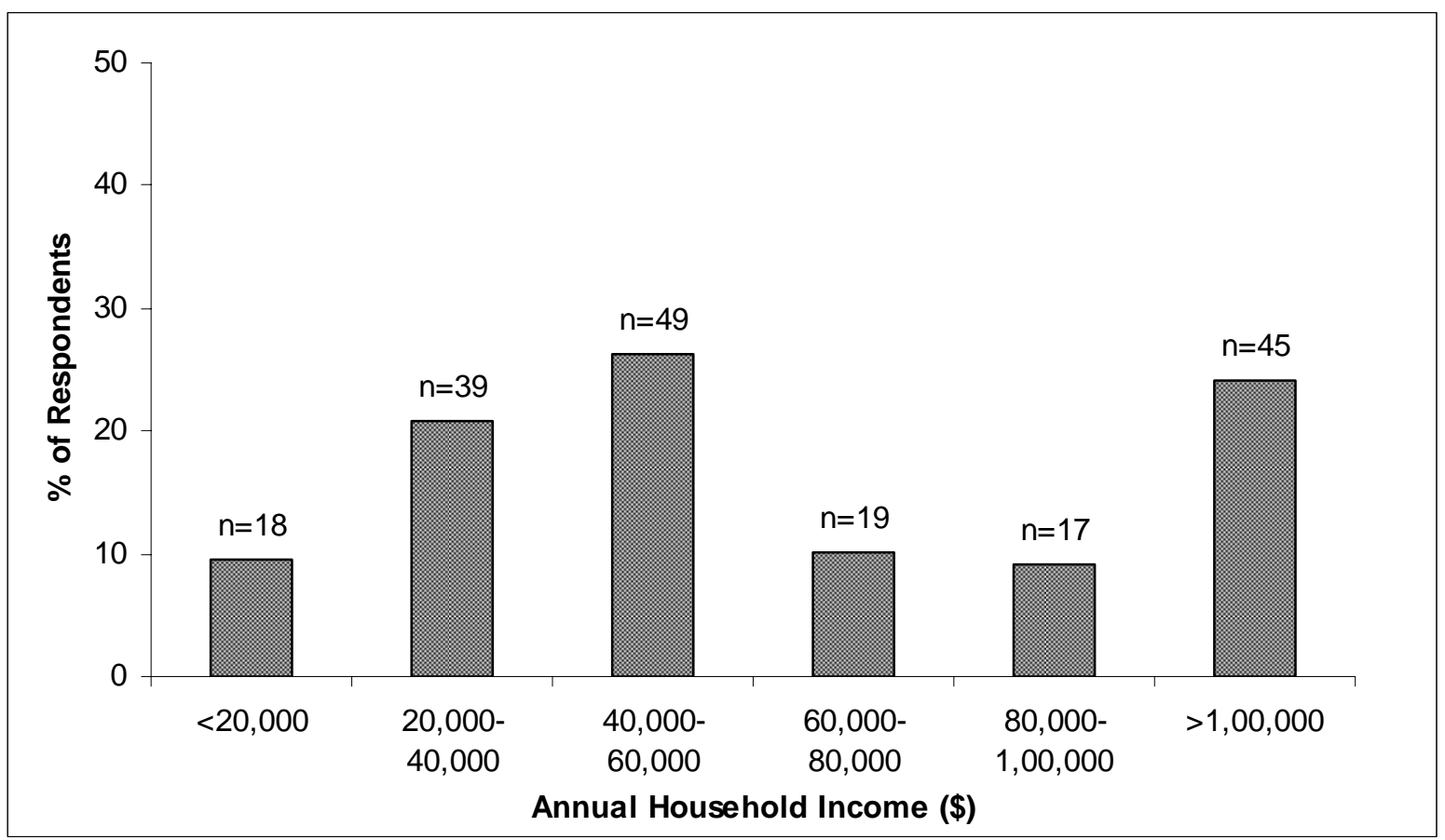

Figure 3. 44: Distribution of NIPF survey respondents by annual household income, West Virginia, 2005 ( $n=187)$.

\subsection{Discussion}

This study presents the findings of a forest landowner survey carried out in the fall of 2005. The findings of the survey are important in providing a better understanding of the state’s NIPF landowner characteristics and their forest management decisions. West Virginia NIPF landowners are similar in many aspects to their counterparts in other regions of the country.

The results of the survey showed that NIPF respondents consisted mainly of the small forest landholders with a median forestland ownership of 43 acres. Hardwood forest dominated the respondents' forest landholdings with more than $83 \%$ of the total forestland owned in hardwood forest. Thus, landowners in West Virginia have the potential to be an important source of hardwood resources not only for the state but for the nation as a whole. 
Landowners in West Virginia own their forestland mainly for non-timber benefits (i.e., aesthetics, residence, recreation, wildlife, land investment, and water quality) rather than for timber production. This is not surprising as previous studies have also shown that NIPF landowners are placing greater emphasis on non-timber benefits over timber benefits of forest ownership (e.g., Haymond 1988, Birch 1994, Rickenbach et al. 1998, Erickson et al. 2002, Belin 2005). However landowners who thought timber as one of the most important reasons for owning their forestland owned $97 \%$ of the total forestland that was reported by the respondents indicating that landowners with larger forestlands are still interested in harvesting timber.

The results also suggest that most landowners are not actively managing their forestland. Less than $13 \%$ of the respondents have conducted any type of forest management activity. This behavior is also true for landowners in other regions. For example, Arano and Munn (2006) also reported that NIPF landowners in Mississippi are not managing intensively. Even earlier studies on NIPF landowners have indicated how these landowners often managed less intensively (e.g., Adams et al. 1992, Kurtz et al. 1993, Alig and Adams 1995). This behavior can be partly attributed to the small holdings owned by many of the landowners in the state.

Approximately 97\% of the respondents have forest holdings that are 100 acres or less. Landowners with smaller holdings tend to have limited management options (Conner and Hartsell 2002) and managing smaller holdings may not be viewed as a practical undertaking (Wicker 2002). Majority of the respondents managed their forestland on their own. Few respondents have sought the help of professional foresters. However, the respondents who sought the help of professional foresters owned $97 \%$ of the total forestland owned by 
respondents. In addition, only $12 \%$ of the respondents had written management plan. This is typical of private forest landowners in the Northern United States (e.g., Birch 1997).

In terms of timber harvestings, only $21 \%$ of the landowners had harvested timber in the past five years. Although some landowners have expressed interest towards a future timber harvest, majority (52\%) of them are still not interested. This lack of interest in timber harvesting coupled with less intensive forest management practices may have a critical impact on the overall hardwood supply in the state.

In order to encourage landowners to be more actively involved in managing their forestlands, the state offers several forestry assistance/incentive and educational programs (e.g., Forest Stewardship Program, Forest Land Enhancement Program). However, the respondents indicated low level of awareness and participation in the various kinds of forestry assistance/incentive and educational programs that were being offered in the state. This does not present a very encouraging scenario as to the effectiveness of these programs in reaching their constituencies and poses a real challenge to come up with more effective programs. This is especially true since almost all the forest management activities conducted by the respondents were found to be associated with their awareness about the various assistance/incentive programs. A number of studies (e.g., Brunson et al. 1996, Bliss et al. 1997, Egan et al. 1997, Rickenbach et al. 1998, Belin et al. 2005) have suggested the need for a broader type of assistance package covering broad array of topics for forest management not just timber management in order to increase the interest of the NIPF landowners in attending the various forestry assistance/incentive and educational programs. Given that these landowners are not just interested in producing timber, such type of assistance package may attract more landowners. 
In terms of demographic characteristics, West Virginia NIPF respondents also mirror their counterparts in other regions of the country. For example, majority of the NIPF respondents are male, Caucasian, of older age, highly educated, relatively well-off, and most live on or near their property. Such characteristics are similar in many aspects to those reported in other studies (e.g., Birch 1996, Rickenbach et al. 1998, Belin et al. 2005).

This study presents information on West Virginia's landowner characteristics and management intentions. Such information is needed because effective private forestry programs rely on published behavior of these owners and descriptions of the conditions of their forest properties. However, further analysis on the relationship between their characteristics and their management decisions are needed to better understand them and their decision pattern. 


\section{CHAPTER IV: FOREST MANAGEMENT DECISIONS OF NON- INDUSTRIAL PRIVATE FOREST LANDOWNERS OF WEST VIRGINIA}

\subsection{Introduction}

Nonindustrial private forest landowners own the majority of the forestlands in West Virginia and so their forest management decisions may have important implications to timber availability in the state. More than 260,000 NIPF landowners own 9,701,000 acres of the 12 million acres of forestland in the state (USDA Forest Service 2007) and the number of NIPF

landowners continue to increase. Since the policy decisions at the state and federal level have resulted in limiting the harvests from public forestlands, the US future timber supply rests largely on private lands (Haynes 2002).

Forestry investment can be defined as any expenditure of time or money in forest management activities (Romm et al. 1987), which may include timber harvest, tree planting, thinning, herbicide application, road construction or maintenance, access control, survey and boundary maintenance, weed control, timber stand improvement, wildlife habitat management, and recreation improvement. One of the important aspects of private timber supply behavior is the investments these private landowners will make in forest management. Investment behavior of private owners has a major impact on anticipated long-term price and consumption behavior in forest products markets (Adams et al. 2001). Thus, the long-term timber supply prospects depend on the forest investment (Alig et al. 2003) of these private forest landowners.

In understanding the role of the NIPF landowners in US timber supply, many studies have been carried out to look at various aspects of NIPF landowners' forest management behavior. One branch of study has looked at linking NIPF landowner characteristics with 
their forest management decisions (e.g., Greene \& Blatner 1986, Romm et al. 1987, Kuuluvainen et al. 1996, Conway et al. 2003, and Elwood et al. 2003). These studies have shown that various landowner and ownership characteristics are significant determinants of the forest management behavior of the NIPF landowners. Similarly, objectives for owning the forestland and attitudes of the landowners have also been found to affect their management decisions (e.g., Tornqvist 1995, Kuuluvainen et al. 1996, Nagubandi et al. 1996, Karppinen 1998, Conway et al. 2003, Finley \& Kittredge 2006).

Even though NIPF landowners have been extensively studied, composition of the NIPF landowners continue to change (Haynes 2002), so there is a need of continually readdressing the issues related to these private landowners. This study examines whether NIPF landowners of West Virginia can be characterized based on their owner, ownership and management characteristics.

\subsection{Theoretical Model}

As noted by Amacher et al. (2003), there has been a shift in the theory describing NIPF landowners as utility-maximizers rather than profit-maximizers. The decision to invest in forest management activities depends on the landowners' utility maximizing behavior. Utility is modeled as a random variable to reflect the uncertainty in the landowners' decisionmaking pertaining to incomplete information (Manski 1977). The model used in this study assumes that the landowners maximize their utility from consumption of timber and nontimber outputs as a result of investment in their forestlands. This utility derived by landowners is an unobservable utility index determined by a set of observable factors (Bell et al. 1994, Mills et al, 1996, Nagubandi et al. 1996). Decision to invest in the forestland by engaging in forest management activities can however be explained by a set of observable 
factors. Previous studies have shown that NIPF landowner and ownership characteristics were associated with the landowners’ forest management decisions (e.g., Greene \& Blatner 1986, Romm et al. 1987, Bliss \& Martin 1989, Nagubandi et al. 1996, Erickson et al. 2002, Elwood et al. 2003). Similarly, objectives for owning the forestland and landowner attitudes have also been found to affect landowner decisions (e.g., Tornqvist 1995, Kuuluvainen et al. 1996, Nagubandi et al. 1996, Karppinen 1998, Conway et al. 2003, Finley \& Kittredge 2006).

The decision factors to engage in forest management activities are assumed to be a vector of landowner characteristics (e.g., age, education, income), ownership characteristics (e.g., forest size, year of acquisition, mode of acquisition, distance of the forest parcel from the place of residence) and management characteristics (primary objective for owning the forestland, who manages the forest property, presence of a written forest management plan). Thus, the utility model for the landowner forest investment behavior can be presented as: $U_{i}=f\left\{T N(I N V) \mid O_{i}, L_{i}, M_{i}\right\}$

where, $\mathrm{U}_{\mathrm{i}}$ represents utility derived by the $\mathrm{i}^{\text {th }}$ landowner by investing in forest management activities; TN represents a production function for timber and nontimber outputs which are consumed by forest landowners; and INV represents investments made in the forestland by the landowner in order to consume the timber and notimber outputs. Forestland outputs and therefore investments are assumed to be conditional on three sets of characteristics: $\mathrm{O}_{\mathrm{i}}$ (owner characteristics); $\mathrm{L}_{\mathrm{i}}$ (forest land ownership characteristics); and $\mathrm{M}_{\mathrm{i}}$ (management characteristics).

The econometric model used in the study in order to interpret the decision to invest in forest management activities represents an indirect measure of utility: 
$I N V=f\left(O_{i}, L_{i}, M_{i}\right)+\varepsilon_{i}$

where, $\varepsilon_{\mathrm{i}}$ is the random error term.

\subsection{Methodology}

\subsubsection{Data}

The data used for this study came from a mail survey conducted in 2005 to the NIPF landowners of West Virginia. The survey collected information regarding the forest management activities conducted by landowners in 2004 and prior to 2004. A total of thirteen forest management activities had been presented to the landowners viz. timber harvesting, tree planting, herbicide application, fertilization, thinning, road construction, road maintenance, surveying/boundary maintenance, access control, grapevine control, timber stand improvement, wildlife habitat improvement and recreation improvement. Since less than $13 \%$ of the respondents had carried out any type of forest management activities in 2004, the 13 activities that were conducted in 2004 and prior to 2004 were combined and were categorized into four groups: i) harvest was considered as a separate activity, HARVEST; ii) six of the activities were lumped into one category as silvicultural activities (i.e., tree planting, herbicide application, fertilization, thinning, grapevine control, timber stand improvement), SILVICULTURE, iii) four activities were categorized as property management activities (road construction, road maintenance, surveying/boundary maintenance, access control) PROPERTY, and iv) two activities: wildlife habitat improvement and recreation improvement were combined into a separate category, RECREATION. Therefore, the study looked at the decision of the landowners to engage in these four distinct categories. 


\subsubsection{Empirical Model and Definition of the Variables}

A landowner makes decisions regarding the management of the forest in a way that maximizes his or her utility derived from the forest. This study looked at four categories of decisions regarding the forest management of NIPF landowners or four dependent variables: HARVEST, SILVICULTURE, PROPERTY, and RECREATION. Each of the dependent variables had two responses, " 1 ” if a landowner had engaged in at least one of the activities in the given category and " 0 " if the landowner had not engaged in any of the activities in the given category. Thus, the empirical models are expressed as:

HARVEST $=\beta_{0}+\beta_{1} A G E+\beta_{2} E D U C+\beta_{3} P R O F+\beta_{4} I N C O M E+\beta_{5} L N F O R A C+\beta_{6} Y R A C Q$ $+\beta_{7}$ DISTMILE $+\beta_{8}$ PURCHASE $+\beta_{9}$ TIMBER $+\beta_{10} N O N T I M+\beta_{11} L A N D I N V$

$+\beta_{12}$ FORESTER $+\beta_{13}$ FRMP $+\varepsilon$

SILVICULTURE $=\beta_{0}+\beta_{1} A G E+\beta_{2} E D U C+\beta_{3} P R O F+\beta_{4} I N C O M E+\beta_{5} L N F O R A C$ $+\beta_{6}$ YRACQ $+\beta_{7}$ DISTMILE $+\beta_{8}$ PURCHASE $+\beta_{9}$ TIMBER $+\beta_{10}$ NONTIM $+\beta_{11} L A N D I N V+\beta_{12}$ FORESTER $+\beta_{13}$ FRMP $+\varepsilon$

PROPERTY $=\beta_{0}+\beta_{1} A G E+\beta_{2} E D U C+\beta_{3} P R O F+\beta_{4} I N C O M E+\beta_{5} L N F O R A C+\beta_{6} Y R A C Q$ $+\beta_{7}$ DISTMILE $+\beta_{8}$ PURCHASE $+\beta_{9}$ TIMBER $+\beta_{10} N O N T I M+\beta_{11} L A N D I N V$ $+\beta_{12}$ FORESTER $+\beta_{13}$ FRMP $+\varepsilon$

RECREATION $=\beta_{0}+\beta_{1} A G E+\beta_{2}$ EDUC $+\beta_{3}$ PROF $+\beta_{4}$ INCOME $+\beta_{5} L N F O R A C$ $+\beta_{6}$ YRACQ $+\beta_{7}$ DISTMILE $+\beta_{8}$ PURCHASE $+\beta_{9}$ TIMBER $+\beta_{10}$ NONTIM $+\beta_{11} L A N D I N V+\beta_{12}$ FORESTER $+\beta_{13}$ FRMP $+\varepsilon$

where $\beta$ s and $\varepsilon$ are the model coefficients and the error term, respectively. The description of the independent variables is listed in Table 4.1. The independent variables were tested for multicollinearity problems and none of the variables had a correlation coefficient above 0.5 except for the correlation between age, AGE and forestland acquisition period, YRACQ 
(Appendix B). Also, the Variance Inflation Factor ${ }^{*}$ (VIF) was calculated for the independent variables to test for possible multicollinearity. None of the independent variables had VIF values above 2 which meant that the independent variables were free from multicollinearity problem.

Table 4. 1: Description of the independent variables in the empirical models that examine the factors affecting landowners' decision to engage in forest management activities, West Virginia.

\begin{tabular}{|c|c|}
\hline Variables & Definition \\
\hline \multicolumn{2}{|c|}{ Owner Characteristics } \\
\hline AGE & Age of the respondents in years \\
\hline EDUC & Education level of the respondents. $1=$ college graduate/above, $0=$ Others \\
\hline PROF & Current occupation. 1= Professional/Manager/White Collar, 0= Others \\
\hline INCOME & Annual Household income of the respondents. Ordinal variable with \\
\hline & $\begin{array}{l}\text { values } 1-6 . \\
1=<\$ 20.000\end{array}$ \\
\hline & $2=\$ 20,000-\$ 40,000$ \\
\hline & $3=\$ 40,000-\$ 60,000$ \\
\hline & $4=\$ 60,000-\$ 80,000$ \\
\hline & $5=\$ 80,000-\$ 100,000$ \\
\hline & $6=>\$ 100,000$ \\
\hline \multicolumn{2}{|c|}{ Ownership Characteristics } \\
\hline LNFORACRE & Natural log of forest acreage \\
\hline YRACQ & No. of years since acquiring the first parcel of forest \\
\hline DISTMILE & Distance of the nearest forest land from the place of residence in miles \\
\hline PURCHASE & How the property was acquired. $1=$ Purchased, $0=$ Inherited or gift \\
\hline \multicolumn{2}{|c|}{ Management Characteristics } \\
\hline TIMBER & $\begin{array}{l}\text { Timber as primary objective. } \\
1=\text { very important to } 4=\text { not important at all }\end{array}$ \\
\hline NONTIM & $\begin{array}{l}\text { Non-timber activities (i.e., Recreation, Hunting, Aesthetics, Water Quality } \\
\text { and Non timber Forest Products) as primary objective. } \\
1=\text { very important to } 20=\text { not important at all }\end{array}$ \\
\hline LANDINV & Land investment as primary objective. \\
\hline FORESTER & Professional forester manages the property. $1=$ professional forester, \\
\hline FRMP & Has a written forest management plan. $1=$ Yes and $0=\mathrm{No}$ \\
\hline
\end{tabular}

\footnotetext{
${ }^{*}$ VIF is a multicollinearity diagnostic statistics produced by linear regression analysis. Values of VIF above 2.5 may be a cause for concern in logistic regression (Allison 1999)
} 


\section{Owner characteristics}

A total of four variables representing the owner characteristics were used in the models: age, education, occupation, and annual household income. Romm et al. (1987) reported a negative relationship between the old age (>64 years) and forestry investment. Similarly, Kuuluvainen and Salo (1991) in their study had found that harvest rates tend to decrease with age because of credit rationing. Age (AGE) is thus hypothesized to be negatively related to landowners' participation in all the four dependant variables. Education (EDUC) on the other hand is expected to have a positive association with all four dependant variables since landowners with higher education are expected to be better informed of the pros and cons of investment alternatives to better understand the benefits associated with forest management. Various studies have found higher education to favor forest activity (e.g., Straka and Doolittle 1987, Bell et al. 1994, Nagubandi et al. 1996). Landowners who are professionals, managers or white collar are thought to be well-educated and financially strong and, thus, motivated towards forest investment. Thus landowners who are professionals, managers or white collar are also expected to have a positive association with all four dependant variables. Similarly higher income (INCOME) is also expected to be associated with higher probabilities of engagement in the forest management activities. Income level increases the easy access to resources such as larger tract size, information, private consultants, etc. Previous literatures have found income to be positively associated with forest activity (DeSteiguer 1982, Romm et al. 1987, Straka and Doolittle 1988). 


\section{Ownership characteristics}

Four variables representing the ownership characteristics were used in the models. Size of the forestland ownership (LNFORACRE) has been found to be one the strongest determinants of active forest management. The coefficient on landownership size have been found to be positive in the harvesting probability models (e.g., Binkley 1981, Hyberg and Holthausen 1989, Conway 1998), in reforestation probability models (e.g., Cohen 1983, Straka and Doolittle 1987, Hardie and Parks 1996), and also in forestry program participation (e.g., Nagubandi et al. 1996). Forestland ownership size is thus hypothesized to be positively associated with the all four dependant variables. Year of forestland acquisition (YRACQ) is also hypothesized to be positively related to all four dependant variables since longer period of ownership may indicate their interest towards the forestland and thus subsequent activities in the forestland to meet their goal for owning the forestland. Absentee ownership has been found to reduce the probability of landowners engaging in forest management activities (e.g., Romm et al. 1987) so the variable representing the distance of the nearest forest parcel from the landowner's place of residence (DISTMILE) is expected to be negatively associated with all four dependant variables. Landowners who purchased (PURCHASE) their forestland are expected to have acquired the forestland with a specific interest towards the use of the forestland and subsequently be more concerned about the management of the forestland than the landowners who received their forest properties through inheritance or as gift. Thus, landowners who purchased their forestland are expected to have a higher probability to be engaged in all four categories forest management activities. 


\section{Management characteristics}

Five variables representing the management characteristics were also included in the models. Forest landowners' objectives for owning the forestland are expected to affect their management decisions. Kuuluvainen et al. (1996) suggested that attitudes and ownership objectives could be used to forecast major trends in future timber supply because of their role in varying the timber harvest rates. Nagubandi et al. (1996) found that landowners who owned the forestland for land investment or timber, were more likely to participate in forestry assistance programs. If landowners’ primary objective was timber or wood-use related, then it is expected that they would be more likely to harvest timber (HARVEST), undertake silvicultural (SILVICULTURE) and property management (PROPERTY) activities, and also engage in habitat management (RECREATION). Greene and Blatner (1986) found that landowners with recreation, wildlife, and grazing as primary objectives had higher probabilities of undertaking timber management. If the landowners’ primary objective was non-timber related, then it is expected that he or she would more likely engage in timber harvesting (HARVEST), silvicultural activities (SILVICULTURE), property management activities (PROPERTY), and habitat management and recreational improvement (RECREATION). It is also expected that if the landowners’ primary objective was land investment (LANDINV), then they would also more likely engage in all the four categories of forest management activities.

It is also expected that the landowners who sought the help of professional foresters (FORESTER) would have higher probabilities of engaging in forest management activities. Technical assistance has been found to be associated with higher probabilities of forest activity (e.g., Boyd 1984, Hyberg and Holthausen 1989). Also Nagubandi et al. 1996 found 
that landowners who thought of professionals as important source of information for managing their forestland were more likely to participate in the forestry assistance programs. Written forest management plans (FRMP) are prepared by landowners interested in managing their forestland in realizing their long-term objectives, whether financial or enjoyment related. Baughman et al. (1998) suggested that written forest management plans would encourage landowners in timber harvesting, weed control, build access roads or to carry out other timber stand improvement activities. So, it is expected that landowners with a written forest management plan would be more likely to engage in forest management activities.

\subsubsection{Model Estimation}

Since the dependent variables are dichotomous, Yes/No response variables, logistic regression models were used for estimation of the model parameters. Logistics regression is based on the cumulative logistic probability function and estimates the probability of a certain action given a set of categorical characteristics (Pindyck and Rubinfeld, 1981).

$$
P_{i}=E\left(Y=1 \mid X_{i}\right)=\frac{1}{1+e^{-\left(\alpha+\beta_{i} X_{i}\right)}}
$$

or, $P_{i}=E\left(Y=1 \mid X_{i}\right)=\frac{1}{1+e^{-Z_{i}}}$

where, $Z_{i}=\alpha+\beta_{i} X_{i}$

Thus, in logistic regression the probability of each outcome is expressed as:

$\log \frac{P_{i}}{1-P_{i}}=\alpha+\beta_{i} X_{i}=Z_{i}$

where, 
$P_{i}=$ probability that a landowner invests in a forest management activity

$\beta_{i}=$ model coefficients

$X_{i}=$ independent variables

While logit model is based on the cumulative logistic probability function, another popular model used for predicting the binary outcome dependent variables is the probit model. Probit model is based on the cumulative normal probability function (Pindyck and Rubinfeld, 1981).

$P_{i}=F\left(Z_{i}\right)=\frac{1}{\sqrt{2 \pi}} \int_{-\infty}^{Z_{i}} e^{-t^{2} / 2} d t$

where, $\mathrm{t}$ is a standardized normal variable, i.e., $\mathrm{t} \sim \mathrm{N}(0,1)$.

So,

$Z_{i}=F^{-1}\left(P_{i}\right)=\alpha+\beta_{i} X_{i}$

Since logit and probit are nonlinear binary response models, ordinary least squares is no longer the appropriate method of estimation. Maximum likelihood estimation is used to estimate the models since it automatically accounts for the variance in the dependent variable conditional on independent variables.

Logit and probit formulations are quite comparable and the choice between the two is mostly of convenience and ease of computing (Gujarati, 1995), so the model estimations were carried out using both the methods. However, the results were discussed on the outcomes of the logistic regression models.

SAS software was used to estimate the parameters and marginal effects. Summary statistics of the variables are presented in Table 4.2 
Table 4. 2: Descriptive statistics of the dependent and independent variables used in the models that examine the factors affecting landowners' decision to engage in forest management activities, West Virginia, 2000-2004.

\begin{tabular}{lrrr}
\hline Variable & $\mathbf{N}$ & Mean & Std Dev \\
\hline HARVEST & 240 & 0.28333 & 0.45156 \\
SILVICULTURE & 182 & 0.45604 & 0.49944 \\
PROPERTY & 182 & 0.46703 & 0.50029 \\
RECREATION & 181 & 0.34807 & 0.47768 \\
FRO & 233 & 0.06438 & 0.24595 \\
AGE & 224 & 59.11607 & 12.52531 \\
EDUC & 232 & 0.44397 & 0.49792 \\
PROF & 232 & 0.24138 & 0.42885 \\
INCOME & 187 & 3.60428 & 1.69553 \\
LNFORAC & 206 & 4.00594 & 1.39100 \\
YRACQ & 217 & 20.15668 & 14.97570 \\
DISTMILE & 238 & 76.09164 & 234.97622 \\
PURCHASE & 238 & 0.71429 & 0.45271 \\
TIMBER & 219 & 3.08219 & 1.17411 \\
NONTIM & 226 & 11.71681 & 4.49685 \\
LANDINV & 216 & 2.44907 & 1.19191 \\
FORESTER & 241 & 0.07884 & 0.27005 \\
FRMP & 240 & 0.11667 & 0.32169 \\
\hline
\end{tabular}

\subsection{Results}

The summary of the results of the four logit models are presented in Table 4.3 and the results from the probit models are presented in Appendix C. The number of observations used in each of the estimation models are fewer than the total number of observations because of the missing responses to the key questions asked in the survey, including the questions used in generating the dependant variables.

\section{HARVEST}

Results of the logit model are presented in Table 4.4. Only 122 respondents were used in estimating the model parameters because of the missing responses to some of the questions that were asked in the survey. Majority of the respondents (71\%) had not harvested any timber either in 2004 and/or prior to 2004. 
Table 4. 3: Comparison of the four logit models examining the factors affecting NIPF landowners' decision to engage in four different categories of forest management activities, West Virginia $(\mathrm{n}=244)$.

\begin{tabular}{|c|c|c|c|c|c|c|c|c|}
\hline \multirow[b]{2}{*}{ Variable } & \multicolumn{2}{|r|}{ HARVEST } & \multicolumn{2}{|c|}{ SILVICULTURE } & \multicolumn{2}{|c|}{ PROPERTY } & \multicolumn{2}{|c|}{ RECREATION } \\
\hline & Sign & $\begin{array}{l}\text { Significance } \\
\text { level }\end{array}$ & Sign & $\begin{array}{l}\text { Significance } \\
\text { level }\end{array}$ & Sign & $\begin{array}{l}\text { Significance } \\
\text { level }\end{array}$ & Sign & $\begin{array}{l}\text { Significance } \\
\text { level }\end{array}$ \\
\hline Const & + & ** & + & ** & + & & + & $*$ \\
\hline AGE & - & ** & - & & - & & - & * \\
\hline EDUC & + & *** & + & * & + & & + & \\
\hline PROF & - & ** & - & & + & & - & \\
\hline INCOME & + & & + & * & + & * & + & \\
\hline LNFORAC & - & & - & * & + & & - & \\
\hline YRACQ & + & * & - & & - & ** & + & \\
\hline DISTMILE & - & & - & & - & & - & ** \\
\hline PURCHASE & + & & + & * & + & ** & + & \\
\hline TIMBER & - & *** & - & ** & - & * & - & \\
\hline NONTIM & - & & - & *** & - & ** & - & *** \\
\hline LANDINV & + & & + & & - & ** & + & \\
\hline FORESTER & + & & - & & + & & + & \\
\hline FRMP & + & * & + & * & + & & - & \\
\hline Likelihood Ratio & & $34.6775^{\star \star \star}$ & & $29.0511^{\star \star \star}$ & & $39.1499 * \star \star$ & & $28.9414^{\star \star \star}$ \\
\hline Chi-square value & & 0.0009 & & 0.0064 & & 0.0002 & & 0.0067 \\
\hline Obs correctly predicted & & $101(83 \%)$ & & 79(77.4\%) & & $84(83 \%)$ & & $80(79 \%)$ \\
\hline Total no of observations & & 122 & & 102 & & 102 & & 102 \\
\hline 1 & & 35 & & 54 & & 53 & & 42 \\
\hline 0 & & 87 & & 48 & & 49 & & 60 \\
\hline
\end{tabular}

* Significant at 10\% level, ** Significant at $5 \%$ level, *** Significant at $1 \%$ level

The model fit was significant at $1 \%$ level. The model correctly predicted $83 \%$ of the observations (101 out of 122). Three variables representing the owner characteristics (AGE, EDUC, and PROF), one variable representing ownership characteristics (YRACQ), and two variables representing management characteristics (TIMBER and FRMP) were significant.

Size of forestland ownership (LNFORAC) was not significantly related to timber harvesting. Age was inversely related to landowners' decision to harvest. This means that younger landowners were more likely to harvest timber. The marginal effect also indicated that holding all the variables constant, one year increase in age of the landowner is going to decrease the probability of harvesting timber by $1.03 \%$. Landowners who were at least college graduates were more likely to harvest timber and their probability of harvesting was 
27.93\% higher than the landowners who were not college graduates. Landowners who were professionals, managers or white collars were found to be less likely to harvest timber, contrary to what was expected. Landowners who were professionals, managers or white collars were found to be $24.62 \%$ less likely to harvest timber than the landowners in other professions. Longer period of forestland acquisition also attributed positively to the probability of harvesting. Landowners who had acquired the forestland for an additional one year had a $0.66 \%$ higher probability to harvest. When the objective of landowners for owning the forestland was timber related, they were also more likely to harvest timber. Also, landowners with written forest management plans were $27.55 \%$ more likely to harvest timber than those who did not have written forest management plant.

Table 4. 4: Parameter estimates of the logit model that examines the factors affecting NIPF landowners' decision to engage in timber harvesting activities, West Virginia.

\begin{tabular}{|c|c|c|c|c|}
\hline Variable & Estimate & & Std Error & Marginal Effect \\
\hline Const & 4.3741 & ** & 2.2962 & \\
\hline AGE & -0.0585 & ** & 0.0288 & -0.0103 \\
\hline EDUC & 1.5806 & $\star \star \star ~$ & 0.6013 & 0.2793 \\
\hline PROF & -1.3937 & $\star \star$ & 0.7180 & -0.2462 \\
\hline INCOME & 0.1256 & & 0.1893 & 0.0222 \\
\hline LNFORAC & -0.2639 & & 0.2148 & -0.0466 \\
\hline YRACQ & 0.0372 & * & 0.0212 & 0.0066 \\
\hline DISTMILE & -0.0020 & & 0.0017 & -0.0004 \\
\hline PURCHASE & 0.0540 & & 0.5612 & 0.0095 \\
\hline TIMBER & -0.6460 & $\star \star \star$ & 0.2375 & -0.1141 \\
\hline NONTIM & -0.0574 & & 0.0644 & -0.0101 \\
\hline LANDINV & 0.0492 & & 0.2021 & 0.0087 \\
\hline FORESTER & 0.2472 & & 0.9892 & 0.0437 \\
\hline FRMP & 1.5595 & * & 0.9155 & 0.2755 \\
\hline Likelihood Ratio & $34.6775^{\star \star \star}$ & & & \\
\hline Chi-square value & 0.0009 & & & \\
\hline Obs correctly predicted & $101(83 \%)$ & & & \\
\hline Total no of observations & 122 & & & \\
\hline & 35 & & & \\
\hline & 87 & & & \\
\hline
\end{tabular}

* Significant at $10 \%$ level, ${ }^{* *}$ Significant at $5 \%$ level, *** Significant at $1 \%$ level 


\section{SILVICULTURE}

Results of the logit model are presented in Table 4.5. Only 102 respondents were used in estimating the model parameters. Majority of the respondents (53\%) had been engaged in some type of silvicultural activity (tree planting, herbicide application, fertilization, thinning, grapevine control, and timber stand improvement) either in 2004 and/or prior to 2004.

The model fit was significant at $1 \%$ level. The model correctly predicted $77.4 \%$ of the observations (79 out of 102). Two variables representing the owner characteristics (EDUC and INCOME), two variables representing ownership characteristics (LNFORAC and PURCHASE), and three variables representing management characteristics (TIMBER, NONTIM, and FRMP) were significant.

Table 4. 5: Parameter estimates of the logit model that examines the factors affecting landowners' decision to engage in silvicultural activities, West Virginia.

\begin{tabular}{|c|c|c|c|c|}
\hline Variable & Estimate & & Std Error & Marginal Effect \\
\hline Const & 5.4430 & ** & 2.3511 & \\
\hline AGE & -0.0341 & & 0.0280 & -0.0085 \\
\hline EDUC & 0.9697 & * & 0.5546 & 0.2410 \\
\hline PROF & -0.8339 & & 0.6460 & -0.2073 \\
\hline INCOME & 0.3096 & * & 0.1802 & 0.0769 \\
\hline LNFORAC & -0.4186 & * & 0.2234 & -0.1040 \\
\hline YRACQ & -0.0018 & & 0.0218 & -0.0005 \\
\hline DISTMILE & -0.0004 & & 0.0009 & -0.0001 \\
\hline PURCHASE & 0.9522 & * & 0.5687 & 0.2367 \\
\hline TIMBER & -0.5029 & $\star *$ & 0.2484 & -0.1250 \\
\hline NONTIM & -0.2040 & 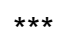 & 0.0710 & -0.0507 \\
\hline LANDINV & 0.0523 & & 0.1948 & 0.0130 \\
\hline FORESTER & -0.0513 & & 1.1089 & -0.0128 \\
\hline FRMP & 1.6241 & * & 1.0154 & 0.4037 \\
\hline Likelihood Ratio & $29.0511^{\star \star \star}$ & & & \\
\hline Chi-square value & 0.0064 & & & \\
\hline Obs correctly predicted & $79(77.4 \%)$ & & & \\
\hline Total no of observations & 102 & & & \\
\hline & 54 & & & \\
\hline & 48 & & & \\
\hline
\end{tabular}

* Significant at 10\% level, ** Significant at 5\% level, *** Significant at 1\% level 
Landowners with higher education were more likely to engage in silvicultural activities and their probability of engaging in silvicultural activities was $24.10 \%$ higher than the landowners who were not college graduates. Higher income also favored silvicultural activities. For example, landowners with an annual household income of $\$ 40,000$ to $\$ 60,000$ had a 7.69\% higher probability of engaging in some type of silvicultural activity than the landowners with an annual household income of $\$ 20,000$ to $\$ 40,000$. Contrary to the expectation, size of forestland ownership (LNFORAC) was found to be negatively associated with the probability to engage in silvicultural activities. The marginal effect indicated that landowners with an additional 1 acre of forestland are $1.04 \%$ less likely to engage in silvicultural activities. Landowners who had purchased their forestland were however 23.67\% more likely to engage in silvicultural activities as compared to landowners who had acquired their forestlands by other means. The landowners who had owned their forestland with the primary objective of timber sale were also more likely to engage in silvicultural activities. Landowners with the non-timber objectives also had a higher probability of engaging in silvicultural activities.

\section{PROPERTY}

Results of the logit model are presented in Table 4.6. Only 102 respondents were used in estimating the model parameters. Majority of the respondents (52\%) had conducted some form of property management activities (road construction, road maintenance, survey/boundary maintenance, and access control) either in 2004 and/or prior to 2004.

The model fit was significant at $1 \%$ level. The model correctly predicted $83 \%$ of the observations (84 out of 102). One variable representing the owner characteristics (INCOME), two variables representing ownership characteristics (YRACQ and PURCHASE), and three 
variables representing management characteristics (TIMBER, NONTIM, and LANDINV)

were significant.

Table 4. 6: Parameter estimates of the logit model that examines the factors affecting landowners' decision to engage in property management activities, West Virginia.

\begin{tabular}{|c|c|c|c|c|}
\hline Variable & Estimate & & Std Error & Marginal Effect \\
\hline Const & 2.8757 & & 2.1712 & \\
\hline AGE & -0.0154 & & 0.0281 & -0.0039 \\
\hline EDUC & 0.5506 & & 0.5830 & 0.1376 \\
\hline PROF & 0.4938 & & 0.6605 & 0.1234 \\
\hline INCOME & 0.3009 & * & 0.1815 & 0.0752 \\
\hline LNFORAC & 0.2344 & & 0.2225 & 0.0586 \\
\hline YRACQ & -0.0498 & $\star *$ & 0.0259 & -0.0124 \\
\hline DISTMILE & -0.0041 & & 0.0029 & -0.0010 \\
\hline PURCHASE & 1.1675 & ** & 0.5869 & 0.2919 \\
\hline TIMBER & -0.3932 & * & 0.2416 & -0.0983 \\
\hline NONTIM & -0.1583 & ** & 0.0743 & -0.0396 \\
\hline LANDINV & -0.5129 & ** & 0.2295 & -0.1282 \\
\hline FORESTER & 0.4324 & & 1.1544 & 0.1081 \\
\hline FRMP & 1.4318 & & 1.0482 & 0.3579 \\
\hline Likelihood Ratio & $39.1499^{\star \star \star}$ & & & \\
\hline Chi-square value & 0.0002 & & & \\
\hline Obs correctly predicted & $84(83 \%)$ & & & \\
\hline Total no of observations & 102 & & & \\
\hline & 53 & & & \\
\hline & 49 & & & \\
\hline
\end{tabular}

* Significant at $10 \%$ level, ${ }^{* *}$ Significant at $5 \%$ level, $* * *$ Significant at $1 \%$ level

Landowners with higher annual household income were found to be more likely to engage in property management activities. For example landowners with an annual household income of $\$ 60,000-\$ 80,000$ were $7.52 \%$ more likely to engage in property management activities as compared to landowners with an annual household income of $\$ 40,000-\$ 60,000$. The ownership size was however not significant even though it has the positive sign as expected. Year of first parcel acquisition was another variable which had the sign contrary to the one expected. Marginal effect indicates that landowners who own the forestland for each additional year are $1.24 \%$ less likely to engage in property management activities. Also, landowners who had purchased their forestland were $29.19 \%$ more likely to engage in property management than the landowners who inherited the forestland or those 
who had been gifted the forestland. Finally, landowners driven by timber, nontimber, or land investment related objectives were also more likely to engage in property management activities.

\section{RECREATION}

Results of the logit model are presented in Table 4.6. Only 102 respondents were used in estimating the model parameters. Majority of the respondents (59\%) had not conducted any wildlife habitat management or recreational improvement activities either in 2004 or prior to 2004.

Table 4. 7: Parameter estimates of the Logit model that examines the factors affecting landowners' decision to engage in wildlife habitat management and recreational improvement activities, West Virginia.

\begin{tabular}{|c|c|c|c|c|}
\hline Variable & Estimate & & Std Error & Marginal Effect \\
\hline Const & 4.1404 & * & 2.3249 & \\
\hline AGE & -0.0499 & * & 0.0291 & -0.0108 \\
\hline EDUC & 0.8618 & & 0.5620 & 0.1864 \\
\hline PROF & -0.4399 & & 0.6660 & -0.0952 \\
\hline INCOME & 0.2010 & & 0.1888 & 0.0435 \\
\hline LNFORAC & -0.2570 & & 0.2207 & -0.0556 \\
\hline YRACQ & 0.0083 & & 0.0233 & 0.0018 \\
\hline DISTMILE & -0.0075 & ** & 0.0036 & -0.0016 \\
\hline PURCHASE & 0.4323 & & 0.5954 & 0.0935 \\
\hline TIMBER & -0.0943 & & 0.2365 & -0.0204 \\
\hline NONTIM & -0.2057 & 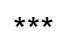 & 0.0761 & -0.0445 \\
\hline LANDINV & 0.3098 & & 0.2004 & 0.0670 \\
\hline FORESTER & 1.8830 & & 1.2759 & 0.4073 \\
\hline FRMP & -0.1750 & & 0.9547 & -0.0378 \\
\hline Likelihood Ratio & $28.9414^{\star \star \star}$ & & & \\
\hline Chi-square value & 0.0067 & & & \\
\hline Obs correctly predicted & $80(79 \%)$ & & & \\
\hline Total no of observations & 102 & & & \\
\hline & 42 & & & \\
\hline & 60 & & & \\
\hline
\end{tabular}

* Significant at $10 \%$ level, ${ }^{* *}$ Significant at $5 \%$ level, ${ }^{* * *}$ Significant at $1 \%$ level

The model fit was significant at $1 \%$ level. The model correctly predicted $79 \%$ of the observations (80 out of 102). One variable representing the owner (AGE) characteristics, one 
variable representing ownership (DISTMILE) characteristics and one variable representing management characteristics (NONTIM) were significant.

Age was inversely related to the decision to engage in habitat management and/or recreational improvement activities, which indicated that younger landowners were more likely to engage in habitat management and/or recreational improvement activities. The marginal effect also indicated that holding all the variables constant, a one year increase in age of the landowner is going to decrease the probability of engaging in habitat management and/or recreational improvement activities by $1.08 \%$. Landowners who resided farther from their forestland are less likely to engage in habitat management and/or recreational improvement activities. The marginal effect indicated that landowners who live an additional one mile away from their forest property are $0.16 \%$ less likely to engage in habitat management and/or recreational improvement activities. Finally, landowners driven by nontimber objectives are more likely to engage in habitat management and/or recreational improvement activities.

\subsection{Discussion}

Nonindustrial private forest landowners are a diverse set of individuals who own a significant proportion of the forestlands in the U.S. Understanding NIPF landowners' decisions regarding forest management will play a critical role in determining the nation’s future timber supply. This study looked at the factors that were associated with the forest management decisions of the NIPF landowners. The study looked at four models to identify the important factors in predicting the landowners' decisions to engage in four different categories of forest-related activities: timber harvest; silvicultural activities; property management activities; and habitat management and recreation improvement. Logit models 
were used to examine the relationship between landowners' decision to manage and a set of owner, ownership and management characteristics.

The results indicated that owner, ownership and management characteristics were important in interpreting the forest management decisions of the NIPF landowners. Results showed that silvicultural (46\%) and property management (47\%). activities were most frequent categories of activities that the NIPF respondents were engaged in. Wildlife habitat management and recreational improvement was the third most frequent category of activities that they engaged in (35\%) while timber harvesting was the least frequent of the four categories of forest management activities (28\%). Summing up, majority (59\%) of the landowners had undertaken some kind of forest management activity in their forest land in 2004 and/or prior to 2004.

For the model interpreting the harvesting decisions, age of the landowner, education, occupation as a professional, manager or white collar, period of forest acquisition, timber sale as a primary objective, and presence of a written forest management plan were found to be significant.

Age had a negative sign which meant that younger owners were more likely to engage in harvesting than older landowners. This finding contradicted with the results from Greene and Blatner (1986), Kuuluvainen et al. (1996) and Conway et al. (2003), which showed a positive relationship between age and the probability to harvest. However, a study by Romm et al. (1987) showed a negative association between forest investment and landowners older than 64 years. Further, Kuuluvanainen and Salo (1991) had shown a monotonic decrease in the rate of harvesting for the landowners from the youngest to the oldest age categories. Another possible reason for this is that older landowners are more 
likely to make bequest decisions about their property. According to Conway et al. (2003), age is a positive predictor of the probability to leave forestland as bequests. So the older the landowners, the more likely they are inclined to think of leaving the forestland for future generation resulting in minimal or no harvesting. The average age of the respondents was 59 years, so a majority of the respondents might not be inclined towards harvesting simply due to age.

Education was also a significant variable indicating higher education to be associated with higher probabilities of timber harvesting. Kuuluvainen et al. (1996) had shown education to be a positive predictor of the probability to harvest. Contrary to the expectation, landowners who were professionals, managers, or white collars were found to be less likely to harvest timber. This may be because people in this profession usually have higher income from sources other than timber- related. And so, landowners who are professionals, managers, or white collars may not be inclined towards the income received from harvesting timber. Period of forest acquisition was also a significant variable in landowners' forest harvesting decisions. The longer the landowners owned their forestlands, the more likely they are to harvest.

Timber sale as a primary objective was found to be significantly associated with the decision to harvest. This indicated that landowners with a primary objective of owning the forestland for timber sale are more likely to harvest timber than those who had other primary objectives. Landowners with a written forest management plan were also more likely to harvest than the landowners who do not have a written forest management plan. Baughman et al. (1998) also showed that presence of a written forest management plan encouraged landowners to harvest timber. 
For silvicultural activities, landowners' education, income, size of ownership, whether the land was purchased or acquired through other means, timber and nontimber benefits as primary objectives, and presence of a written forest management plan were significant.

Landowners with higher education were more likely to engage in silvicultural activities. Landowners with higher income were also more likely to engage in silvicultural activities. This may be due to the fact that landowners with higher income have more disposable income to invest in silvicultural activities. Previous studies have also found higher household income to be significant predictor of landowners engaging in silvicultural activities particularly, in reforestation (e.g., Cohen 1983, Royer 1985, Straka and Doolittle 1987, Hyberg and Holthausen 1983).

Ownership size was also a significant variable in the silviculture model however, contrary to the expectation, it was found to be negatively associated with the landowners engaging in silvicultural activities. This may be due to the fact that conducting silvicultural activities in smaller forestlands are more affordable to landowners. Since silvicultural expenses are variable costs, they may be too costly for larger tracts. While for fixed costs (e.g., property maintenance activities), it will be more cost-effective for larger tracts. Although not significant, the results of the property management model showed a positive sign for ownership size.

Landowners who had purchased their forestlands were more likely to engage in silviculture activities. Landowners who owned the forestland primarily for timber or nontimber related reasons were also more likely to engage in silviculture activities. This presents an encouraging scenario for the policy makers inclined towards increasing timber harvests 
from the private forestlands. Since multi-objective landowners have been found to harvest more frequently (e.g., Kuuluvainen et al. 1996, Karppinen 1998) motivating NIPF landowners towards multiple-use management can be one of the most effective ways to meet the objectives of both the NIPF landowners, already managing their forestland solely for nontimber benefits, and the policy makers. This can be achieved if and when landowners see that the programs offered better cater to reaching their primary objectives and at the same time opens up possibilities of financial return from timber sale as well. Finally, landowners who had a written forest management plan were also more likely to engage in silvicultural activities.

For property management activities, income, period of acquisition, whether the forestland had been purchased or acquired through inheritance or by other means, timber, non-timber and land investment as primary reasons for owning the land were significant.

Landowners with higher income were more likely to engage in property management activities. Ownership size was however not significant even though it had the expected sign. Period of forestland acquisition however had a negative sign, meaning that landowners who owned their forestlands for longer time period were less likely to engage in property management activities. This discrepancy might be attributed to the difference in the interests between the landowners who have recently acquired the property and those who have acquired it for a longer period of time. One of the first things that recent landowners may want to invest in their forestlands might very well be in property management (e.g., road construction, survey/boundary maintenance). 
The results also showed that landowners were more likely to engage in property management activities when their primary objectives were timber sale, nontimber benefits, or land investment related.

As for wildlife habitat management and recreational improvement, age, distance of the nearest forestland from the place of residence and nontimber benefits as the primary reason for owning the forestland were significant.

Younger landowners were found to be more likely to engage in wildlife habitat management and recreational improvement. Landowners who lived near their forestland were also more likely to engage in wildlife habitat management and recreational improvement activities. In addition, landowners with nontimber objectives were more likely to manage for wildlife and recreation.

The results showed that landowner, ownership and management characteristics were associated with the type of forest management activities the forest landowners were engaged in. The primary objective for owning the forestland, either timber related or nontimber related were the only two variables which were statistically significant across three different models and the sign of their coefficients were the same across all the four models. This suggested that forest landowners' objectives are important in determining the type of forest management activities they are engaged in. Landowners who thought timber to be an important reason for owning their property were more likely to harvest timber, engage in silvicultural activities, and/or property management activities. Similarly, landowners who thought nontimber benefits to be important then they were more likely to engage in silvicultural activities, property management activities, and/or wildlife habitat management or recreational improvement. 
Landowners' older age was found to be negatively associated with the probability to harvest and also with the probability to engage in wildlife habitat management or recreational improvement. Landowners who had higher education and had a written forest management plan were more likely to harvest timber and engage in silvicultural activities. Landowners who had higher income and had purchased their forestland were more likely to engage in silvicultural activities and property management activities.

Landowners who had acquired their forestland for longer period of time were more likely to harvest timber but were less likely to engage in property management activities. This finding suggests that landowners tend to engage in property management activities as one of the first activities after acquiring their forest properties. Timber production is a longterm activity and so timber is harvested at a later stage of forestland acquisition.

None of the variables had statistically significant coefficients for all four of the models. Seeking the help from a professional forester was the only variable that was not significant in any of the four models. This may have been due to the fact that only about $8 \%$ of the respondents had sought the help of a professional forester for managing their land.

The results of the study suggest that forest management decisions of the NIPF landowners are influenced by some of the landowner, ownership and management characteristics. Understanding the underlying decision factors of this diverse group of forest landowners might help in clearing the uncertainty towards predicting future timber supply. Thus, these factors could form the basis for developing, modifying and also for targeting the policy instruments to motivate the NIPF landowners in forest management. 


\section{CHAPTER V: SUMMARY AND CONCLUSIONS}

Nonindustrial private forest landowners play an important role in U.S. timber supply as they own about 49\% (363 million acres) of the nation's forestland (Birch 1996). This role is becoming even more important as the number of NIPF landowners continue to increase and at the same time regulations limit the timber supply from the public forestlands. The total number of individual NIPF landowners has increased from 9.3 million in 1994 to 10.3 million in 2002 (Butler and Leatherberry 2004). While the role of NIPF landowners in timber market increases, timber supply from NIPF lands in turn depends on the forest management and investment behavior of NIPF landowners. Thus, it is important to investigate forest management and investment behavior of NIPF landowners for designing policy instruments that will motivate landowners to engage in active forest management. This study examined the characteristics and forest management behavior of NIPF landowners of West Virginia. The study specifically included two analyses regarding the NIPF landowners' forest management decisions. The first analysis looked at the characteristics and forest management decisions of the NIPF landowners of West Virginia and the second analysis dealt with modeling the forest management decisions of nonindustrial private forest landowners of West Virginia.

The NIPF landowners of West Virginia mostly had small forestland holdings, with a median of 43 acres and with only a few parcels of land. Majority of the landowners had acquired their forestland within the period of 1950 and 2000. Only 24\% of the landowners reported any change in their forest area since acquisition of the property.

The landowners valued their land primarily for the non timber amenities rather than for timber sale. Aesthetics, residence, recreation and hunting ranked high for owning the 
forest land. Timber was a primary objective for only about $7 \%$ of them. However landowners with timber as a primary objective owned $97 \%$ of the total forestland reported by the respondents.

Most of the landowners managed their forest lands on their own. Only $8 \%$ of the landowners sought any professional help and $17 \%$ of the landowners had no one to manage their forest land. Only $12 \%$ of the landowners had a written forest management plan, however around 39\% of the landowners who did not have a written forest management plan were interested in having one. More than half of the respondents think that taxes do not influence their decision related to their forest property. About $17 \%$ of the landowners considered that taxes made them think of selling the property or breaking the forestland into smaller parcels or discourage forest management activities. Of the different types of taxes that landowners have to pay related to their forest property, property tax was thought to be the major tax type that influenced their forest management decisions. NIPF landowners paid an average of $\$ 2.11$ per acre of property tax in 2004 .

Participation of the landowners in forest management activities was low. Only about $32 \%$ of the landowners carried out any kind of forest management activities in 2004. However 59\% of the landowners had carried out some type of management activity in their forestlands in 2004 or prior to 2004. This might mean that landowners invest in forest management activities for reasons other than for timber management alone, given fewer percentages of landowners harvesting timber.

Harvesting of timber was carried out by only $21 \%$ of the landowners in between 2000 and 2004. But the prospect of future harvest seemed to improve as 34\% of the landowners had future plans to harvest. The lack of awareness and low participation of the NIPF 
landowners in the forestry assistance/incentive and educational programs seemed not a very encouraging scenario for the planners and the organizations who conduct such programs. Only $18 \%$ of the landowners participated in any forestry incentive/assistance programs and only $4 \%$ participated in the educations programs that are offered.

Most of the NIPF landowners were not a member of any forestry-related organizations. Approximately, $81 \%$ of the NIPF respondents were male, Caucasian and with an average age of 59 years. The majority of forest landowners were high school graduates and above and were mostly either professionals or retired. Majority of the landowners were from the middle income group (i.e., annual household income of $\$ 20,000-\$ 60,000$ ).

The second analysis investigated the forest management decisions of the NIPF landowners in West Virginia to see what owner (age, education, profession, and income) ownership (ownership size, period of first parcel acquisition, distance of the nearest parcel from the place of residence, and whether the forestland was acquired through purchase) and management characteristics (primary objective of owning the forestland was timber, nontimber benefits or land investment related, sought help from a professional forester in managing the forestland, and presence of a written forest management plan) were important in their decision making. Logit models were use to model the forest management decisions of the NIPF landowners. The forest management activities were categorized into four distinct categories (harvesting, silvicultural activities (tree planting, fertilization, herbicide application, grapevine control, thinning and timber stand improvement), property management activities (road construction, road maintenance, access control, and survey/boundary maintenance), and wildlife habitat management and recreation improvement. Four models were used to identify the important characteristics associated with 
the landowners' decision to engage in each of the four categories of forest management activities.

The results from the second analysis showed that owner, ownership, and management characteristics were associated with the decisions of the landowners to engage in forest management activities and also in the type of forest management activities that they carried out. For the harvest model, there were six significant variables: age of the landowner, education, occupation as a professional, manager or white collar, period of forest acquisition, timber sale as a primary objective, and presence of a written forest management plan.

Younger landowners were more likely to engage in harvesting than older landowners. Higher education was also associated with higher probabilities of timber harvesting. Landowners who were professionals, managers, or white collars on the other hand, were found to be less likely to harvest timber. Landowners who had owned their forestlands for a longer period of time were more likely to harvest. Landowners with a primary objective of owning the forestland for timber sale are more also likely to harvest timber.

For the silviculture model, there were seven significant variables: education, income, size of ownership, whether the land was purchased or been acquired through other means, timber and nontimber benefits as primary objectives, and presence of a written forest management plan.

Landowners with higher education and higher income were more likely to engage in silvicultural activities. Ownership size however, was found to be negatively associated with the landowners engaging in silvicultural activities.

Landowners who had purchased their forestlands were more likely to engage in silviculture activities. Landowners who owned the forestland primarily for timber or non- 
timber related reasons were also more likely to engage in silviculture activities. Finally, landowners who had a written forest management plan were also more likely to engage in silvicultural activities.

For property management model, there were six significant variables: income, period of acquisition, whether the forestland had been purchased or acquired through inheritance or by other means, timber, non-timber and land investment as primary reasons for owning the land.

Landowners with higher income were more likely to engage in property management activities. Period Landowners who owned their forestlands for longer time period however were less likely to engage in property management activities. Results also showed that landowners were more likely to engage in property management activities when their primary objectives were timber sale, nontimber benefits, or land investment related.

As for wildlife habitat management and recreational improvement model, there were three significant variables: age, distance of the nearest forestland from the place of residence and nontimber benefits as the primary reason for owning the forestland.

Younger landowners were found to be more likely to engage in wildlife habitat management and recreational improvement. Also, landowners who lived near their forest property and landowners with nontimber objectives were more likely to manage for wildlife and recreation.

The two analyses presented, characterized the NIPF landowners of West Virginia and identified the decision determinants of the landowners to engage in forest management activities using a set of owner, ownership and management characteristics. The models identified the factors affecting the decisions of landowners to engage in forest management 
activities. This knowledge can be important in developing policy instruments that will motivate the landowners’ group not already active in forest management activities.

While the majority of landowners did not harvest timber, most landowners conducted some type of forest management activity in their forestland. Thus, this presents an opportunity to motivate the landowner groups who are already engaged in silvicultural activities though not for timber, towards multiple-use management. Also majority of the landowners were found to be unaware of the various forestry educational and assistance/incentive programs, so being able to reach out to them effectively and creating awareness of these programs could very well be the missing link to an increase in the number of landowners engaging in forest management activities. Since the respondents reported meeting with a professional forester to be the most preferred way to learn about the forestry programs and practices, there is a need to increase the outreach of the professional foresters to the individual landowners. Also, conferences, workshops, and meetings targeted towards increasing the awareness of the NIPF landowners should focus on delivering programs covering a combination of their preferred topics (e.g., timber harvesting and sale, wildlife management, best management practices, insects and diseases). For example, educational programs that deals with the importance of engaging in silvicultural activities and timber harvesting as a way of controlling insects and diseases or for wildlife management might spark interest among larger population of landowners. Further, findings have also shown that landowners are interested in preparing forest management plans. Presence of written forest management plans are associated with increased forest management activity (Baughman et al. 1998). Thus easier reach to professional foresters and easier way to prepare forest management plans might induce more landowners in forest investment. 
While this study provides useful insight to the forest management decisions made by the NIPF landowners, the results might be biased due to the limited number of useful responses obtained from the survey. Follow up research could provide valuable information in this line and also validate the results of the study. Future researches could also consider integrating bequest motives of the NIPF landowners along with the market drivers like prices and interest rates into these models to provide accurate insights to the landowners' forest management decisions. Looking at the characterization of the landowners spatially could further provide site specific answers which could be very helpful in directing the policy instruments to motivate the landowners in active forest management. 


\section{References}

Adams, D.M., R.J. Alig, D.J. Anderson, J. Stevens, and J. Chmelik 1992. Future Prospects for western Washington's Timber Supply. University of Washington. College of Forest Resources, Institute of Forest Resources Contribution No. 74. Seattle, WA.

Adams, D.M., and R.J. Alig 1995. Productivity of Nonindustrial Private Forests in Western Washington: Alternative Futures. Western Journal of Applied Forestry 10(1):29-35.

Adams, D.M., R.W. Haynes, G.F. Dutrow, R.L. Barber, and J.M. Vasievich 2001. Private Investment in Forest Management and the Long-Term Supply of Timber, American Journal of Agricultural Economics 64(2): 232-241

Alig, R.J., D.M. Adams, J.R. Mills, and B.J. Butler. 2003. Private Forest Management and Investment in the US South: Alternative Future Scenario. Forest policy for private forestry: global and regional challenges. Teeter, L., Cashore, B., Zhang, D. 149-163.

Allison, P.D. 1999. Logistic Regression Using the SAS System: Theory and ApplicationJohn Wiley and Sons, 302p.

Amacher, G.S., M.C. Conway, and J. Sullivan 2003. Econometric analyses of nonindustrial forest landowners: Is there anything left to study? Journal of Forest Economics 9(2): 137-164.

Arano, K.G., T.L. Cushing, and I.A. Munn 2002. Forest Management Expenses of Mississippi's Non-industrial Private Forest Landowners. Southern Journal of Applied Forestry 26(2):93-98.

Arano, K.G. and I.A. Munn 2006. Evaluating forest management intensity: a comparison among major forest landowner types. Forest Policy and Economics 9(3):237-248.

Baughman, M.J., J. C. Cervantes, and D.M. Rathke 1998. Reaching Minnesota’s Nonindustrial Private Forest Landowners. P. 165-169 in Improving Forest Productivity for Timber: A key to Sustainability. Accessed on May 6, 2006 at: http://fr.cfans.umn.edu/publications/proceedings/papers/Baughman-Duluth.pdf

Bell, C.D., R.K. Roberts, B.C. English, and W.M. Park 1994. A Logit Analysis of Participation in Tennessee's Forest Stewardship Program. Journal of Agricultural and Applied Economics 26(2):463-472.

Belin, D.L., D.B. Kittredge, T.H. Stevens, D.C. Dennis, C.M. Schweik, and B.J. Morzuch 2005. Assessing Private Forest Owner Attitudes Toward Ecosystem-Based Management. Journal of Forestry 103(1):28-35.

Binkley, C. S. 1981. Timber Supply From Private Nonindustrial Forests, Bulletin No. 92, New Haven, CT: Yale University School of Forestry and Environmental Studies. 
Birch, T. W., and N.P. Kingsley 1978. The forest-land owners of West Virginia. USDA Forest Service resource Bulletin. NE-58:76p.

Birch, T.W. 1996. Private Forest Landowners of the United States (1994). USDA Forest Service, Northeastern Forest Experiment Station, Research Bulletin. NE-134. 183p.

Birch, T. W. 1997. Private Forest Landowners of the Central Hardwood Forest (1994). USDA Forest Service, Northeastern Forest Experiment Station, Research Bulletin. NE-188: 89-97.

Bliss, J.C. and M.J. Grassl 1987. Predicting Timber Harvests on Private Forests in Southwest Wisconsin. Northern Journal of Applied Forestry. 4:152-54.

Bliss, J.C., A. F. Martin 1989. Identifying the NIPF management motivations with qualitative methods. Forest Science 35(2):601-622.

Bliss, J.C., A. Martin 1990. How tree farmers view management incentives. Journal of Forestry 88(8):23-42.

Bliss, J.C., S. Nepal, R. Brooks Jr., and M.D. Larsen, 1997. In the mainstream: Environmental Attitudes of Mid-South Forest Owners. Southern Journal of Applied Forestry 21(1): 37-43.

Brunson, M.W., D.T. Yarrow, S.D. Roberts, D.C. Guynn, and M.R. Kuhns. 1996. Nonindustrial Private Forest Owners and Ecosystem Management: Can They Work Together? Journal of Forestry 94(6):14-21.

Boyd, R.G. 1984. Government Support of Non-Industrial Production: The Case of Private Forests. Southern Economic Journal 51:89-107.

Butler, B.J., and Leatherberry, E.C. 2004.America's Family Forest Owners. Journal of Forestry 102(7):4-9.

Childs, R.A. 2005. West Virginia's Forests: Growing West Virginia's Future. Bureau of Business and Economic Research, College of Business and Economics, West Virginia University.

Clawson, M. 1979. The Economics of U.S. Nonindustrial Private Forest Research Pb. No. R14, Resources for the Future, Washington, DC.

Cleaves, D.A. and M. Benett 1995. Timber Harvesting by Nonindustrial Private Forest Landowners in Western Oregon. Western Journal of Applied Forestry 10(2):66-71.

Cohen, M. A. 1983. Public Cost Share Programs and Private Investment in Forestry in the South. Non-industrial Private Forests: A Review of Economic and Policy Studies. Royer J. P., Risbrudt CD editors. Symposium proceedings Durham, North Carolina. April 1983. pp. 181-188. 
Conner, R.C. and A.J. Hatsell 2002. Forest Area and Conditions. In: Wear, D.N., John G. (EDs.), Southern Forest Resource Assessment. General Technical Report SRS-53. USDA Forest Service, Souther Research Station. Asheville, NC. 635p.

Conway, C. 1998. Effects of Shifting Populations and Preferences on Nonindustrial Landowner Behavior. M.S. Thesis Virginia Tech Department of Forestry, Blacksburg VA.

Conway, M.C., G.S. Amacher, and J. Sullivan 2003. Decisions nonindustrial forest landowners make: an empirical examination. Journal of Forest Economics 9(3): 181203.

Dennis, D. 1989. An economic analysis of harvest behavior: integrating forest and ownership characteristics. Forest Science 35(4):1088-1104.

DeSteiguer, J.E. 1984. Impact of Cost-Share programs on Private Reforestation Investment. Forest Science 40(3):697-704.

Dillman, D.A. 2000. Mail and Internet Surveys- The Tailored Design Method. John Wiley and Sons, New York. 464p.

Egan, A. 1997. From timber to forests and people: A view of non industrial private forest research. Northern Journal of Applied Forestry 14(4):189-93.

Egan, A., D. Gibson, , and R. Whipkey 2001. Evaluating the effectiveness of the forest stewardship program in West Virginia. Journal of Forestry 99(3): 31-36.

Egan, A.F., J. Rowe, D. Peterson, and G. Philippi 1997. West Virginia Tree Farmers and Consulting Foresters: A comparison of views on timber harvesting. Northern Journal of Applied Forestry 14(1): 16-19.

Elwood, N.E., E. N. Hansen. and P. Oester 2003. Management Plans and Oregon's NIPF Owners: A Survey of Attitudes and Practices. Western Journal of Applied Forestry 18(2): 127-132.

Erickson, D.L., R.L. Ryan, and R.D. Young 2002. Woodlots in the rural landscape: landowner motivations and management attitudes in a Michigan (USA) case study Landscape and Urban Planning 58: 101-112.

Finley, A.O., and D.B. Kittredge, Jr. 2006. Thoreau, Muir, and Jane Doe: Different Types of Private Forest Owners Need Different Kinds of Forest Management. Northern Journal of Applied Forestry 23(2006): 27-34.

Greene, J.L. and K.A. Blatner 1986. Identifying Woodland Owner Characteristics Associated with Timber Management. Forest Science 32(1): 135-146. 
Griffith, D.M. and R.H. Widmann 2003. Forest Statistics for West Virginia: 1989-2000. USDA Forest Service Northeastern Research Station Resource Bulletin NE-157. Accessed on August 6, 2006 at:

http://www.fs.fed.us/ne/newtown_square/publications/resource_bulletins/pdfs/2003/n e_rb157.pdf

Hardie, I. W. and P. J. Parks 1991. Individual Choice and Regional Acreage Response to Cost-Sharing Programs. Land Economics 72: 248-260.

Haymond, J.L. and K.A. Blatner 1988. NIPF Opinion Leaders: What do they want? Journal of Forestry 86(4):30-35.

Haynes, R., D. Adams, and J. Mills 1995. The 1993 RPA Timber Assessment Update. General Technical Report RM-GTR-229. Rocky Mountain Forest and Range Experiment Station, USDA Forest Service, Ft. Collins, CO. Accessed on August 6, 2006 at: http://www.fs.fed.us/pnw/pubs/rm_gtr259/GTR-RM-259aa.pdf

Haynes, R.W. 2002. Forest Management in the $21^{\text {st }}$ Century: Changing Numbers, Changing Context. Journal of Forestry 100(2): 38-43.

Henly, R.K., P.V. Ellefson, and M.J. Baughman 1990. Minnesota's Private Forest Management Assistance Program: An Evaluation of Aspen Timber Sale Assistance. Northern Journal of Applied Forestry 7:31-34.

Henry, W.A. and J.C. Bliss 1994. Timber Harvesting, Regeneration, and Best Management Practices Among West Central Alabama NIPF Owners. Southern Journal of Applied Forestry 18(3): 116-121.

Hubbard, W., C. Latt, and A. Long 1998. Forest Terminology for Multiple-Use Management. University of Florida, Cooperative Extension Service, Institute of Food and Agricultural Sciences SS-FOR-11.

Hyberg B. T. and D. M. Holthausen 1989. The Behavior of Non-industrial Private Forest Landowners. Canadian Journal of Forest Research 19:1014-1023.

Jennings, B. M., and D. McGill 2005. Evaluating the Effectiveness of the Forest Stewardship Program in West Virginia: Ten-Year Assessment. Northern Journal of applied Forestry 22(4) 236-242.

Jin, S. and S.A. Sader 2006. Effects of forest ownership and change on forest harvest rates, types and trends in northern Maine 228:177-186.

Karppinen, H. 1998. Values and objectives of non-industrial private forest owners in Finland, Silva Fennica 32: 43-59.

Kurtz, W.B., G. Noweg, R. Moulton, and R. Alig. 1993. Retention and Condition of CostShared Plantations. Bulletin 464. University of Missouri, Agricultural Experiment Station, MO. 
Kuuluvainen, J., and J. Salo. 1991. Timber Supply and Life Cycle Harves of Nonindustrial Private Forest Owners: An Empirical Analysis of the Finnish Case. Forest Science 37(4):1011-1029.

Kuuluvainen, J, H. Karppinen, and V. Ovaskainen 1996. Landowner Objectives and Nonindustrial Private Timber Supply. Forest Science 42(3):300-309.

Lonnstedt, L. 1997. Non-industrial Private Forest Owners/ Decision Process: A Qualitative Study about Goals, Time Perspective, Opportunities and Alternatives. Sacdinavian Journal of Forest Resources 12: 302-310.

Lonnstedt, L., and J. Svensson. 2000a. Non-industrial Private Forest Owners' Risk Preferences. Scandinavian Journal of Forest Resources 15:651-660.

Lonnstedt, L., and J. Svensson. 2000b. Return and Risk in Timberland and Other Investment Alternatives for NIPF Owners. Scandinavian Journal of Forest Resources 15:661-669.

Magill, D. 2003. Assessing West Virginia's NIPF Owner Characteristics and Preferred Assistance Topics and Delivery Methods. USDA Forest Service General Technical Report - North Central Research Station.

Magill, D.J., D.W. McGill, and R.F. Fraser, 2004. Refining Outreach to Woodland Owners in West Virginia -Preferred Topics and Assistance Methods. Journal of Extension 42(4).

Manski, C. 1977. The Structure of Random Utility Models. Theory and Decisions 8:229-254.

McGill, D. W., C. D. Pierskalla, B. M. Jennings, S. T. Grushecky, and D. Lilly 2006. Landowner Satisfaction with Timber Harvesting on West Virginia Forest Stewardship Program Properties. Northern Journal of Applied Forestry 23(1): 6-10.

Nagubandi, V., K. T. McNamara, W. L. Hoover, and W. T. Mills, Jr. 1996. Program Participation Behavior of Nonindustrial Forest Landowners: A Probit Analysis. Journal of Agricultural and Applied Economics 28(2): 323-336.

National Atlas of the United States, 2006. Forest Resources of the United States. Accessed on April 9, 2006 at: http://nationalatlas.gov/articles/biology/a_forest.html.

Newman, D.H., and D.N. Wear, 1993. Production Economics or Private Forestry: A Comparison of Industrial and Nonindustrial Forest Owners" American Journal of Agricultural Economics 75: 674-684.

Rickenbach. M.G., D.B. Kittredge, D. Dennis, and T. Stevens 1998. Ecosystem Management Capturing the Concept for Woodland Owners. Journal of Forestry 96(4):18-24.

Rickenbach, M.G., R.P. Guries, D.L. Schmoldt 2006. Membership Matters: Comparing Members and Non-members of NIPF Owner Organizations in Southwest Wisconsin, USA. Forest Policy and Economics 8(1): 93-105 
Romm, J., Tuazon, R. and C. Washburn 1987. Relating Forestry Investment to the Characteristics of Nonindustrial Private Forestland Owners in Northern California. Forest Science 33(1): 197-209.

Royer, J.P. 1985. The Effects of Markets and Public Policies on the Reforestation Behavior of Southern Landowners. Southeastern Center of Forest Economics Research WP 12, Research Triangle Park, NC.

Smith, W.B. 1999. The US forest resource current situation. USDA Forest Service 1997 RPA Assessment of the Nation's Forest. Accessed on May 6, 2006 at: www.srsfia.usfs.msstate.edu/wo/review.htm

Smith, W.B., J.S. Vissage, D.R, Darr, and R.M. Sheffield 2000, Forest Resources of the United States, 1997: U.S. Department of Agriculture Forest Service, MN.

Straka, T. J., H.W. Wisdom, and J.E. Moak. 1984. Size of Forest Holding and Investment Behavior of Nonindustrial Private Owners. Journal of Forestry 82:495-496.

Straka, T. J. 1985. Nonindustrial private forest itmber output: a positive projection. Resource Management and Optimization 3(3):209-217.

Straka, T. J. and S. Doolittle 1988. Propensity of Nonindustrial Private Forest Landowners to Regenerate Following Harvest:Relationship to Socioeconomic Characteristics, Including innovativeness. Resource Management and Optimization 6(2):121-128.

Tornqvist, T. 1995. Inheritors of the woodlands. A sociological study of private, nonindustrial forest ownership, Rapport - Institutionen for Skog-Industri-Marknad Studier, Sveriges Lantbruksuniversitet. Issue 41:41-48p.

USDA Foreign Agriculture Service. 2007. World Market Update. Accessed on July 19, 2007 at: http://www.fas.usda.gov/ffpd/Newsroom/Wood\%20Market\%20Update.pdf.

USDA Forest Service. 2007. West Virginia: State and Private Forestry Fact Sheet. Accessed on February 12, 2007 at: http://www.na.fs.fed.us/ra/factsheets/wv_std.pdf.

USDA Forest Service. 1990. An Analysis of the Timber Situation in the United States: 19892040. General Technical Report RM-199. Rocky Mountain Forest and Range Experiment Station, USDA Forest Service, Ft. Collins, CO. Accessed on March 12, 2007 at: http://www.treesearch.fs.fed.us/pubs/20055

Uusivuori, J. 2002. Nonconstant Risk attitudes and Timber Harvesting. Forest Science 48(3): 459-470.

White, D.E. 1993. West Virginia’s Second Forest. Miscellaneous Publication- Agriculture and Forestry Experiment Station, West Virginia University.

Zhang, D. and Pearse, P.H. 1996. Differences in Silvicultural Investment Under Various Types of Forest Tenure in British Columbia. Forest Science 42(4):442-449. 
Zhang, D. and Flick, W.A. 2001. Sticks, Carrots, and Reforestation Investment. Land Economics 77(3):443-456. 


\section{Appendix A: Questionnaire}

Please answer all questions. If for any reason you do not want to answer a particular question, please leave it blank. If you wish to comment on any questions or be more specific about your answers, please feel free to use the space in the margins.

\section{Part I. Property Information}

1. How many parcels of forest land do you currently own in West Virginia?

If NONE, please return this questionnairein theenvel ope provided. Thank you.

2. What is the total size of your forest land ownership (total from all parcels)? Total acres in West Virginia

3. To the best of your ability, divide your total West Virginia forest land into the following categories:

Hardwood: $\quad$ acres
Majority of the trees are in hardwoods (examples: oak, maple, black cherry, yellow poplar)

Pine: acres

Majority of the trees are softwoods (examples: Virginia pine, white pine, red spruce)

Mixed: acres

Majority of the trees are hardwoods, but at least $25 \%$ of the trees are pines.

Non-typed: acres

Previously wooded but currently contains no live trees or seedlings.

4. What year did you acquire your first forest land property?

5. How did you acquire your forest land property?
$\square$ Inherit
$\square$ Purchase
$\square$ Gift
Other, please specify:

6. From which individual or group did you acquire your forest land?
$\square$ Family
$\square$ Forest Industry
$\square$ Investment group
Land developer
$\square$ other individual
$\square$ others, please specify:

7. Has there been a change in your forest land acreage since you first acquired it?

$\square$ Yes $\square$ No

If YES, please specify whether there was an increase or decrease in your timberland area:

$\square$ Increase $\square$ Decrease

8. What was the primary reason for the change in your forest land acreage?
$\square$ Sold
$\square$ Bequeathed or given away
$\square$ Other. Please specify:

9. To which individual or group have you sold or given away your forest land?
$\square$ Family
$\square$ Forest Industry
$\square$ Investment group
$\square$ Land developer
$\square$ Other individual
$\square$ other. Please specify:

10. How far is your place of residence from your forest land? miles

(If you have several parcels in different locations, please answer for the nearest parcel).

11. Is your place of residence located in West Virginia? $\square$ Yes $\square$ No, which State? 


\section{Part II. Landowner O bjectives}

12. What is your primary reason for owning your forest land?

13. On a scale of 1 (very important) to 4 (not important), please indicate the level of importance of the following reasons for owning your forest land.

\begin{tabular}{|c|c|c|c|c|}
\hline & \multicolumn{2}{|c|}{ Very Important } & & N ot important \\
\hline A. Timber for sale & 1 & 2 & 3 & 4 \\
\hline $\begin{array}{l}\text { B. Wood for personal use } \\
\text { (construction, firewood, etc.) }\end{array}$ & 1 & 2 & 3 & 4 \\
\hline C. Wildlife for hunting & 1 & 2 & 3 & 4 \\
\hline D. Recreation & 1 & 2 & 3 & 4 \\
\hline E. A esthetics & 1 & 2 & 3 & 4 \\
\hline F. Residence & 1 & 2 & 3 & 4 \\
\hline G. Land Investment & 1 & 2 & 3 & 4 \\
\hline H. Water Quality & 1 & 2 & 3 & 4 \\
\hline I. Non-timber forest products & 1 & 2 & 3 & 4 \\
\hline (maple syrup, Christmas tre & $\mathrm{ms}$, etc.) & & & \\
\hline
\end{tabular}

\section{Part III. Forest M anagement and Investment}

14. Who manages your forest land?

$\begin{array}{lll}\square \text { Self } & \square \text { Industrial Forester } & \square \text { State Forester } \\ \square \text { Consulting Forester } & \square \text { Other, Non-Professional } & \square \text { No one }\end{array}$

15. Do you currently have a written forest management plan? $\square$ Yes $\quad \square$ No

If YES, are you following prescribed treatments in your management plan? $\square$ Yes $\square$ No If N O, would you be interested in having a written forest management plan for your timberland property? $\square$ Yes $\square$ No

16. How do taxes affect the management and use of your timberland property? (check all that apply)

$\square$ Promote harvesting of mature timber

$\square$ Promote timber harvesting regardless of whether the timber is mature or not

$\square$ Make me think about selling the property

$\square$ Promote conversion of the property to other land uses (agriculture, real estate, etc.)

$\square$ Promote forest management activities

$\square$ Promote subdivision of the property into smaller tracts

$\square$ Discourage investments in forest management activities

$\square$ Have no influence whatsoever

$\square$ other. Please specify:

17. Which of the following tax programs have affected the management and use of your timberland property?

(check all that apply)

$\square$ Federal income tax

$\square$ Severance Tax

$\square$ State incometax $\square$ Capital gain tax $\square$ Estate tax $\square$ Inheritance tax $\square$ Property tax $\square$ Other. Please specify: 
18. How much were your total 2004 county property taxes on your forested land? \$

19. Have you had your forest land appraised? $\square$ Yes $\square$ No

If YES, what is the appraised value per acre?
$\square \$ 0-\$ 200 \quad \square \$ 201-\$ 400 \quad \square \$ 401-\$ 600 \quad \square \$ 601-\$ 800 \quad \square \$ 801-\$ 1000 \quad \square \$ 1000$ or more

If $\mathrm{No}$, what do you think is the value of your forest land?

$\square \$ 0-\$ 200 \square \$ 201-\$ 400 \quad \square \$ 401-\$ 600 \quad \square \$ 601-\$ 800 \quad \square \$ 801-\$ 1000 \quad \square \$ 1000$ or more

20. Have you had the timber in your property appraised? $\square$ Yes $\quad \square$ No

If YES, what is the appraised value per acre? $\square \$ 0-\$ 500 \quad \square \$ 501-\$ 1000 \quad \square \$ 1001-\$ 1500$

$\square \$ 1501-\$ 2000 \square \$ 2001-\$ 2500 \square \$ 2501-\$ 3000 \quad \square \$ 3000$ or more

If $\mathbf{N o}$, what do you think is the value of the timber in your property?

$\square$ Less than $\$ 500 \quad \square \$ 501-\$ 1000 \quad \square=01001-\$ 1500$

$\square \$ 2001-\$ 2500 \quad \square \$ 2501-\$ 3000 \quad \square \$ 3000$ or more

$\$ 1501-\$ 2000$

- How did you come up with this value? $\square$ Self $\square$ Help from a forester

$\square$ Help from a land appraiser $\square$ other. Please specify:

- Would you be interested in having your timber appraised? $\square$ Yes $\quad \square$ No

21. Do you consider timberland investment as more risky than other potential investments (bank savings account, certificate of deposit, stocks, bonds, mutual funds)? $\square$ Yes $\square$ No

22. What is the lowest interest rate (example: $5 \%, 6 \%$, etc.) you consider acceptable for each the following investments:

\begin{tabular}{|l|}
\hline A. Bank savings account \\
B. Stocks, bonds, and mutual funds \\
C. Certificate of Deposit (CD) \\
D. 20-year timberland investment \\
E. 40-year timberland investment \\
F. 60-year timberland investment \\
G. 80-year timberland investment \\
H. $>$ 100-year timberland investment
\end{tabular}

23. Which of the following problems do you typically encounter on your forest land property? (check all that apply)

$\square$ Timber theft

$\square$ Poaching

$\square$ Conflicts with neighbors

$\square$ Trash dumping

$\square$ Inadequate roads

$\square$ Trespassing

$\square$ Land use regulations and restrictions

$\square$ Invasive species, please specify:

$\square$ Too many deer

$\square$ Not having people who can work in the forest

$\square$ Wildfire

$\square$ Other. Please specify: 
24. Which of the following forest management practices have you conducted since acquiring your forest land property? For activities conducted in the past year (2004), please indicate the number of acres and associated expenses. Please provide your best estimate.

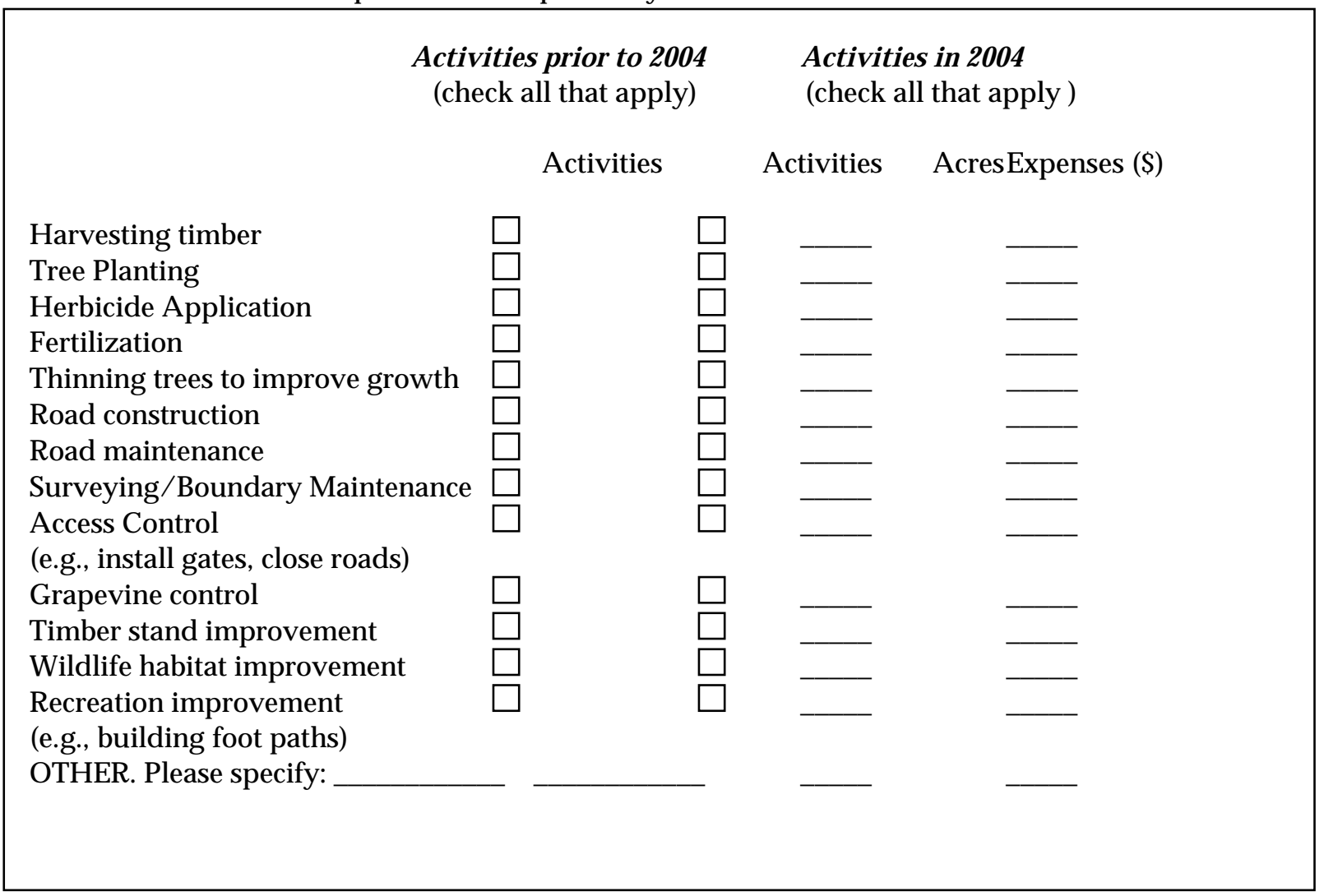

\section{Part IV. Harvesting and Sale}

25. Did you harvest or sell any timber or timber products from your forest land property in the last 5 years? $\square$ Yes $\square$ No

If YES, please continue to the next question. If N o, skip to Question \#32.

26. What were your primary reasons for harvesting or selling timber or timber products from your property?

(check all that apply)

$\square$ Good prices for timber

$\square$ Timber was mature

$\square$ Needed immediate cash

$\square$ A pproached by a timber buyer, forester or logger

$\square$ Salvaged the value of timber or timber products that have been damaged

$\square$ Conversion of timberland to other land uses (e.g., crop, pasture, golf, homesite)

$\square$ Improve quality of remaining trees

$\square$ Improve hunting opportunities

$\square$ Improve recreation opportunities

$\square$ Other. Please specify:

27. When was your most recent harvest/ sale? $\square 2000 \quad \square 2001 \quad \square 2002 \quad \square 2003 \quad \square 2004$ 
28. What harvest method was used in your most recent timber sale? Please provide an estimate of the acres harvested for the method used.

H arvest M ethod
$\square$ Diameter-limit cut
$\square$ Clear-cut
$\square$ select cut
$\square$ Others, please specify:

\section{A cres H arvested}

29. Do you know how much timber was harvested in your most recent harvest? $\square$ Yes $\square$ No If YES, please provide an estimate of the volume: MBF

30. Please report the total costs associated with you most recent the timber harvest: $\$$

31. Did you get advice or assistance from a professional forester during your most recent sale? $\square$ Yes $\square$ No

If YES,

- Which of the following professional forester type did you get advice or assistance from? (check all that apply)

$\square$ state forester $\square$ Industry forester $\square$ Extension forester $\square$ Federal government forester

$\square$ Consulting forester, please indicate total fee paid: \$ $\square$ Other. Please specify:

- How satisfied are you with the advice/ assistance you received?

$\square$ very satisfied $\square$ Somewhat satisfied $\square$ somewhat dissatisfied $\square$ Very dissatisfied

\section{Please proceed to Part IV, Question \#34.}

32. If you have not harvested or sold any timber or timber products in the last 5 years, what were the primary reasons? (check all that apply)

$\square$ Cut timber more than 5 years ago, none left $\square$ Prices were too low $\square$ Could not find a market $\square$ Unfamiliar with the buyers $\square$ Did not know what or how to sell $\square$ Not interested

$\square$ Extra income could increase income tax $\square$ Timber not mature enough $\square$ other:

33. Do you plan to harvest or sell any timber or timber products in the future? $\square$ Yes, when? $\_$No

\section{Part V. U se of Forestry A ssistance/Incentive and Educational Programs}

34. Have you attended any educational programs designed specifically for forest landowners that are conducted throughout West Virginia? $\square$ Yes $\square$ No

If YES,

- A bout how many of these programs have you attended in the last 5 years?

- How would you rate your level of satisfaction on these educational programs?
$\square$ Totally satisfied
$\square$ Satisfied
$\square$ Unsatisfied
$\square$ Totally unsatisfied

- Who sponsored or co-sponsored the educational programs that you attended?

$\square$ West Virginia University Extension Service $\square$ USDA Forest Service $\square$ West Virginia Forestry Association $\square$ West Virginia Division of Forestry $\square$ other:

35. Which of the following topics should be given focus in forestry educational programs? (check all that apply)

$\square$ Wildlife Management $\square$ Insects and Diseases $\square$ Timber Marketing

$\square$ Timber Harvesting and Sale $\square$ Best Management Practices $\square$ Forest Taxation

$\square$ Forest Valuation and Investment Analysis $\square$ Other, please specify: 
36. Which of the following learning tools would be most effective in delivering forestry educational materials?

$\square$ Conferences/ Workshops/ Meetings $\square$ Pamphlets/ Newsletter $\square$ Email/ Internet $\square$ Media (magazines, newspapers, radio, TV) $\square$ Video tapes/ CDs $\square$ Books

$\square$ Talking with a forester or extension agent $\square$ Field trips

37. Please indicate whether you are aware or have used any of the following forestry assistance/ incentive programs by checking the boxes in columns A and B. If you check any of the boxes in column B, please rate your level of satisfaction by encircling the appropriate number in column C.

\begin{tabular}{|c|c|c|c|c|c|c|c|}
\hline \multirow[b]{3}{*}{ A. Forest Stewardship Program } & $\begin{array}{l}\text { Column A } \\
\frac{\text { Amaware of }}{\text { program }}\end{array}$ & $\begin{array}{c}\text { Column B } \\
\text { Have used } \\
\underline{\text { program }}\end{array}$ & \multicolumn{5}{|c|}{$\begin{array}{l}\text { Column C } \\
\text { Satisfaction level } \\
\underline{\text { for the program }}\end{array}$} \\
\hline & & \multicolumn{3}{|c|}{ Very Satisfied } & \multicolumn{3}{|c|}{ Very D issatisfied } \\
\hline & $\square$ & $\square$ & 1 & 2 & 3 & 4 & 5 \\
\hline B. Forestry Incentive Program & $\square$ & $\square$ & 1 & 2 & 3 & 4 & 5 \\
\hline C. Conservation Reserve Program & $\square$ & $\square$ & 1 & 2 & 3 & 4 & 5 \\
\hline D. Forest Land Enhancement Prograr & $\square$ & $\square$ & 1 & 2 & 3 & 4 & 5 \\
\hline E. Federal Income Tax Incentives & $\square$ & $\square$ & 1 & 2 & 3 & 4 & 5 \\
\hline F. West Virginia's Managed & $\square$ & $\square$ & 1 & 2 & 3 & 4 & 5 \\
\hline G. Timberland Tax Incentive Progran & $\square$ & $\square$ & 1 & 2 & 3 & 4 & 5 \\
\hline
\end{tabular}

\section{Part VI. Demographics}

38. Do you belong to any forestry-related organization? $\quad \square$ Yes $\quad \square$ No

39. What is your age? years old

40. What is your gender? $\square$ Male $\square$ Female

41. What is your highest educational attainment?
$\square$ Elementary
$\square$ Some High School
$\square$ High School Graduate
$\square$ Some College
$\square$ College Graduate
Advanced Degree (M.S., M.A., M.B.A., Ph.D.)

42. Which of the following best describes your racial or ethnic background?
$\square$ Cauc Other:

43. Which of the following best describes your current occupation?

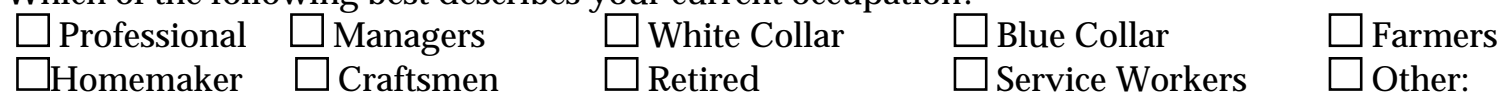

44. What is your approximate annual household income before taxes?
$\square$ Less than $\$ 20,000$
$\square \$ 60,001-\$ 80,000$
$\square \$ 20,001-\$ 40,000$
$\square \$ 40,001-\$ 60,000$
$\square \$ 80,001-\$ 100,000$
More than $\$ 100,000$ 
We appreciate your time and effort in completing this survey. Please feel free to write any other comments that you might have about this survey.

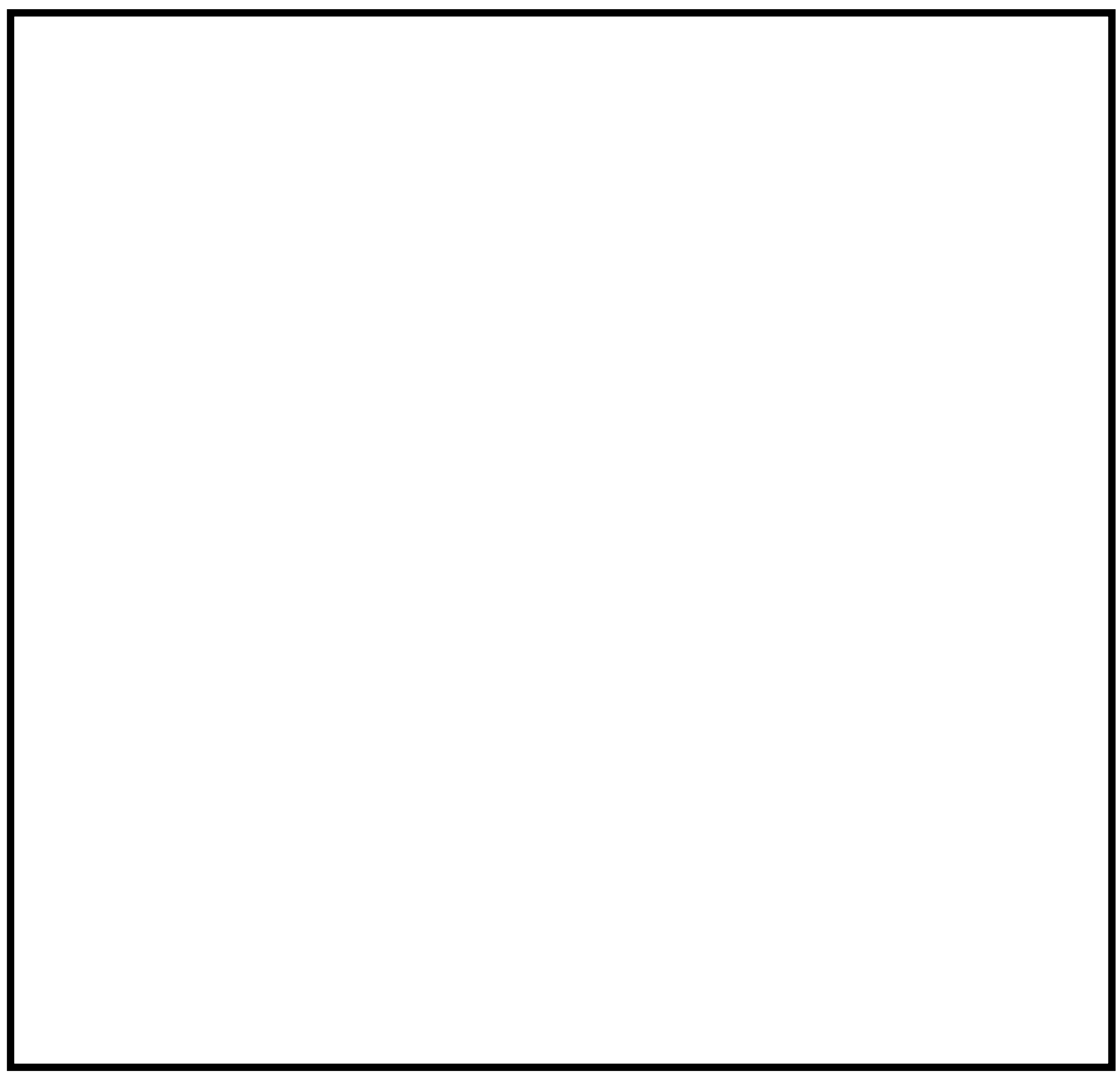

Thank you for you participation.

Please return the questionnaire in the postage-paid envelope provided. 


\section{Appendix B}

Table B.1 Correlation coefficients between the independent variables used in the models that examine the factors affecting landowners' decision to engage in forest management activities, West Virginia, 2000-2004.

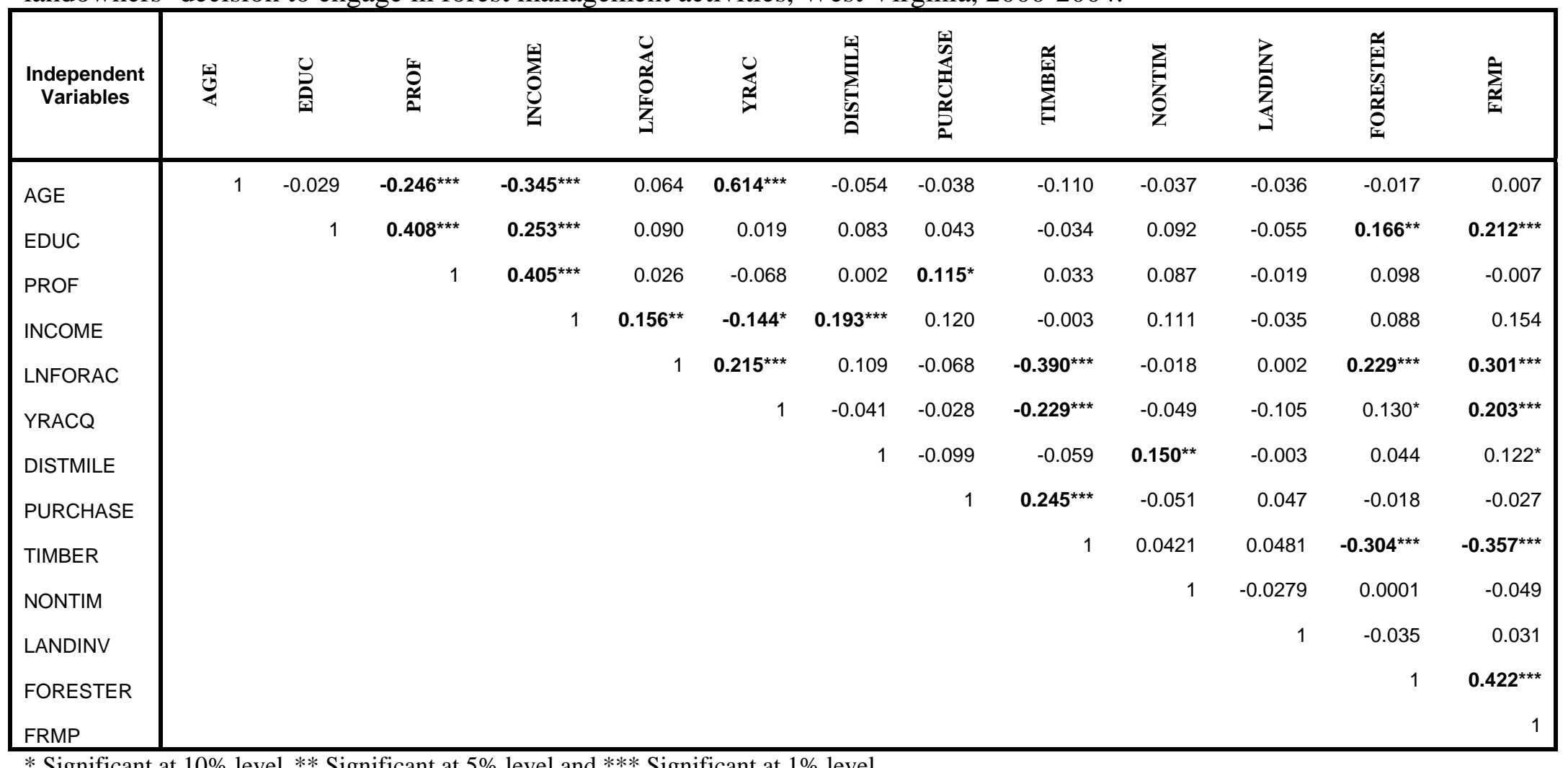

* Significant at $10 \%$ level, ${ }^{* *}$ Significant at $5 \%$ level and ${ }^{* * *}$ Significant at $1 \%$ level 


\section{Appendix C}

Table C.1 Parameter estimates of the four probit models examining the factors affecting NIPF landowners' decision to engage in four different categories of forest management activities, West Virginia ( $\mathrm{n}=244)$.

\begin{tabular}{|c|c|c|c|c|c|c|c|c|c|c|c|c|}
\hline \multirow[b]{2}{*}{ VARIABLE } & \multicolumn{3}{|c|}{ HARVEST } & \multicolumn{3}{|c|}{ SILVICULTURE } & \multicolumn{3}{|c|}{ PROPERTY } & \multicolumn{3}{|c|}{ RECREATION } \\
\hline & $\begin{array}{r}\text { Estimate } \\
\text { (Std. error) } \\
\end{array}$ & & $\begin{array}{r}\text { Marginal } \\
\text { Effect } \\
\end{array}$ & $\begin{array}{r}\text { Estimate } \\
\text { (Std. error) } \\
\end{array}$ & & $\begin{array}{r}\text { Marginal } \\
\text { Effect } \\
\end{array}$ & $\begin{array}{r}\text { Estimate } \\
\text { (Std. error) } \\
\end{array}$ & & $\begin{array}{r}\text { Marginal } \\
\text { Effect }\end{array}$ & $\begin{array}{r}\text { Estimate } \\
\text { (Std. error) } \\
\end{array}$ & & $\begin{array}{r}\text { Marginal } \\
\text { Effect }\end{array}$ \\
\hline \multirow[t]{2}{*}{ Const } & 2.6374 & $\star \star$ & & 3.3213 & 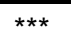 & & 1.8041 & & & 2.6541 & * & \\
\hline & (1.3033) & & & (1.3735) & & & $(1.2690)$ & & & $(1.3940)$ & & \\
\hline \multirow[t]{2}{*}{ AGE } & -0.0368 & $\star \star$ & -0.0113 & -0.0203 & & -0.0081 & -0.0107 & & -0.0043 & -0.0309 & * & -0.0111 \\
\hline & $(0.0165)$ & & & $(0.0167)$ & & & $(0.0165)$ & & & $(0.0176)$ & & \\
\hline \multirow[t]{2}{*}{ EDUC } & 0.9583 & * & 0.2930 & 0.6034 & * & 0.2398 & 0.3138 & & 0.1252 & 0.5179 & & 0.1852 \\
\hline & $(0.3472)$ & & & $(0.3303)$ & & & $(0.3433)$ & & & $(0.3331)$ & & \\
\hline \multirow[t]{2}{*}{ PROF } & -0.8068 & $\star \star$ & -0.2467 & -0.4837 & & -0.1922 & 0.3088 & & 0.1232 & -0.2642 & & -0.0945 \\
\hline & $(0.4167)$ & & & $(0.3746)$ & & & $(0.3844)$ & & & $(0.3981)$ & & \\
\hline \multirow[t]{2}{*}{ INCOME } & 0.0543 & & 0.0166 & 0.1821 & * & 0.0724 & 0.1754 & * & 0.0700 & 0.1205 & & 0.0431 \\
\hline & (0.1093) & & & (0.1059) & & & $(0.1061)$ & & & $(0.1129)$ & & \\
\hline \multirow[t]{2}{*}{ LNFORAC } & -0.1412 & & -0.0432 & -0.2479 & * & -0.0985 & 0.1385 & & 0.0553 & -0.1597 & & -0.0571 \\
\hline & $(0.1218)$ & & & $(0.1308)$ & & & $(0.1323)$ & & & $(0.1343)$ & & \\
\hline \multirow[t]{2}{*}{ YRACQ } & 0.0232 & * & 0.0071 & -0.0012 & & -0.0005 & -0.0279 & * & -0.0111 & 0.0051 & & 0.0018 \\
\hline & (0.0124) & & & $(0.0130)$ & & & (0.0149) & & & $(0.0141)$ & & \\
\hline \multirow[t]{2}{*}{ DISTMILE } & -0.0011 & & -0.0004 & -0.0003 & & -0.0001 & -0.0024 & & -0.0009 & -0.0044 & ** & -0.0016 \\
\hline & (0.0009) & & & $(0.0006)$ & & & (0.0016) & & & $(0.0021)$ & & \\
\hline \multirow[t]{2}{*}{ PURCHASE } & 0.0502 & & 0.0154 & 0.5888 & * & 0.2340 & 0.6934 & ** & 0.2766 & 0.2599 & & 0.0929 \\
\hline & $(0.3252)$ & & & $(0.3443)$ & & & $(0.3459)$ & & & $(0.3608)$ & & \\
\hline \multirow[t]{2}{*}{ TIMBER } & -0.3787 & 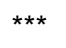 & -0.1158 & -0.3083 & $\star \star$ & -0.1225 & -0.2427 & * & -0.0968 & -0.0627 & & -0.0224 \\
\hline & (0.1338) & & & $(0.1486)$ & & & $(0.1434)$ & & & $(0.1429)$ & & \\
\hline \multirow[t]{2}{*}{ NONTIMBER } & -0.0314 & & -0.0096 & -0.1259 & $\star \star \star ~$ & -0.0500 & -0.0918 & ** & -0.0366 & -0.1292 & $\star \star \star$ & -0.0462 \\
\hline & $(0.0374)$ & & & $(0.0424)$ & & & $(0.0421)$ & & & $(0.0457)$ & & \\
\hline \multirow[t]{2}{*}{ LANDINV } & 0.0241 & & 0.0074 & 0.0164 & & 0.0065 & -0.3116 & ** & -0.1243 & 0.1783 & & 0.0637 \\
\hline & $(0.1182)$ & & & $(0.1154)$ & & & $(0.1316)$ & & & (0.1182) & & \\
\hline \multirow[t]{2}{*}{ FORESTER } & 0.0275 & & 0.0084 & -0.0523 & & -0.0208 & 0.2618 & & 0.1044 & 1.0835 & & 0.3874 \\
\hline & (0.5669) & & & $(0.6734)$ & & & $(0.6464)$ & & & $(0.7222)$ & & \\
\hline \multirow[t]{2}{*}{ FRMP } & 0.9357 & * & 0.2861 & 1.0129 & * & 0.4025 & 0.8697 & & 0.3469 & -0.1207 & & -0.0432 \\
\hline & $(0.5361)$ & & & $(0.6137)$ & & & (0.6290) & & & $(0.5836)$ & & \\
\hline
\end{tabular}

* Significant at $10 \%$ level, ** Significant at 5\% level and *** Significant at $1 \%$ level 


\section{SUDIKSHA JOSHI}

322 Percival Hall

P.O Box 6125

Morgantown, WV 26506-6125

Office: $304-293-2941 * 2310$

Home: 304-906-9023

sudikshajoshi@yahoo.com
125 Lorentz Street Apt\#3

Morgantown, WV 26505

\section{EDUCATION}

M. Sc. in Forest Resource Management (August 2005- August 2007)

Division of Forestry

West Virginia University

West Virginia

B.Sc. in Forestry (July 1999-August 2003)

Institute of Forestry, Pokhara Campus

Pokhara, Nepal

\section{EXPERIENCE}

Graduate Research Assistant (August 2005-till date)

Division of Forestry

West Virginia University

Major Responsibilities

- Collect and compile the data of the non industrial forest landowners of West Virginia for the year 2005 and 2006.

- Analyze and summarize the survey data collected from the landowners.

- Write papers on the findings for submission in conferences and journals.

Project Coordinator (September 2004-August 2005)

Namsaling Community Development Center (NCDC)

Ilam, Nepal

Major Responsibilities

- Coordinate the Collaborative Sustainable Development Planning Project (CSDPP), funded by the Development Fund, Norway.

- Coordinate with various local, national and international stakeholders.

- Conduct and facilitate workshops, seminars and trainings.

- Write reports and proposals for the organization.

- Supervise, monitor and evaluate the functioning of the project staff

Environment Officer (August 2003-August 2004)

Namsaling Community Development Center (NCDC)

Ilam, Nepal 


\section{Major Responsibilities}

- Coordinate with various local, national and international stakeholders.

- Conduct and facilitate workshops, seminars and trainings.

- Write reports and proposals for the organization.

- Conduct environmental awareness programs at the local and national level.

- Carry out bio physical assessment of the villages to incorporate in their sustainable development plans.

\section{PRESENTATION PAPERS}

- Joshi, S., Arano, K.G. 2007. "Forest Management Decisions of NonIndustrial Private Forest Landowners of West Virginia" Conference Paper submitted to SOFEW

- Joshi, S., Arano, K.G. 2005. "West Virginia Forest Landowners: A Look at Their Characteristics and Forest Management Decision" Conference Paper submitted to SOFEW.

- Joshi, S., "Biodiversity Conservation for Sustainable Development: A challenge"- A concept paper presented on the regional workshop conducted by NCDC, December 2003.

- Joshi, S., "Uncultivated Food Crops: Relevancy of Raising the Issue of Its Promotion in the Context of Ilam", A Discussion Paper presented in the Regional Workshop on "Uncultivated Food crops: Towards Food Security and Biodiversity Conservation" organized by NCDC, December 2004.

\section{UNPUBLISHED DOCUMENTS}

- Joshi, S., Chapagain, P., and Oli., K.P., "Developing a Transboundary Conservation Landscape for the Eastern Himalayas" for preparation of Participatory Biodiversity Conservation and Development Plans in 19 VDCs in the proposed biological corridors in Eastern Nepal", Study Report submitted to ICIMOD on behalf of NCDC, 2005.

- Joshi, S., "An Evaluation of Fund Mobilization in Royal Chitwan National Park Buffer Zone"- A Research paper funded by WWF, 2003

- Joshi, S., "An Assessment of Land Use Changes through Geographic Information System: A Case Study from Chhabdi Khola Sub-watershed of Tanahun District"- A Research Paper submitted for the partial fulfillment of the BSc Forestry degree, funded by NARMSAP, 2003 


\section{HONORS AND AWARDS}

- Research Assistantship for the Master's degree in Forest Resource Management in West Virginia University.

- Aishwarya Vidya Padak, a national award given to female students in Nepal for being the top female student in B.Sc. Forestry under the University.

- Stipend for being among the top 25\% students in each semester in B.Sc. Forestry.

- Full scholarship during the four years study of B.Sc. Forestry

\section{WORKSHOPS AND SEMINARS}

- Southern Forest Economics Workshop (SOFEW) in Knoxville, Tennessee, March 2006.

- A Regional Seminar on Sacred Himalayan Landscape, International Center for Integrated Mountain Development (ICIMOD), June, 2005.

- Asian Regional Seminar on Sustainable Education held in Dehradun, India, May 2005.

- Summer School of Youth Encounter on Sustainability (YES) conducted by Alliance for Global Sustainability (AGS) in Switzerland, July 2004.

- Asian Network for Alternative Cooperation (ANAC), workshop of a network of the Asian partners of the Development Fund, Norway December 2003.

\section{RESEARCH INTEREST}

Socio-economic analyses in trying to contribute to natural resource management, conservation and to rural and regional development. 